\title{
Aschives
}

CERN LIBRARIES, GENEVA

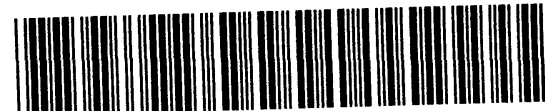

CM-P00062481

CERN-TH 6131/91

ISN $37 / 91$

\section{THE NON-RELATIVISTIC THREE-BODY PROBLEM FOR BARYONS}

\author{
Jean-Marc Richard \\ CERN, Theory Division \\ CH 1211 Genève 23 \\ and \\ Institut des Sciences Nucléaires \\ Université Joseph Fourier-CNRS-IN2P3 \\ 53 , avenue des Martyrs \\ F-38026 Grenoble Cedex
}

\begin{abstract}
The non-relativistic quark model, when applied to baryons, involves an interesting 3 -body problem where the constituents are bound by a confining potential. We review various possible methods which can be used for solving the 3 -quark problem accurately and discuss selected applications to baryon spectroscopy. We also present the state of the art on the rigorous properties concerning the level order of the 3-body spectrum, the dependence of the binding energy on the quark masses, and the inequalities relating the 3 -body to 2 -body binding energies.
\end{abstract}

CERN-TH 6131/91

August 12, 1991. 

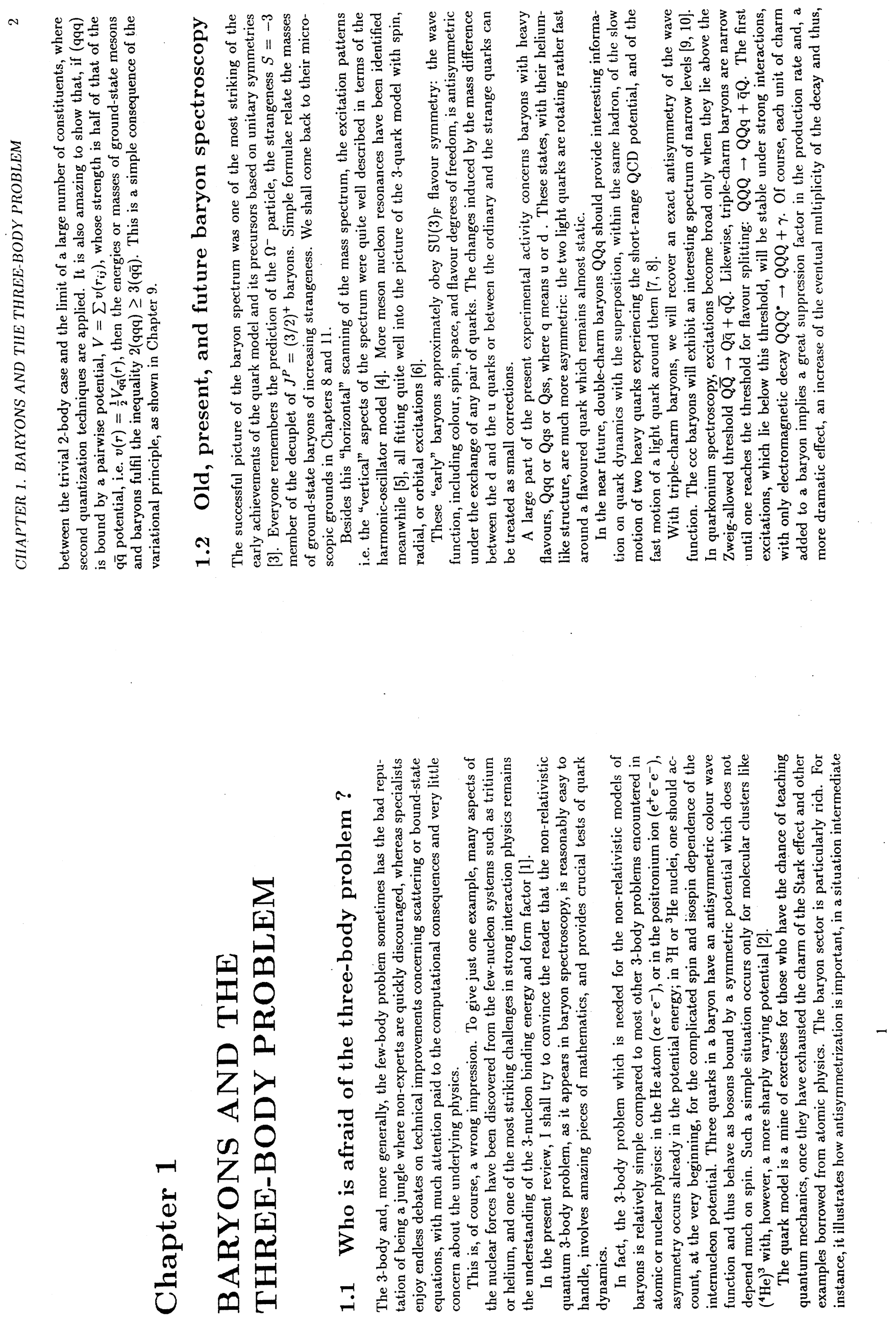


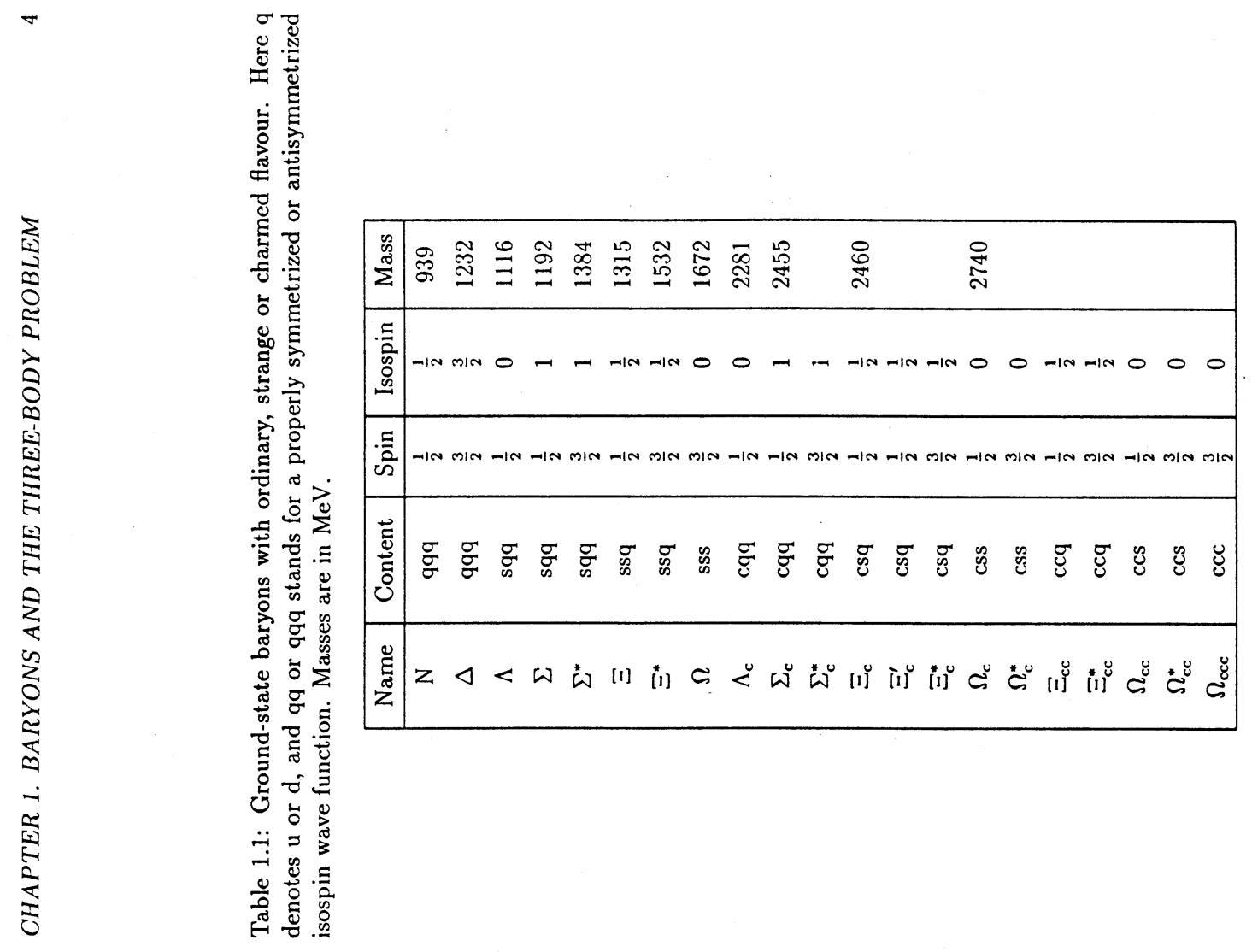

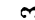

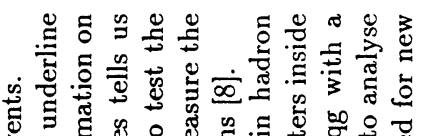

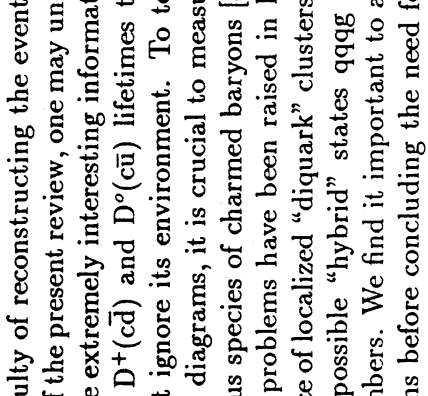

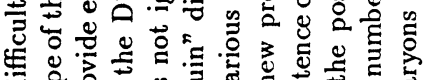

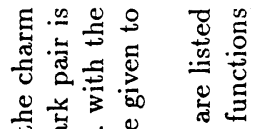

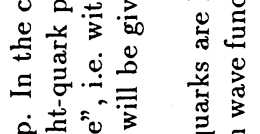

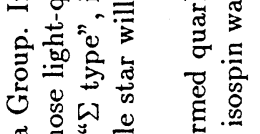

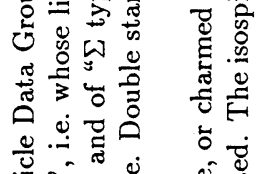

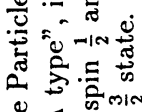
के

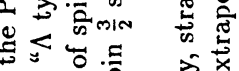

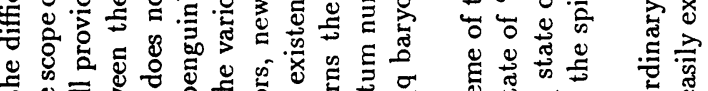

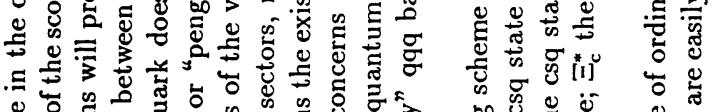

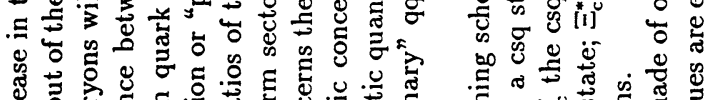

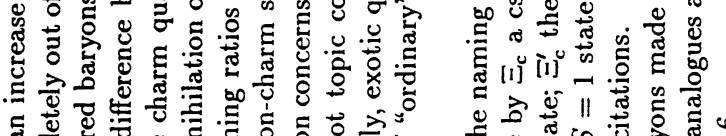

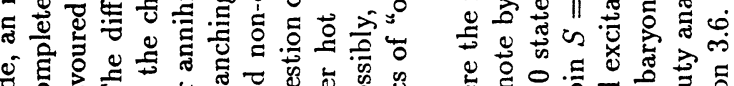

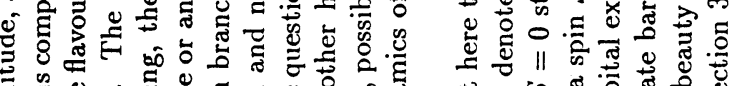

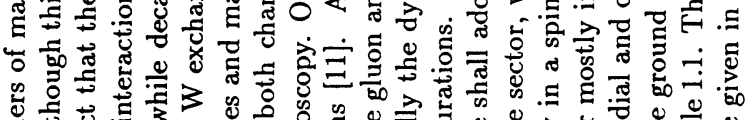

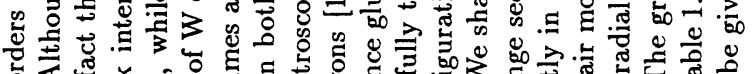

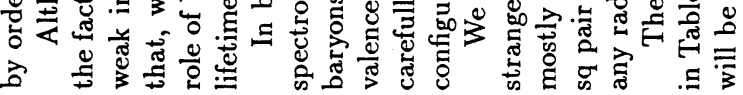

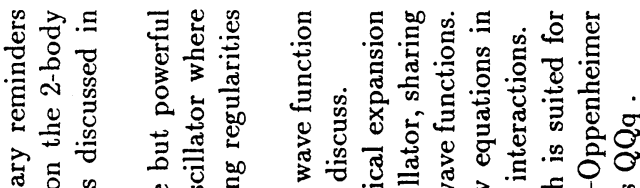

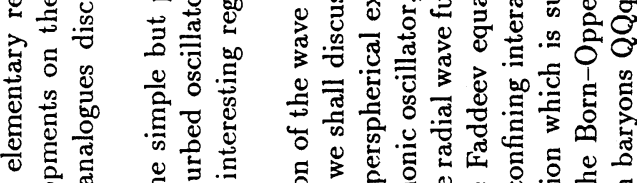

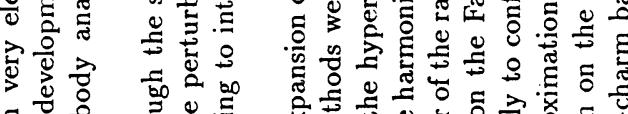

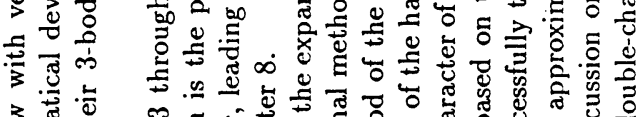

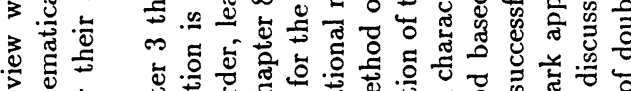

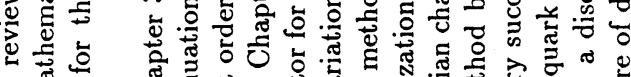

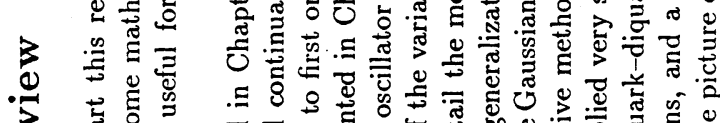

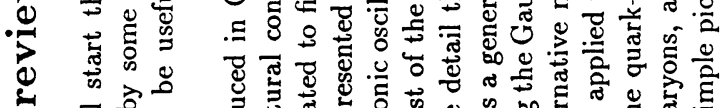

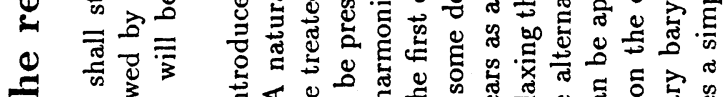

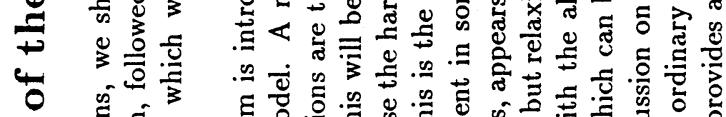

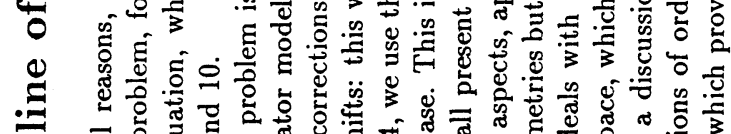

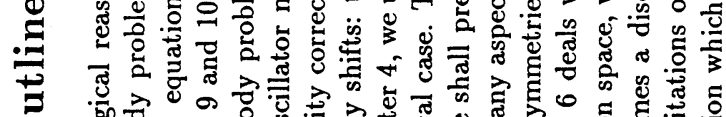

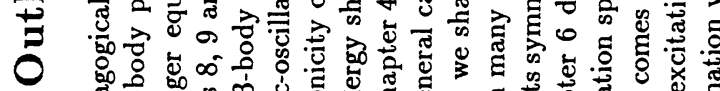

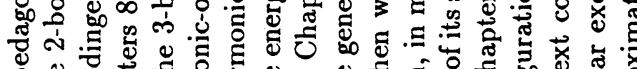

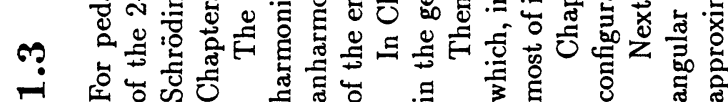



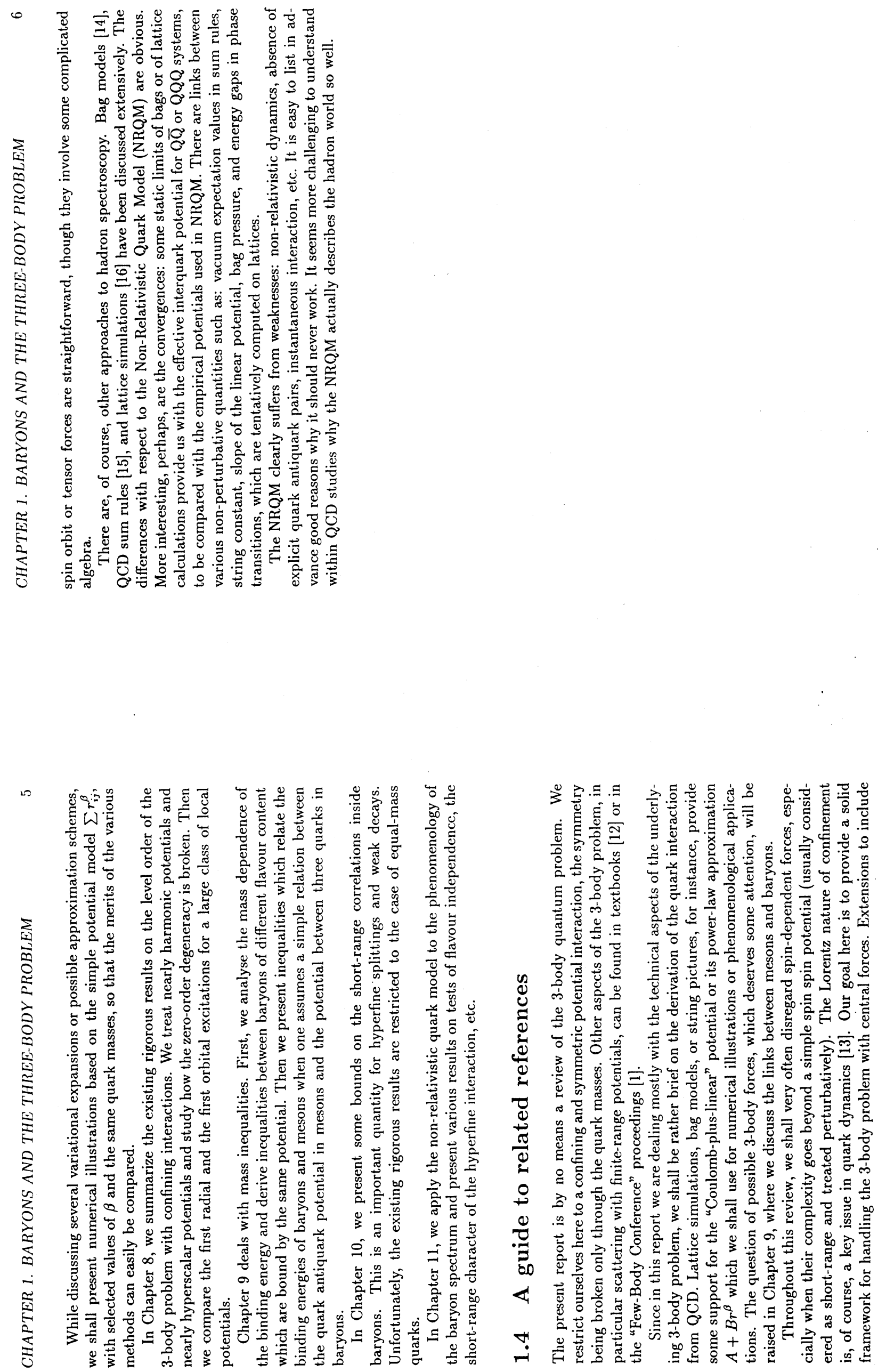

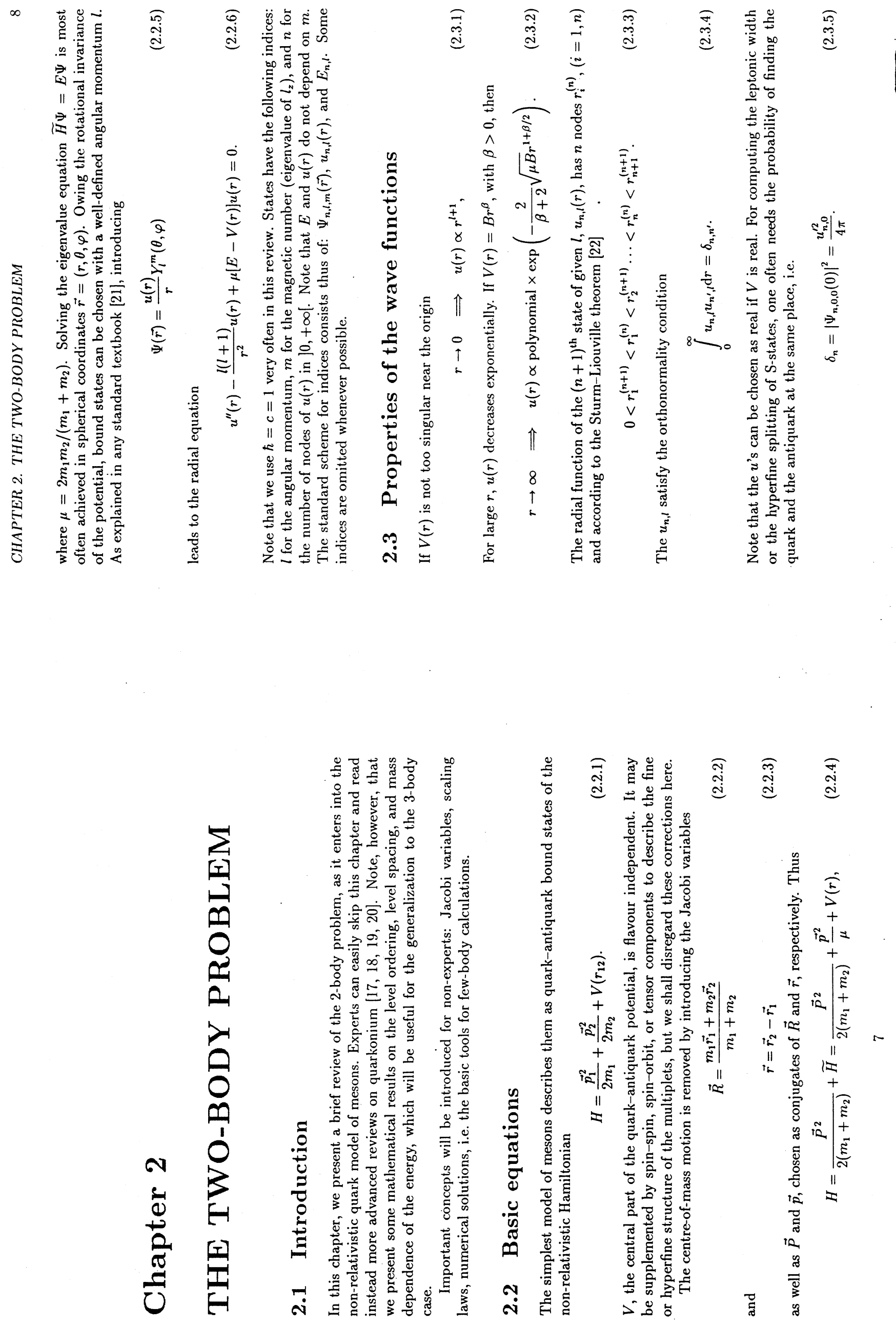

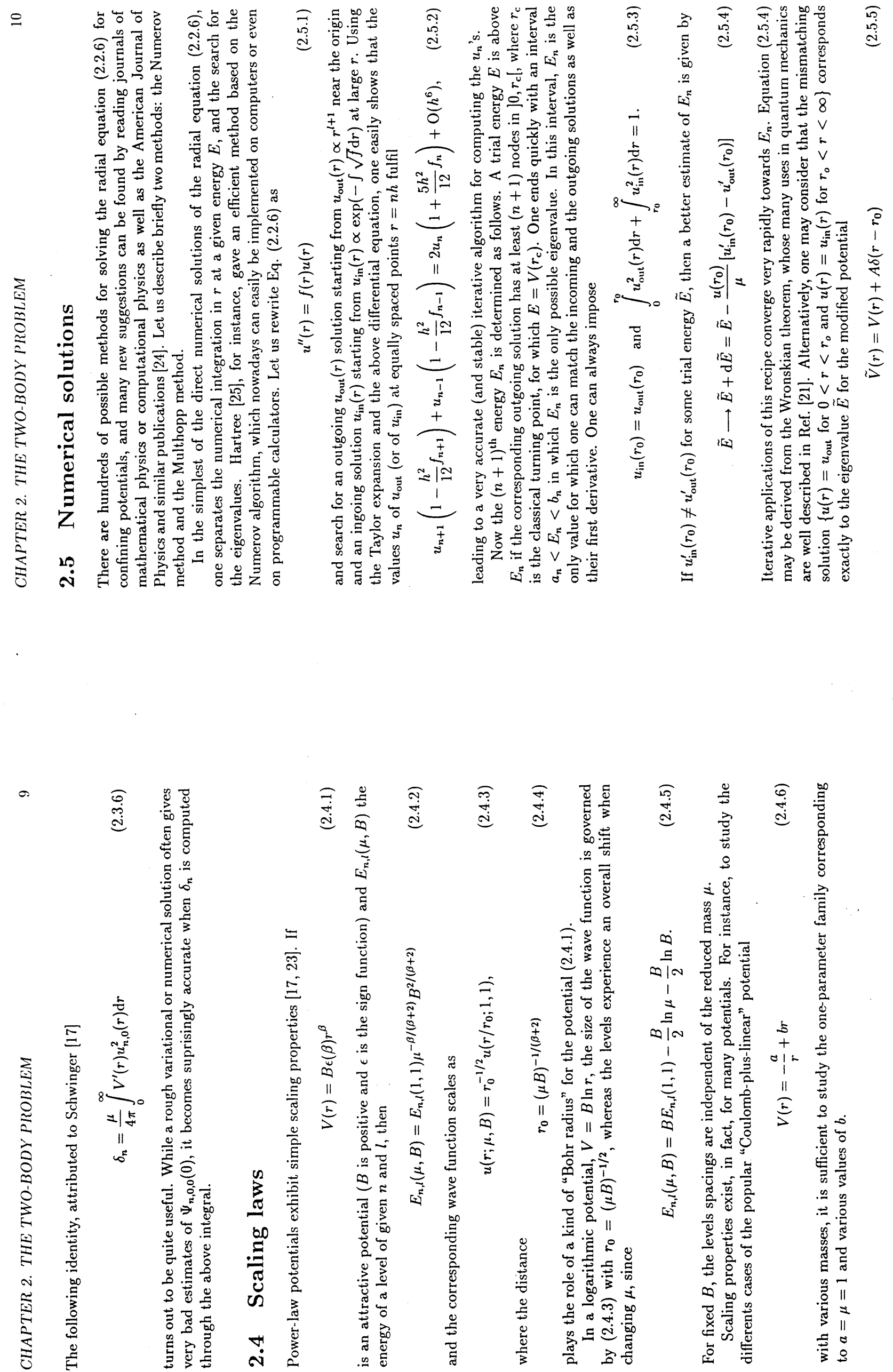

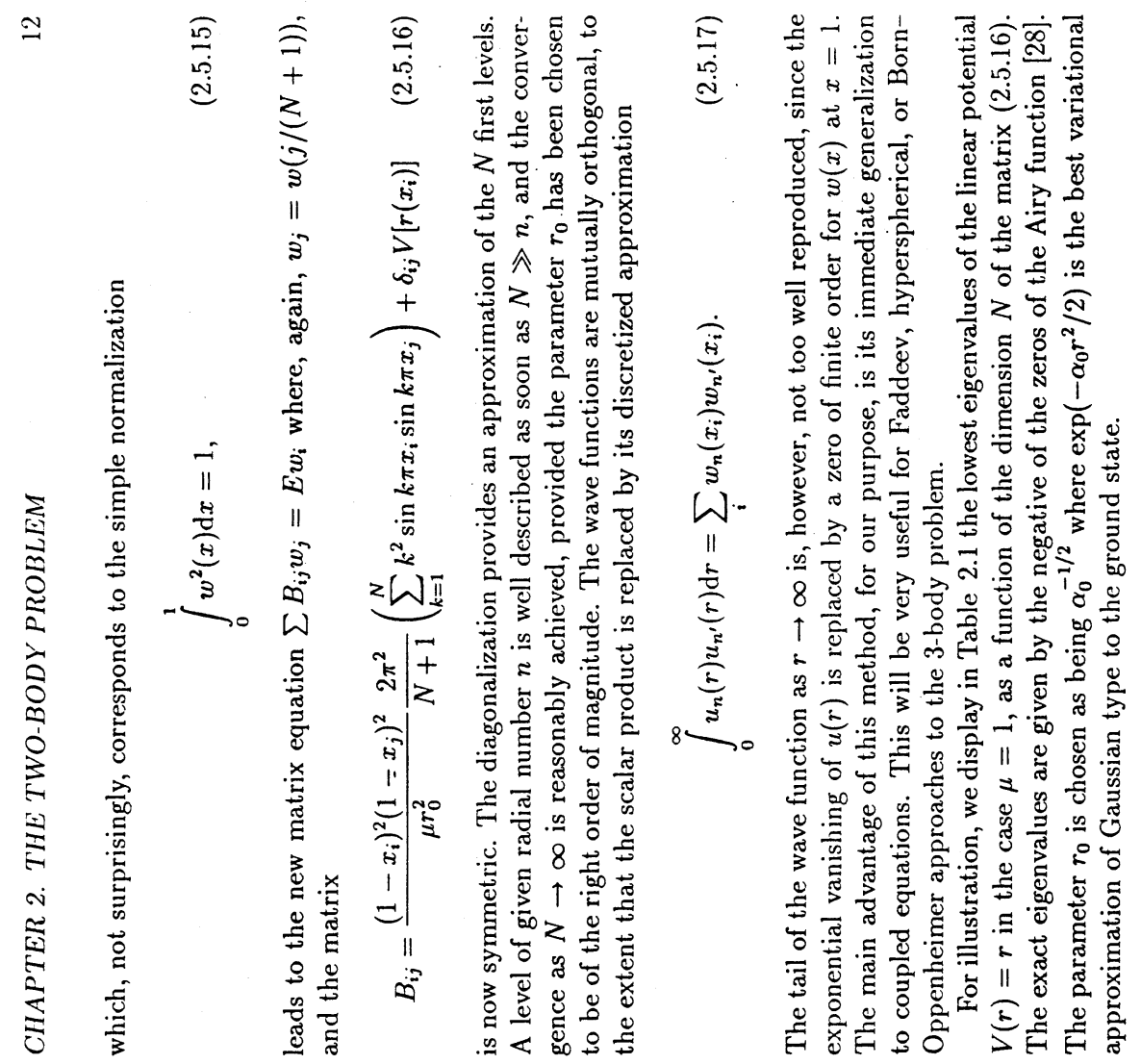

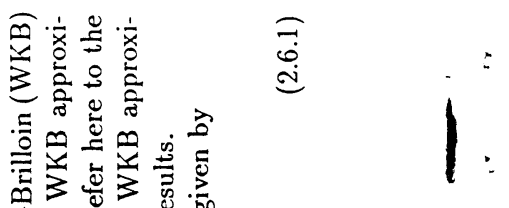

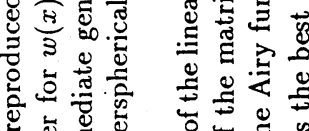

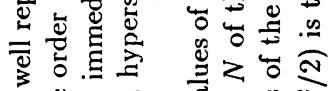

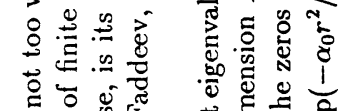

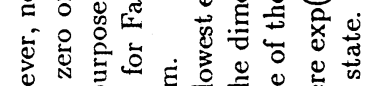

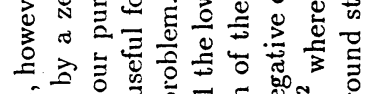

80

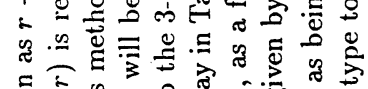

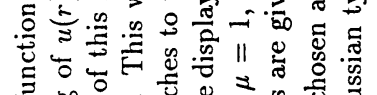

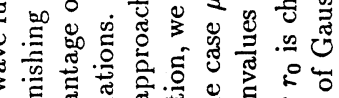

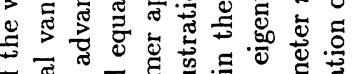

을

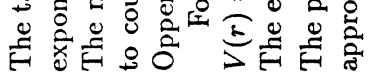

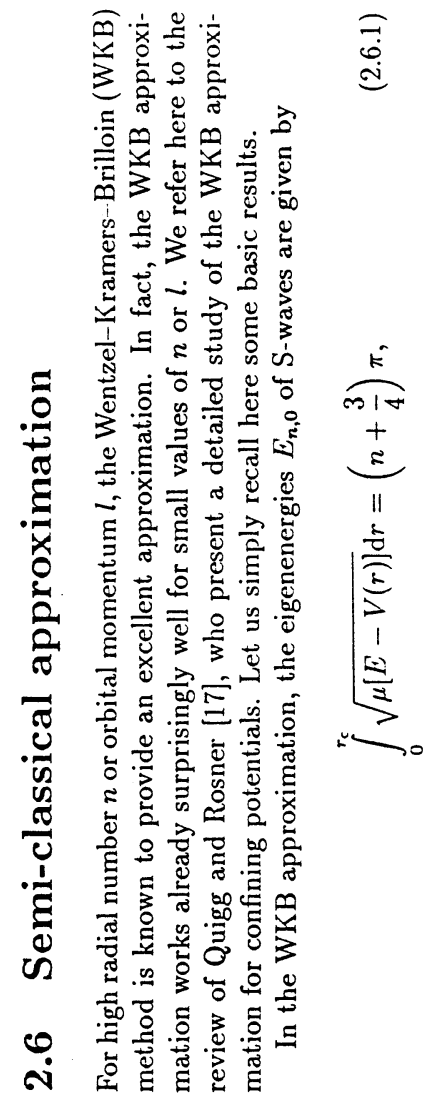

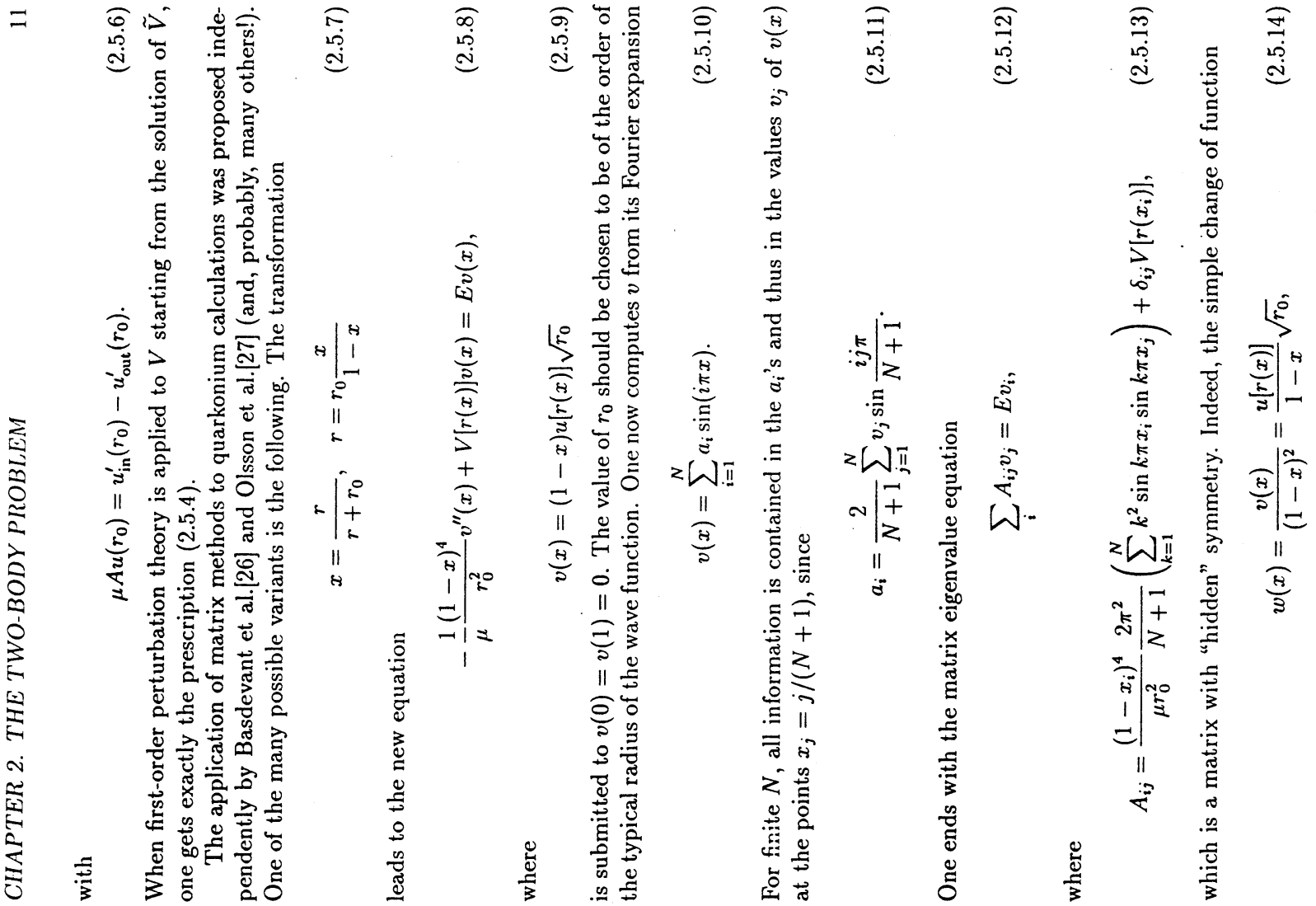



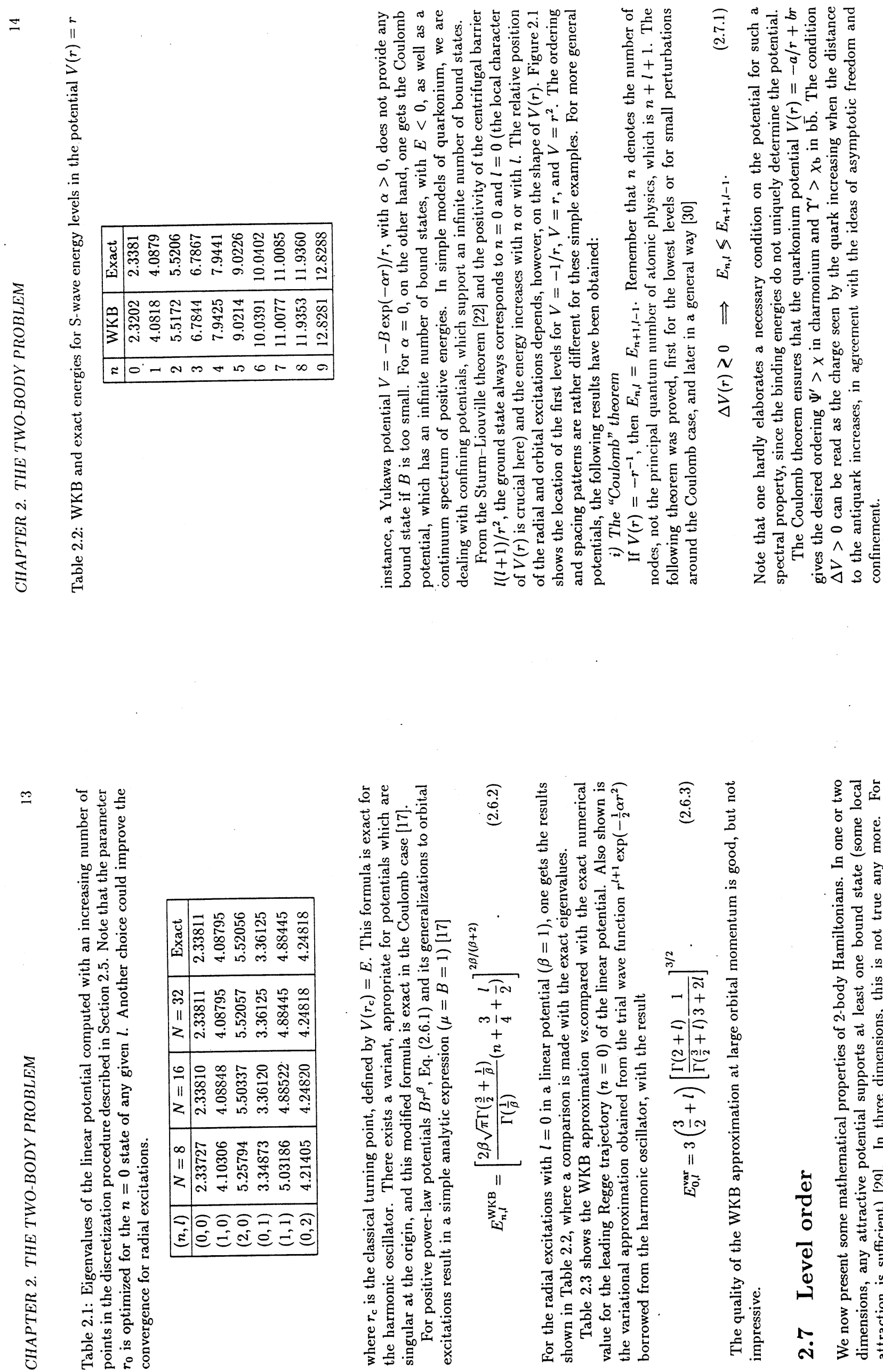

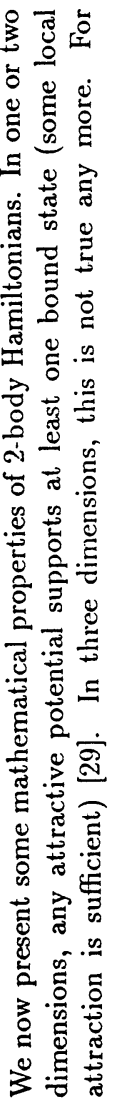



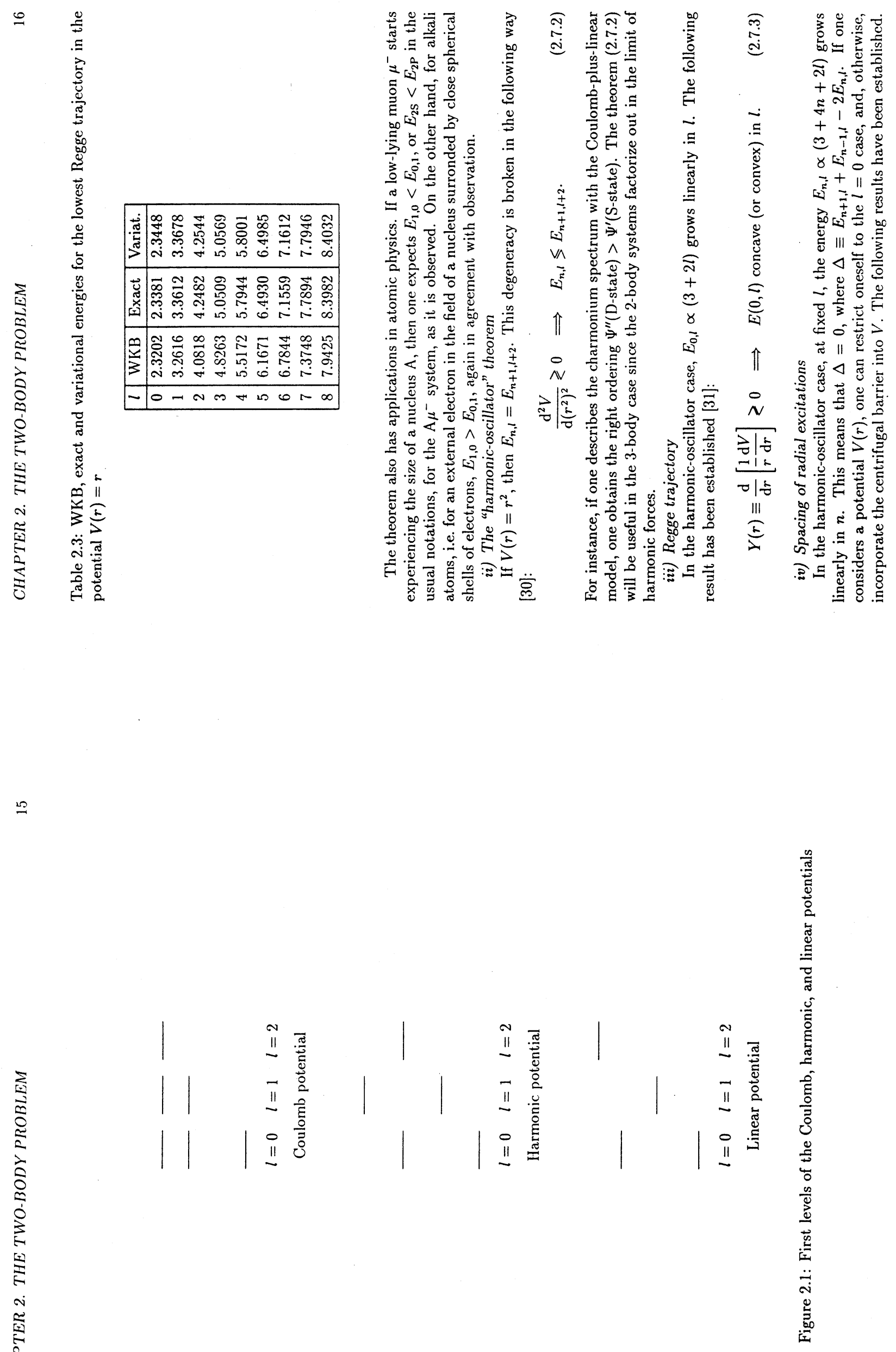

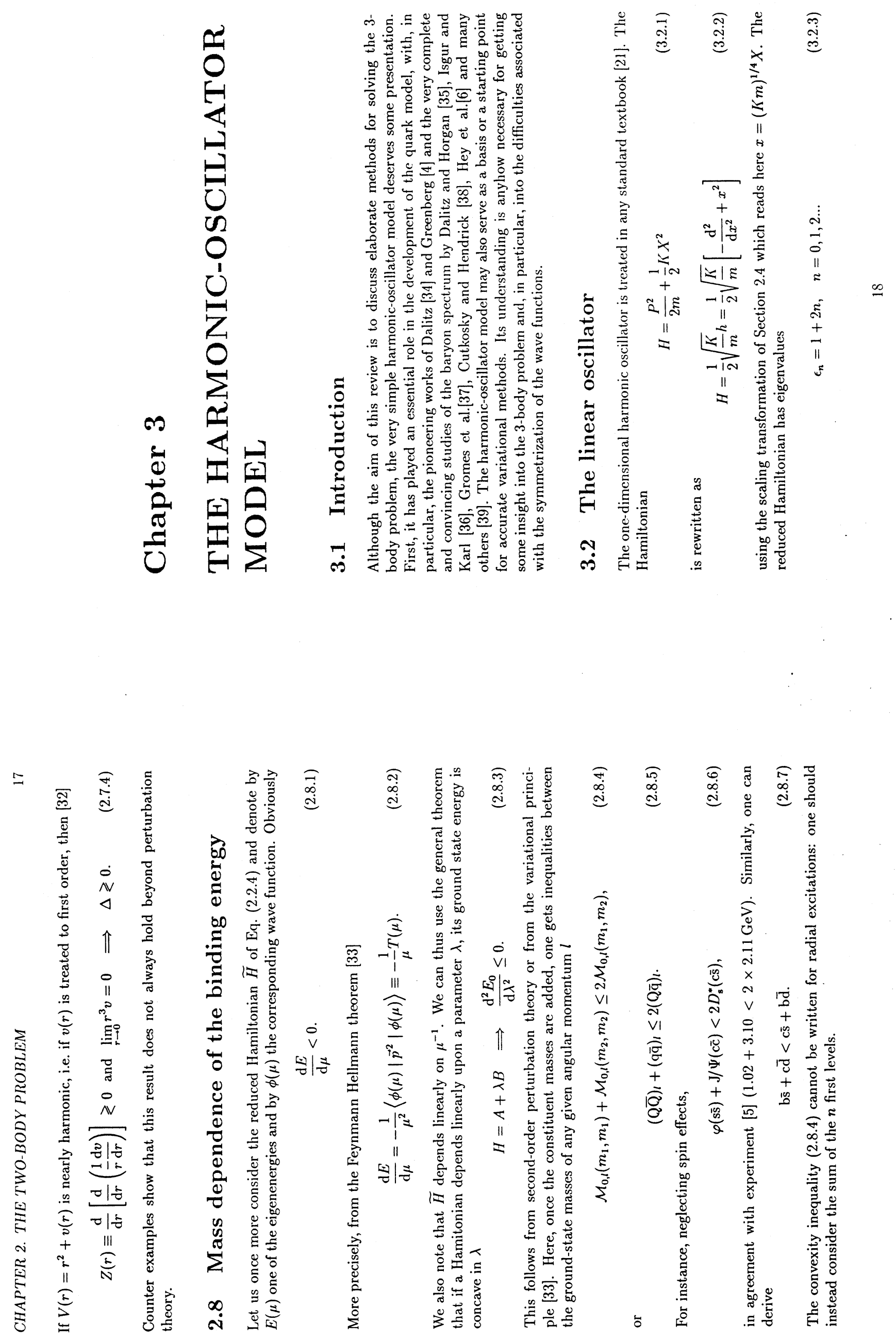


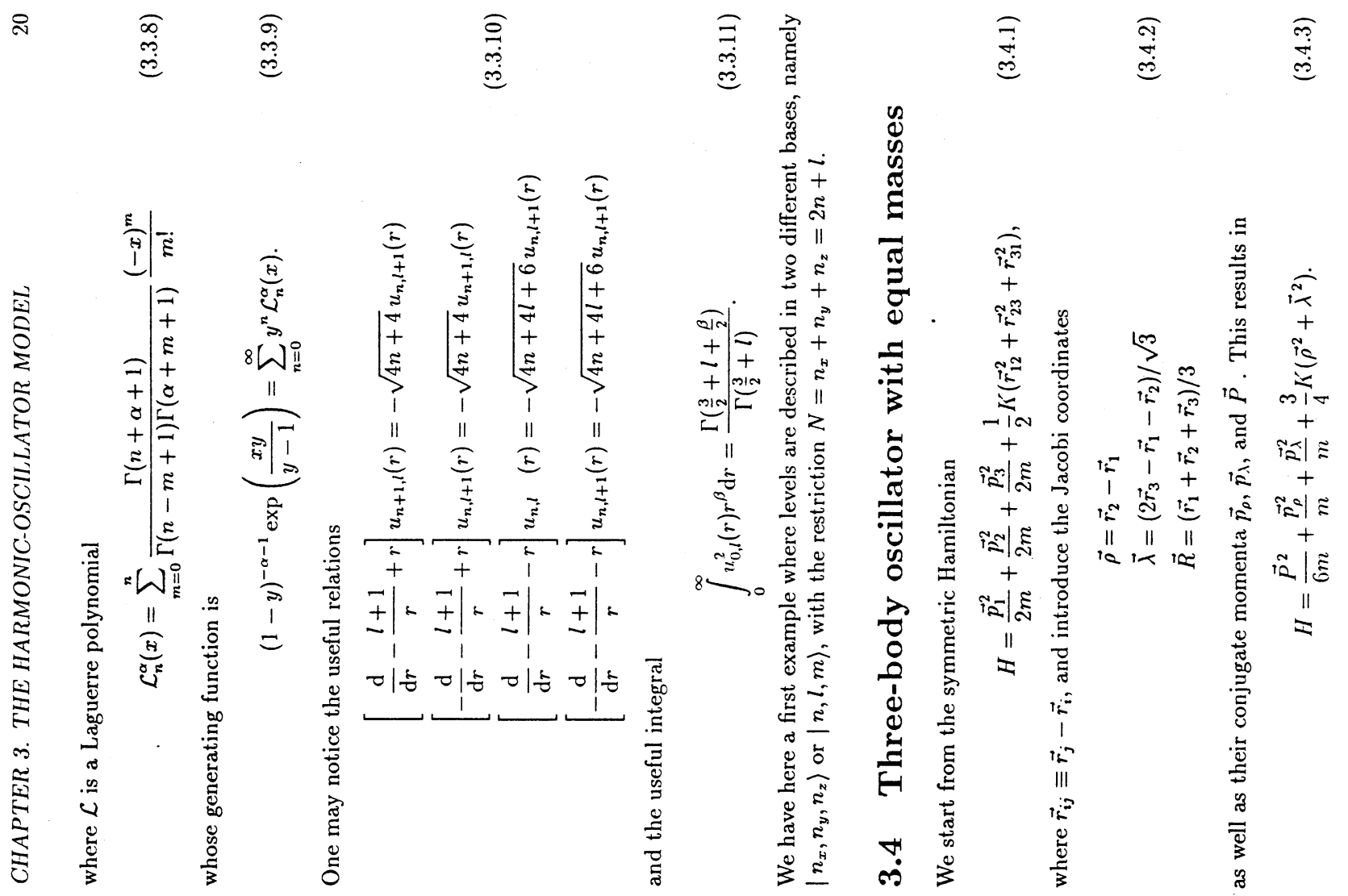

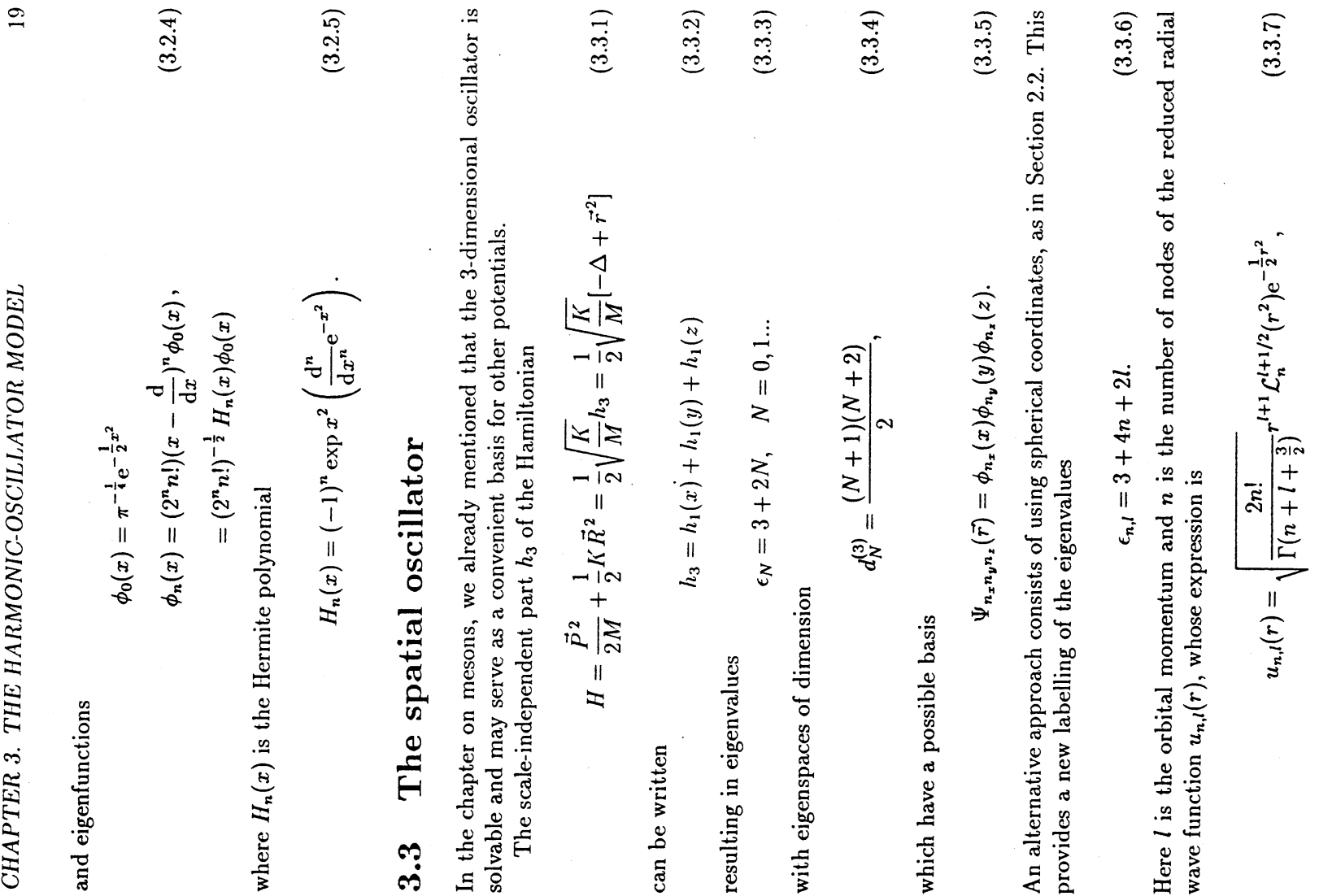



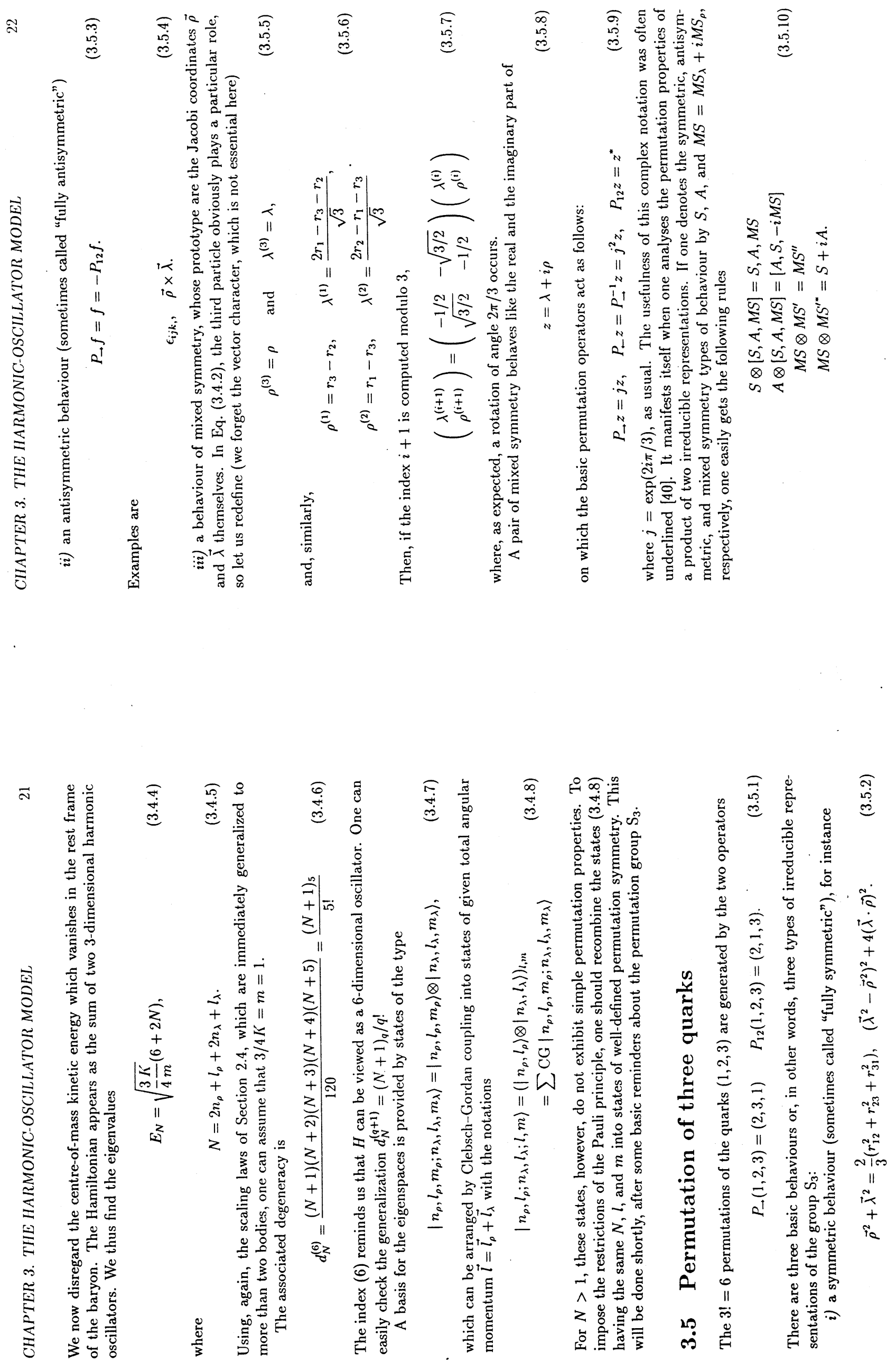

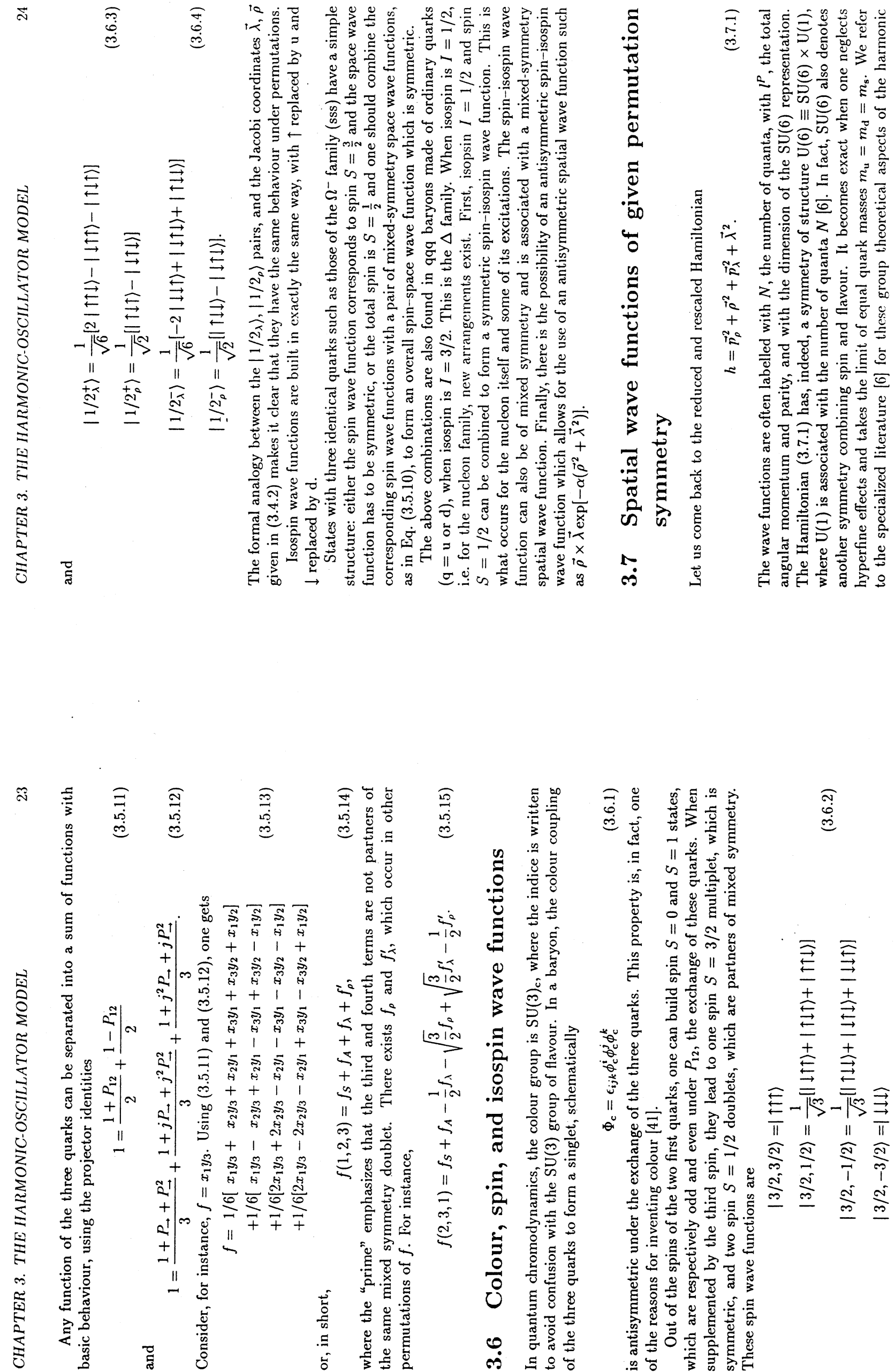

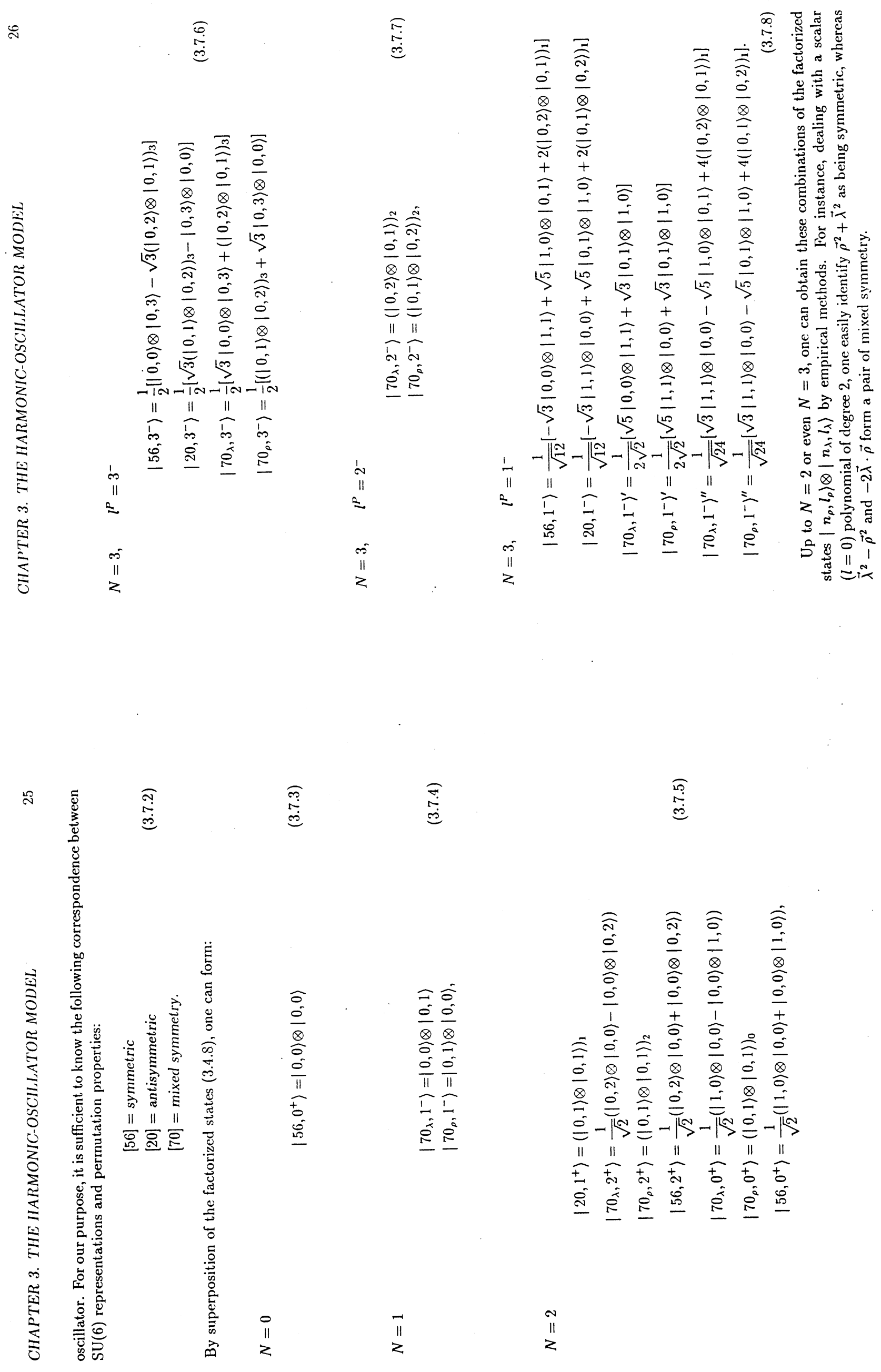


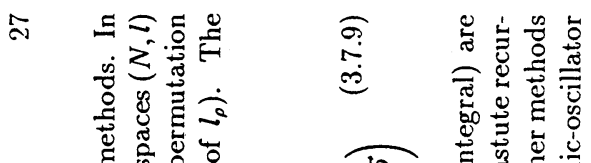

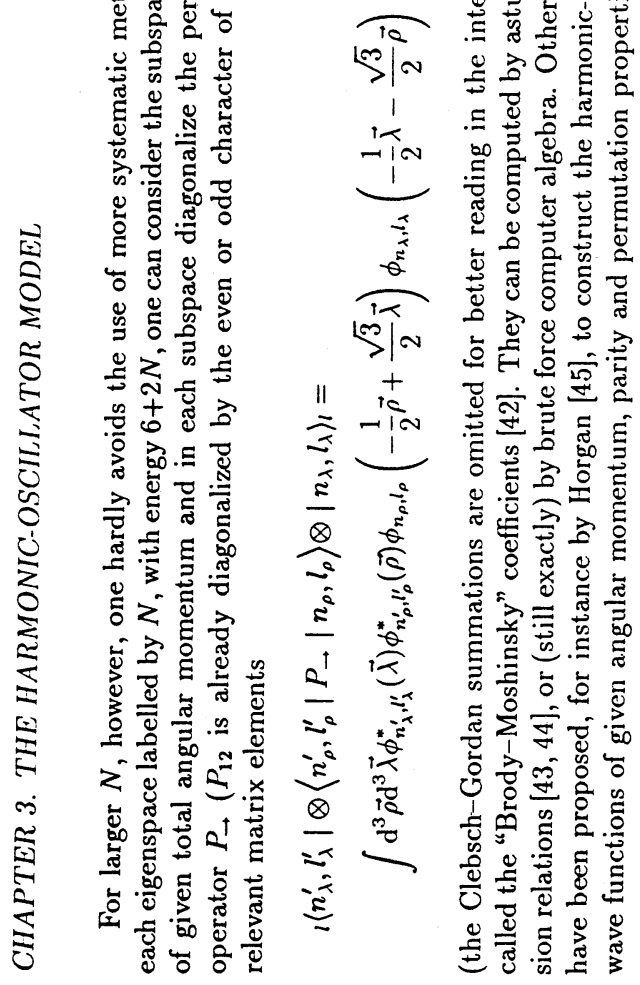

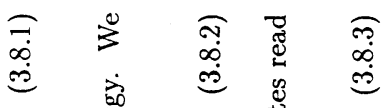

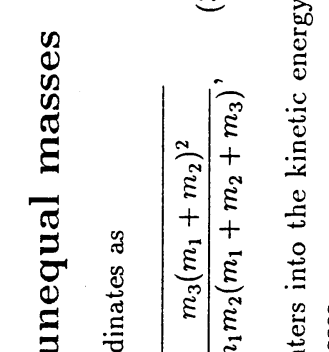

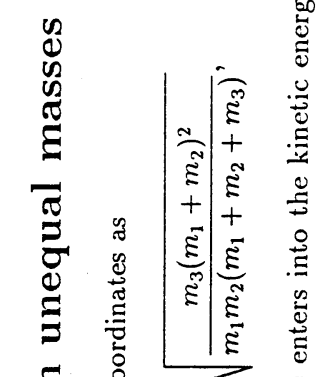

.

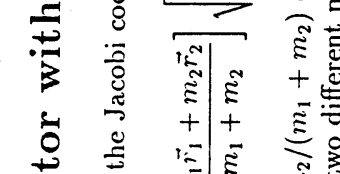

:

苛

$\infty$

$\begin{array}{ll}\infty & \Xi \\ \text { iे }\end{array}$ 《 हूँ

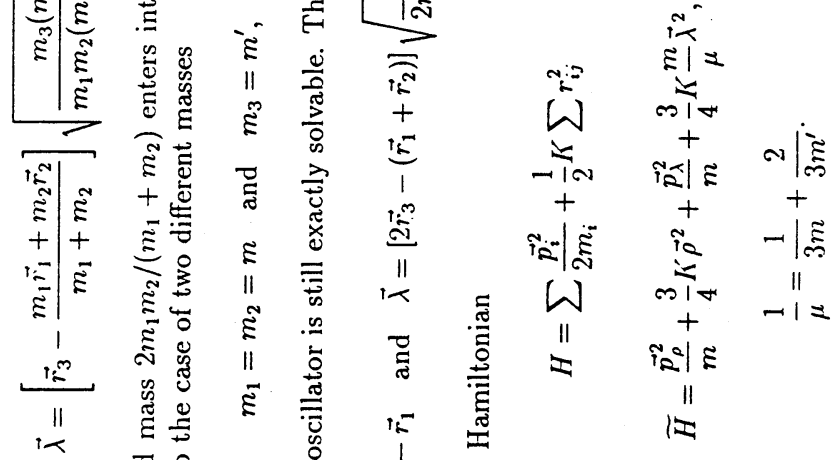

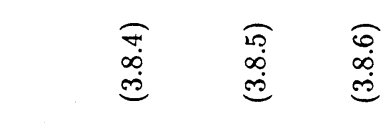

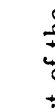

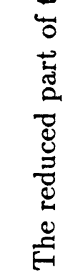



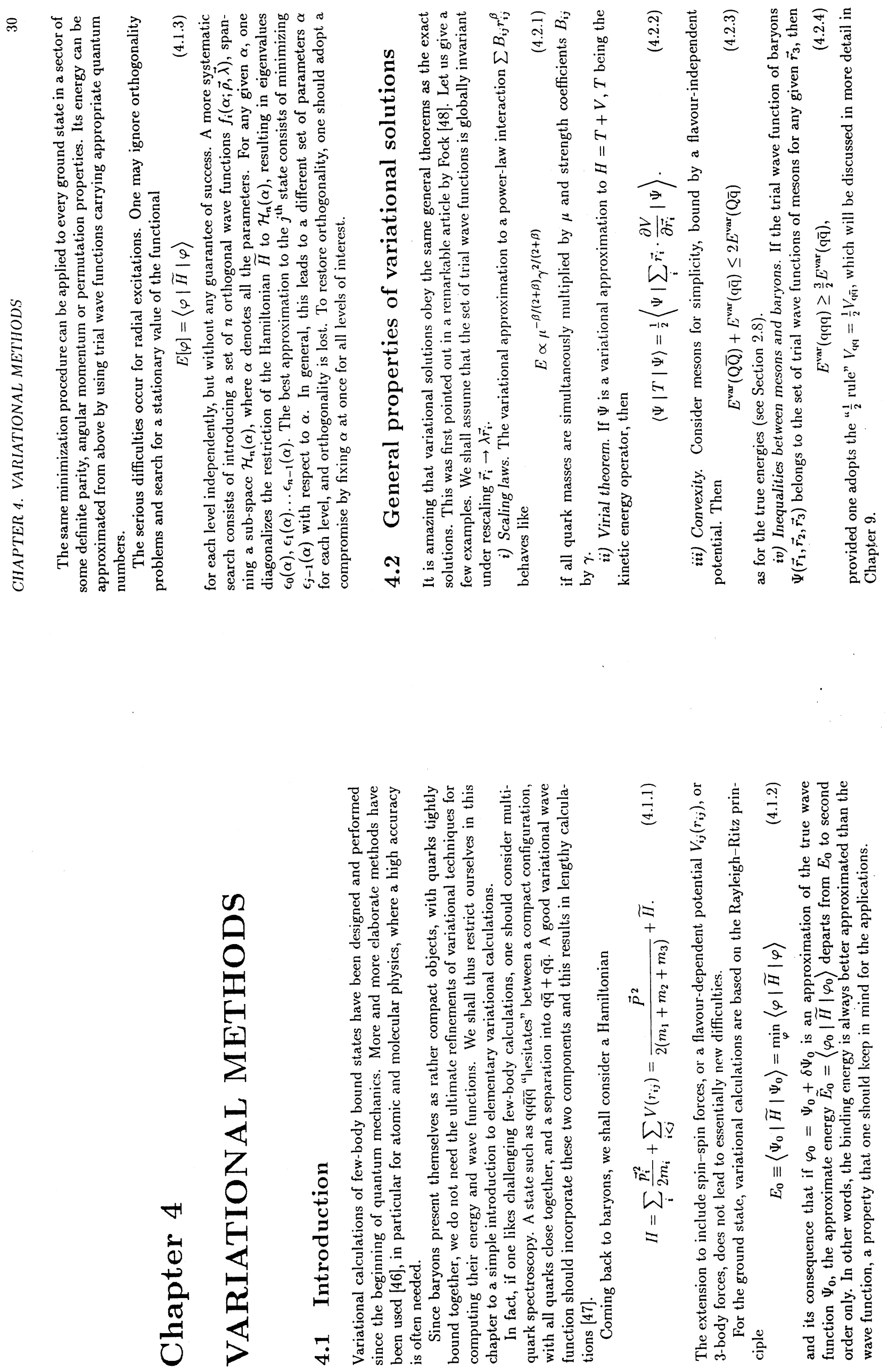


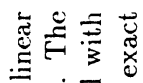

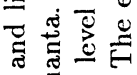

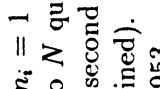

웅

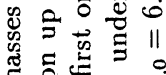

ह.

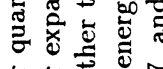

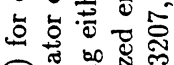

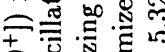

它.

过

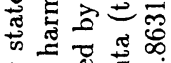

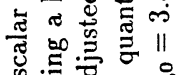

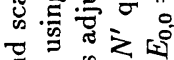

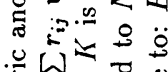

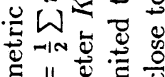

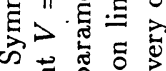

$\because$ 政

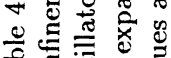

贾

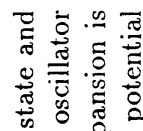

気

安䒠

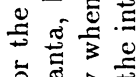

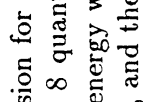

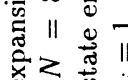

政

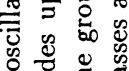

政

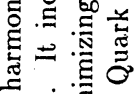

故安

능 11 字

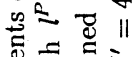

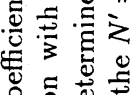

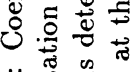

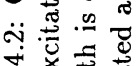

क区 要

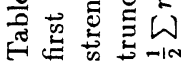

\begin{tabular}{|c|c|c|}
\hline $\begin{array}{ll}5 & 0 \\
1 & 11 \\
0 & 3\end{array}$ & 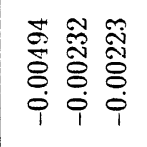 & 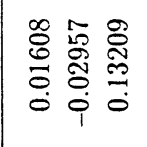 \\
\hline $\begin{array}{l}0 \\
0 \\
0 \\
0 \\
0\end{array}$ & 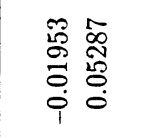 & 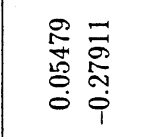 \\
\hline$\sigma^{\pi}$ & 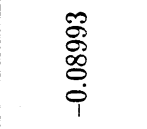 & $\begin{array}{l}\text { 序 } \\
\text { o }\end{array}$ \\
\hline 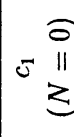 & 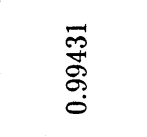 & $\begin{array}{l}\stackrel{8}{0} \\
\stackrel{0}{0} \\
0\end{array}$ \\
\hline 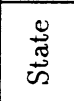 & $\begin{array}{l}i \\
\text { II }\end{array}$ & $\underset{\approx}{\|}$ \\
\hline
\end{tabular}



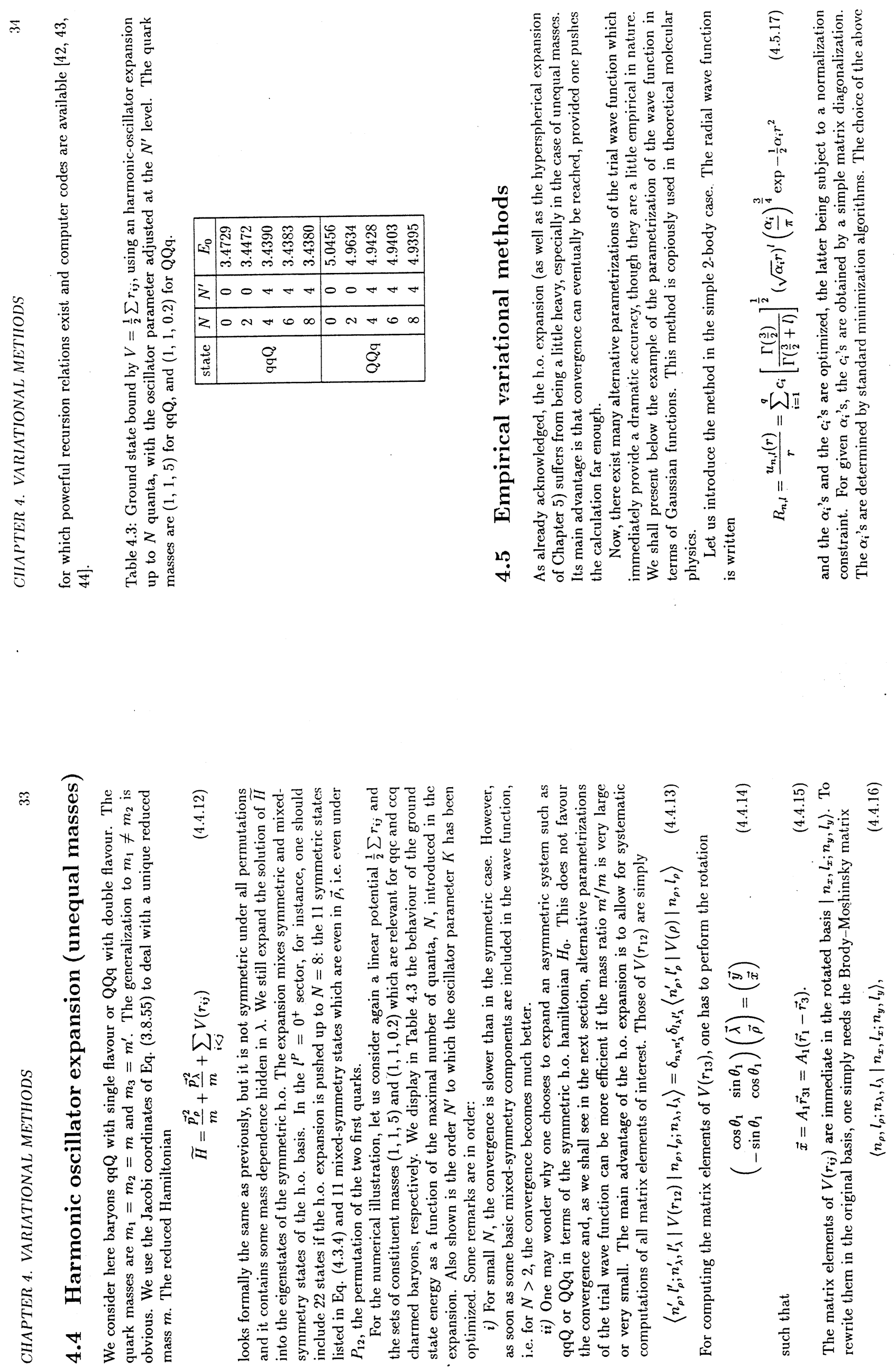

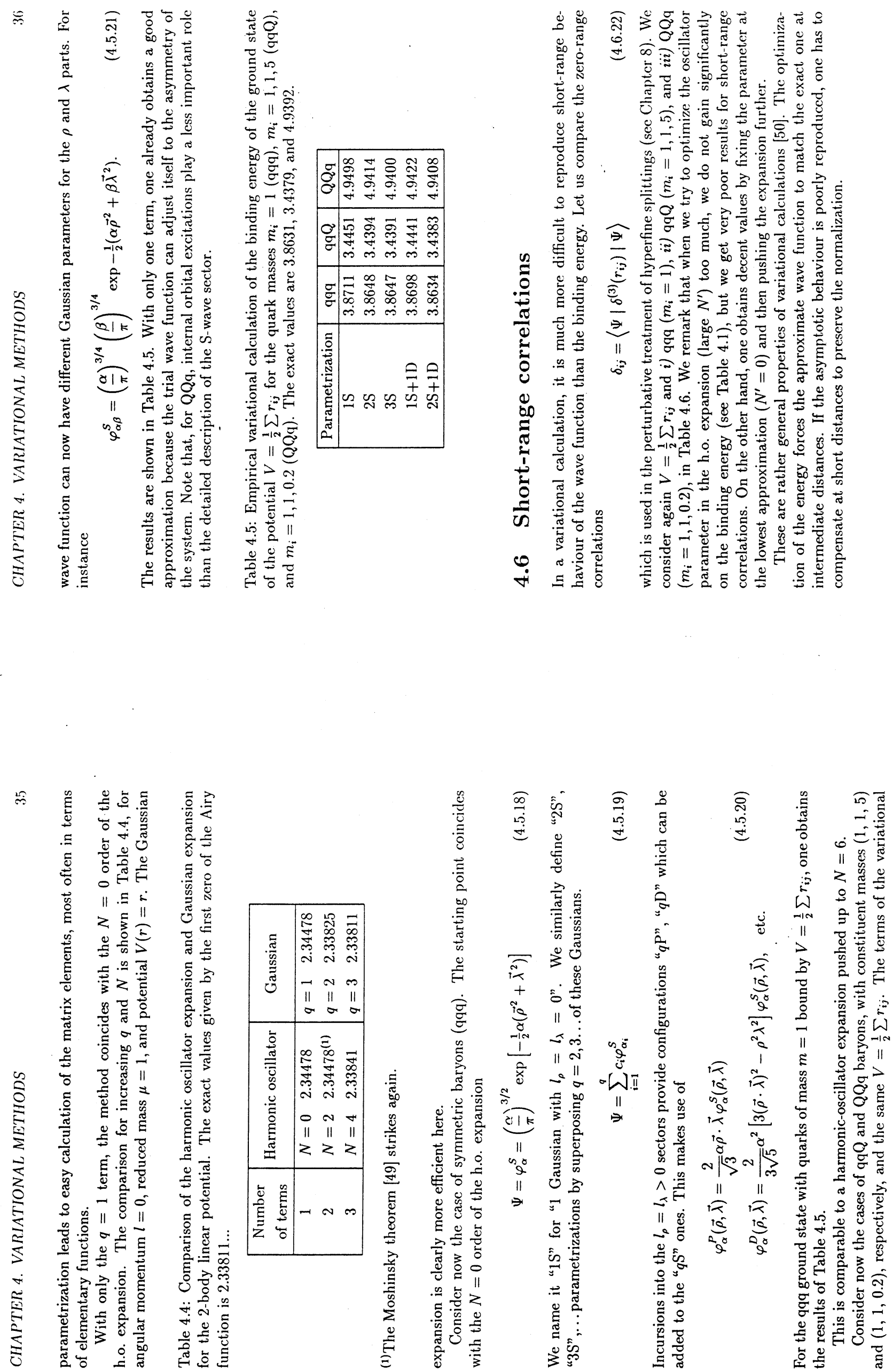


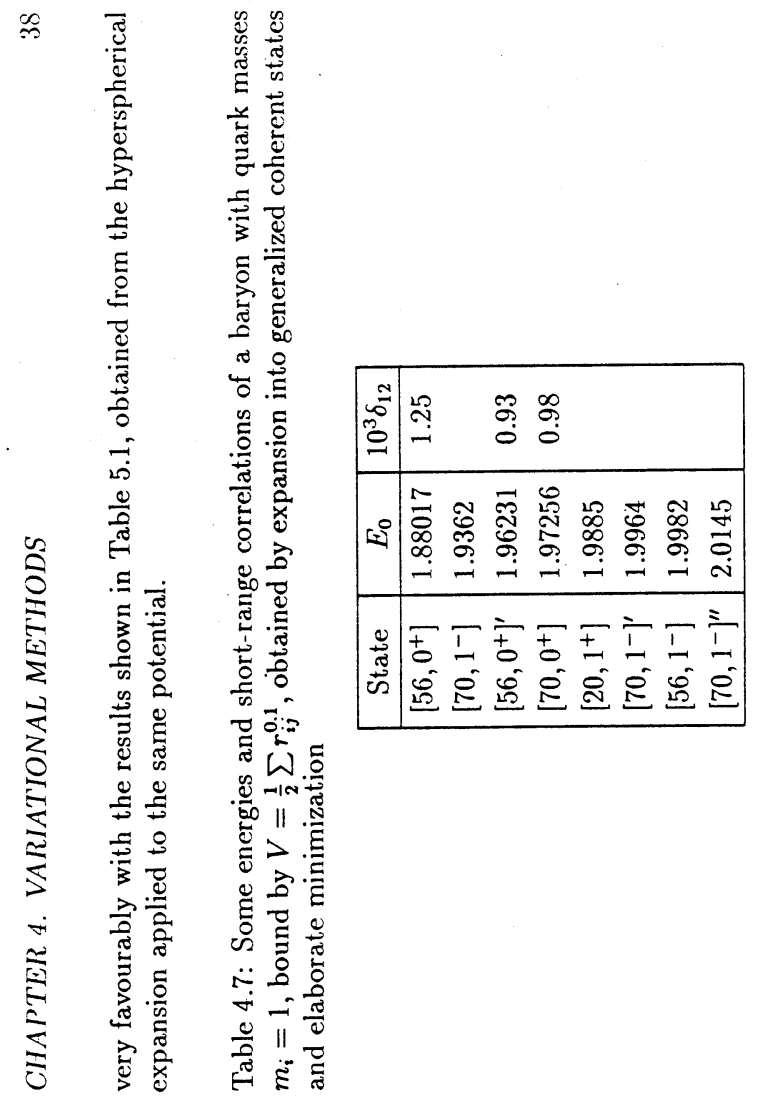

5

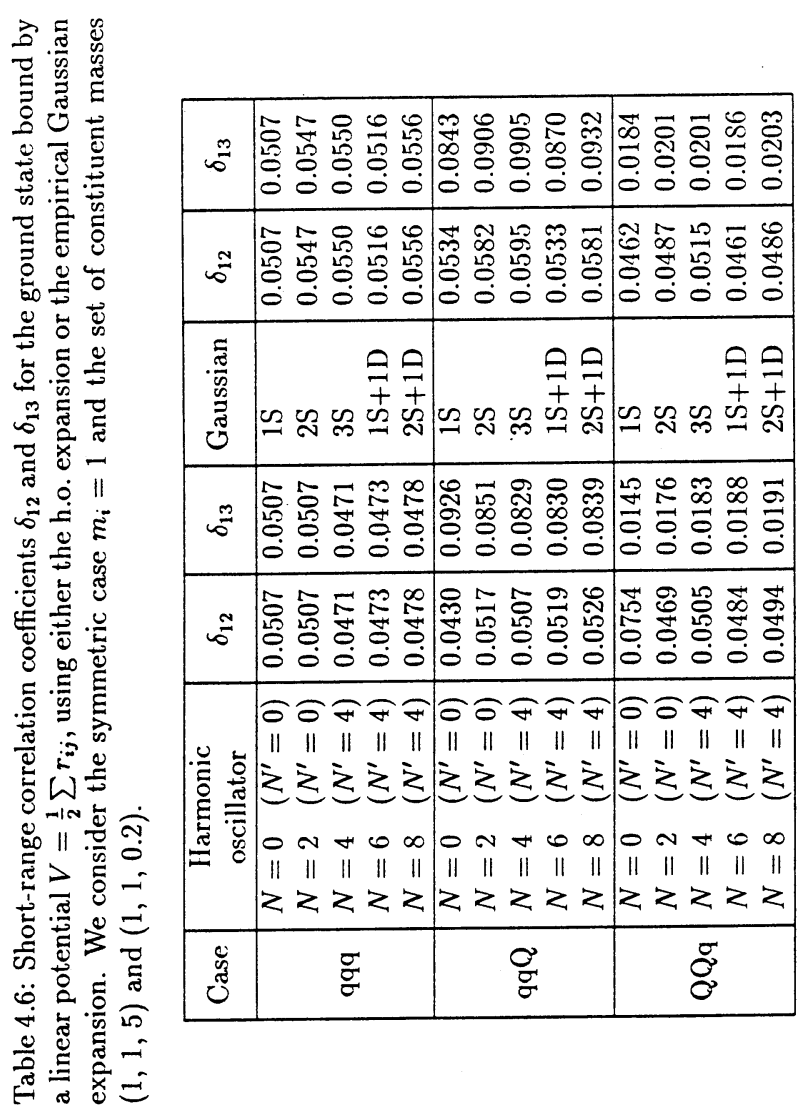

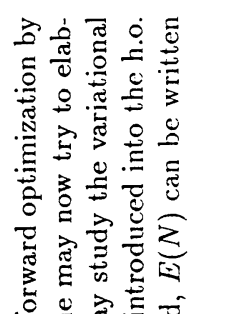

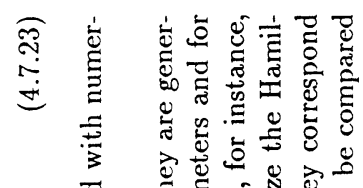

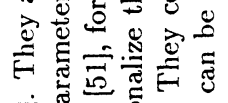

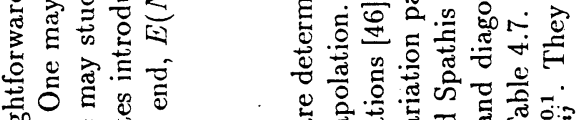

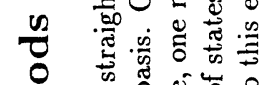

की

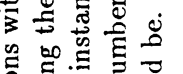

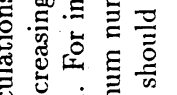

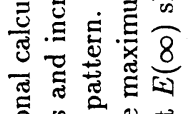

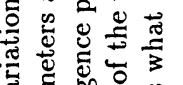

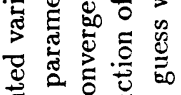

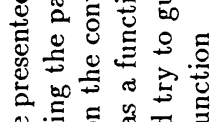

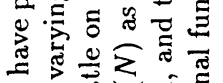

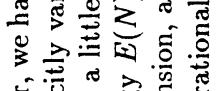

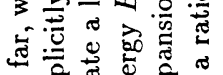

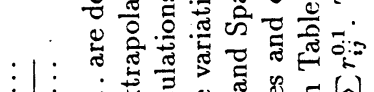

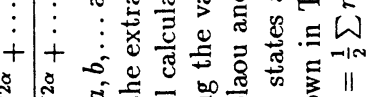

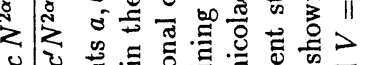

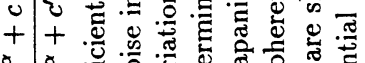

$\sum_{0} \sum_{0}^{0} \stackrel{0}{0}$

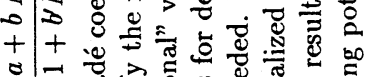

II

之 Ð

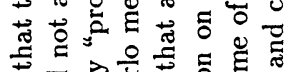

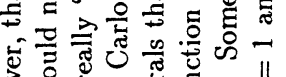

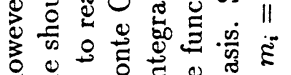

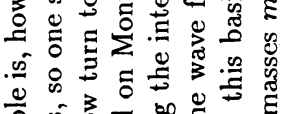

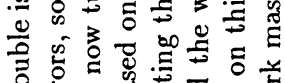

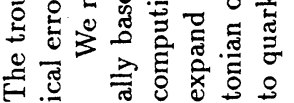



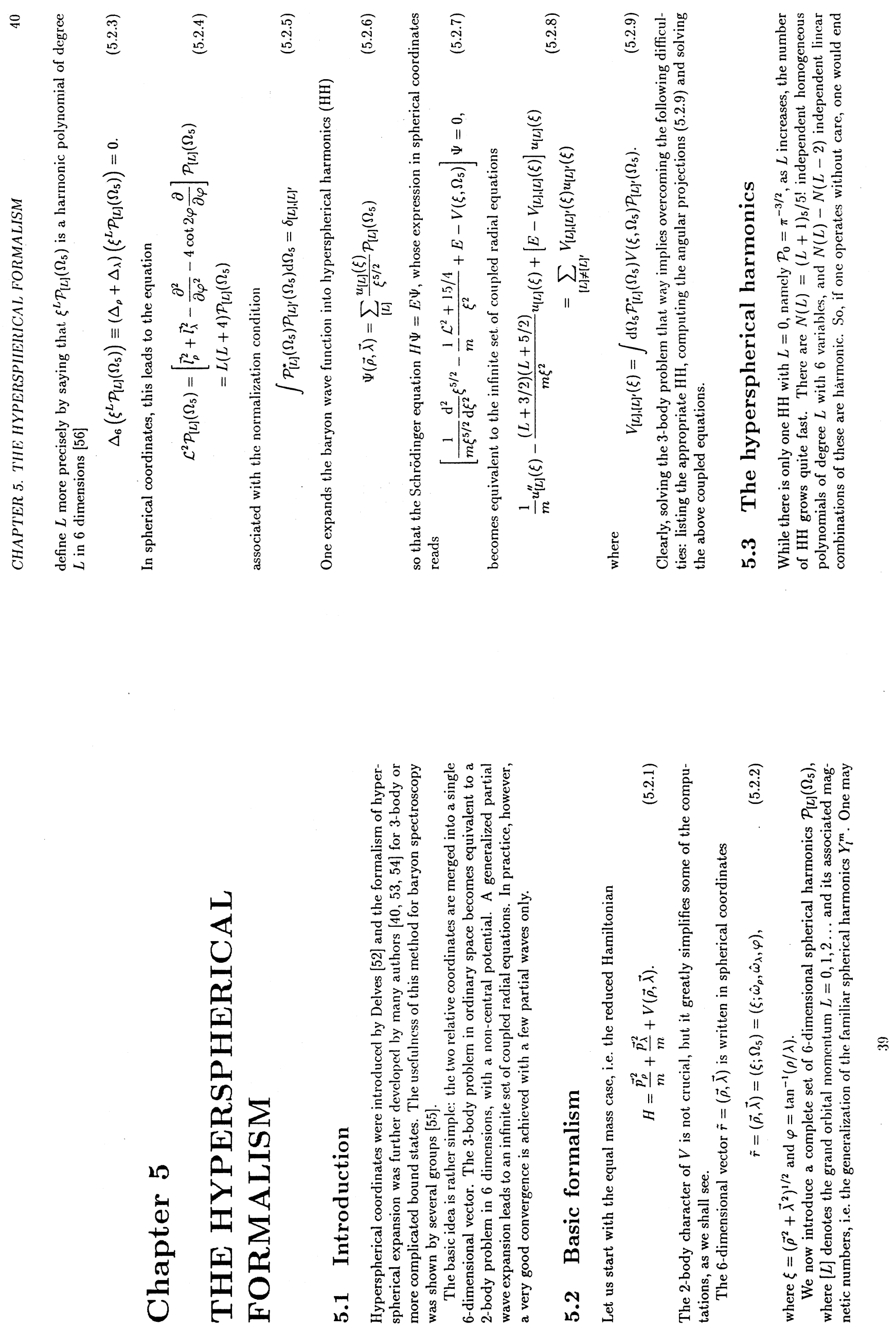

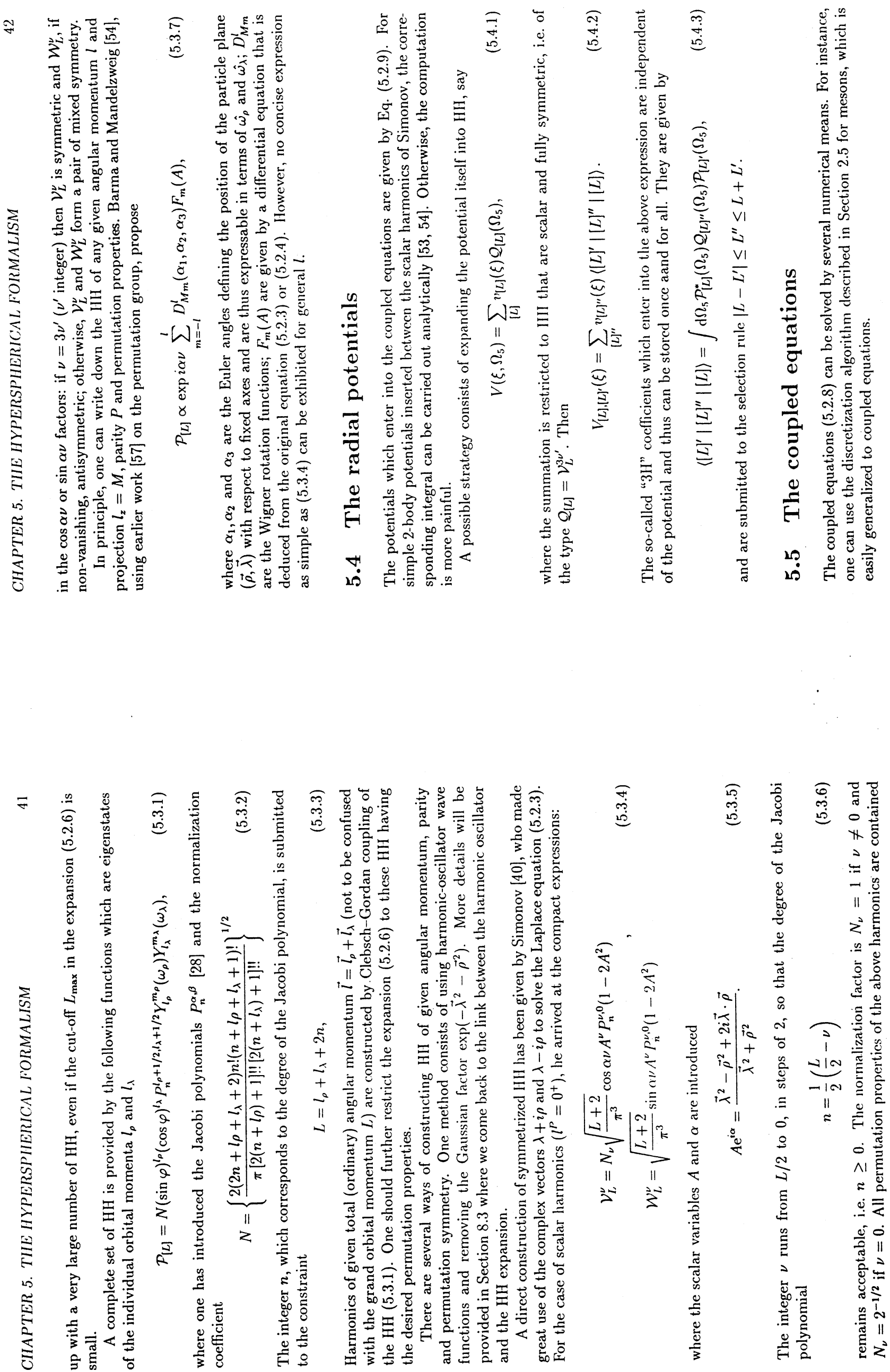

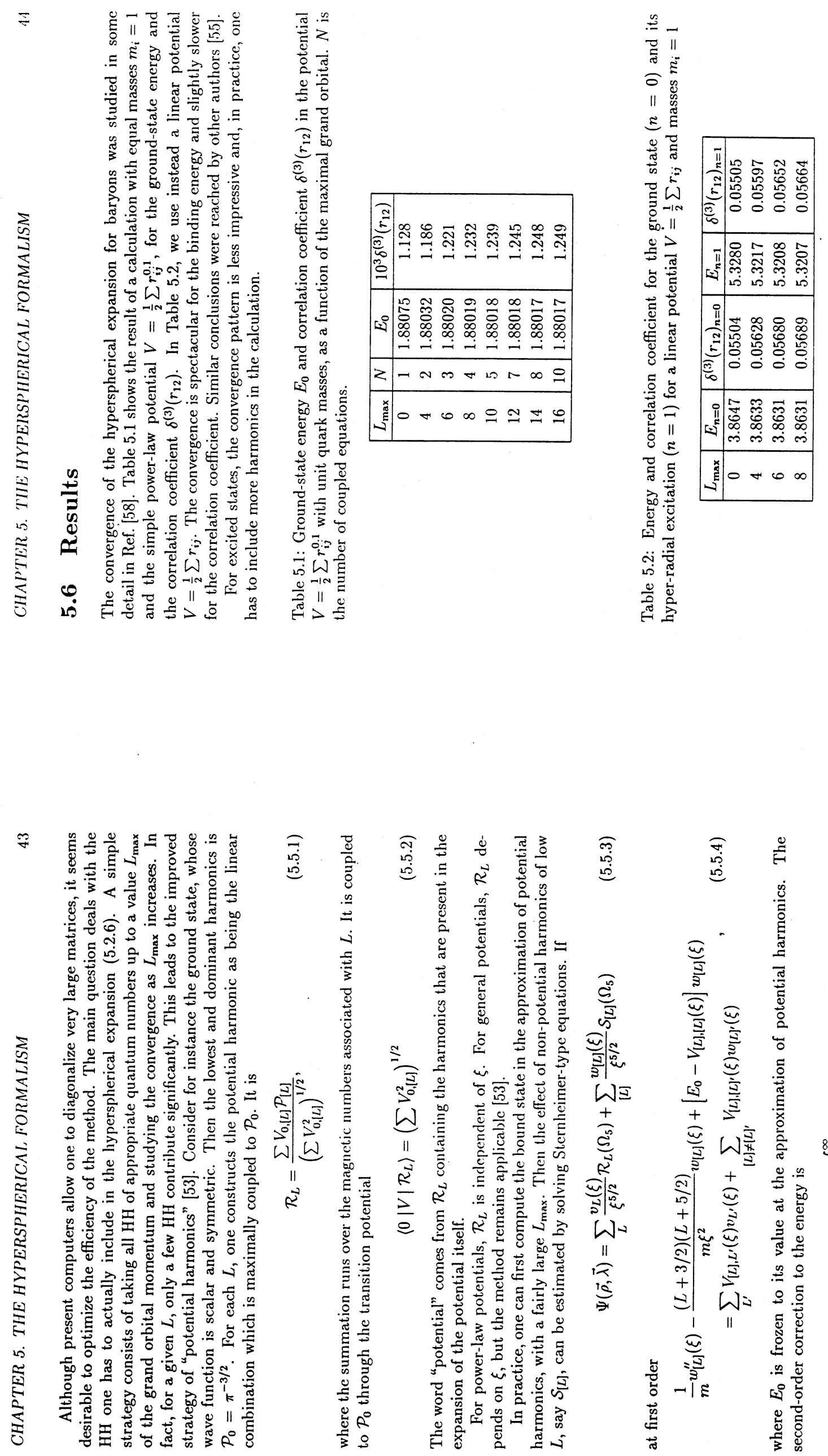

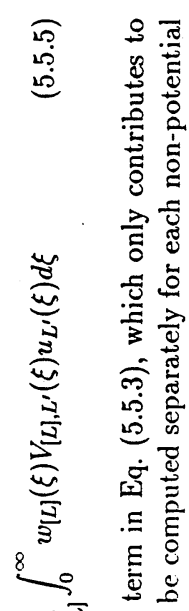

W㾞

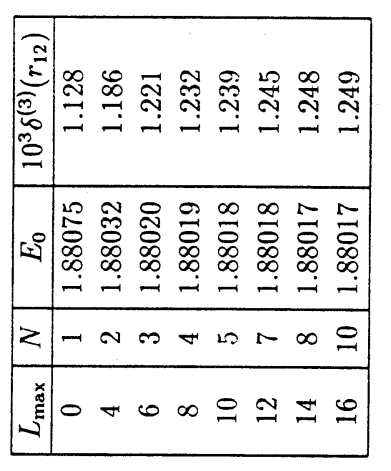

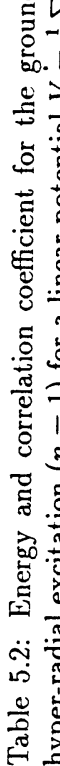



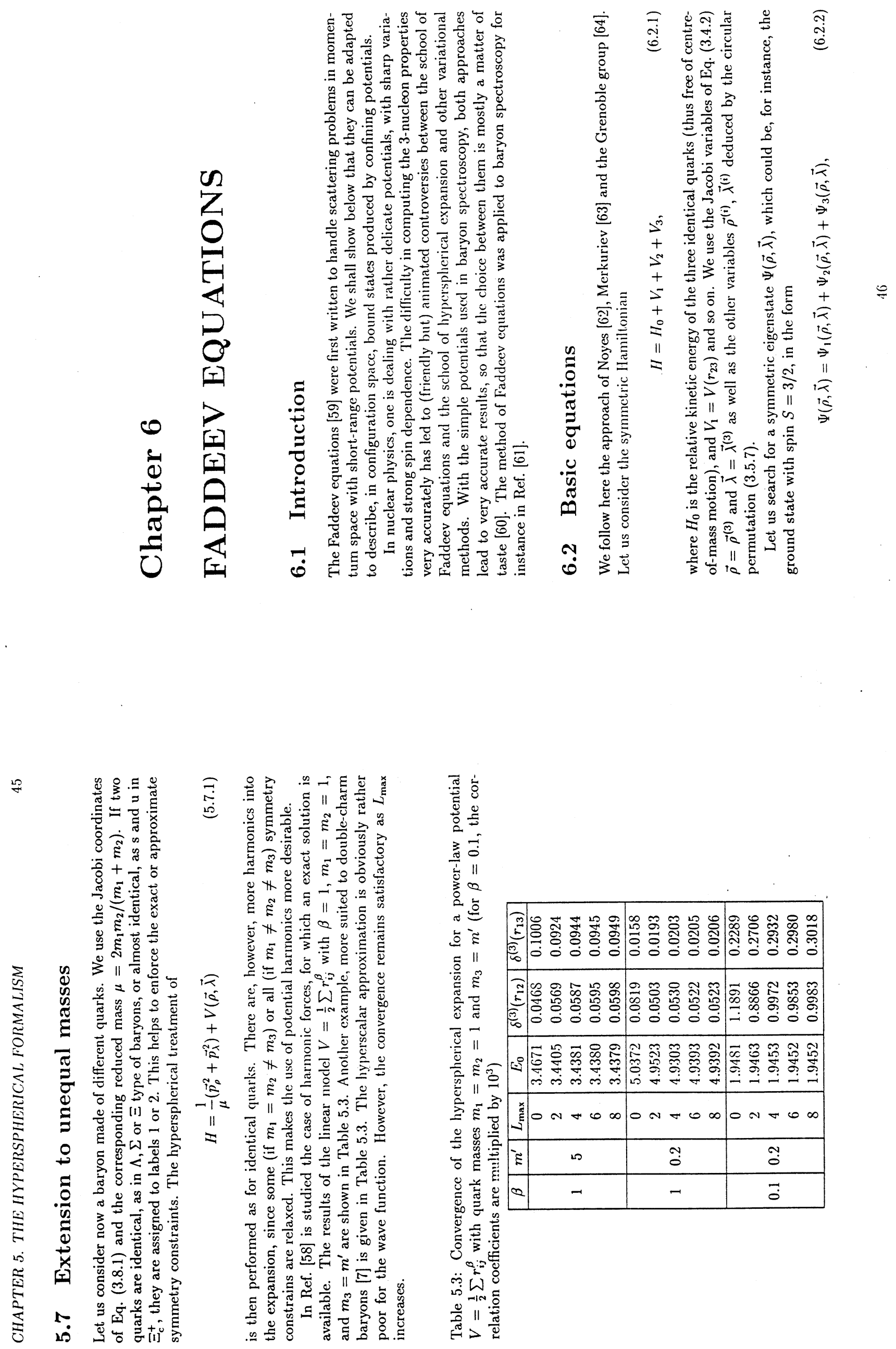

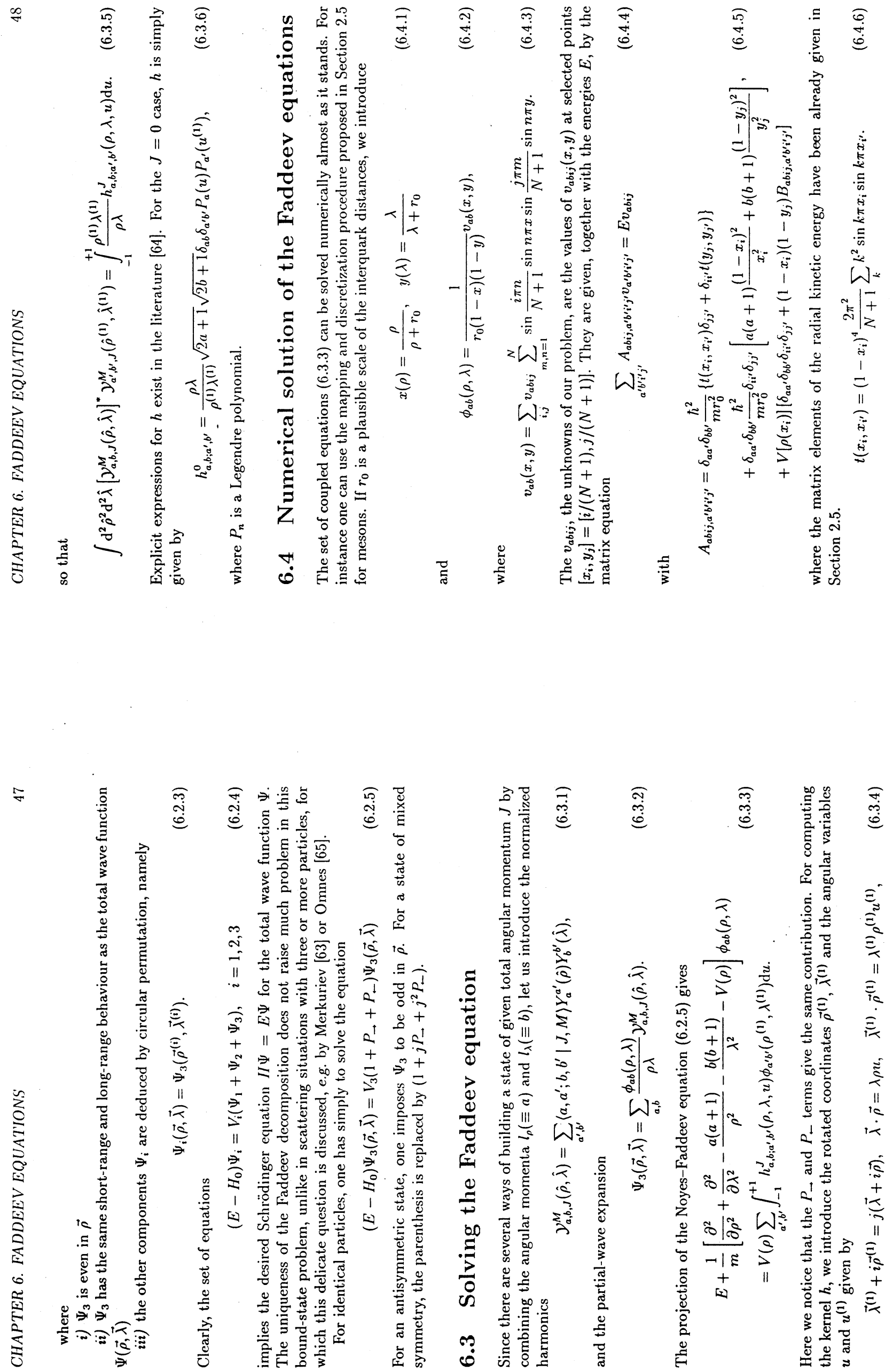

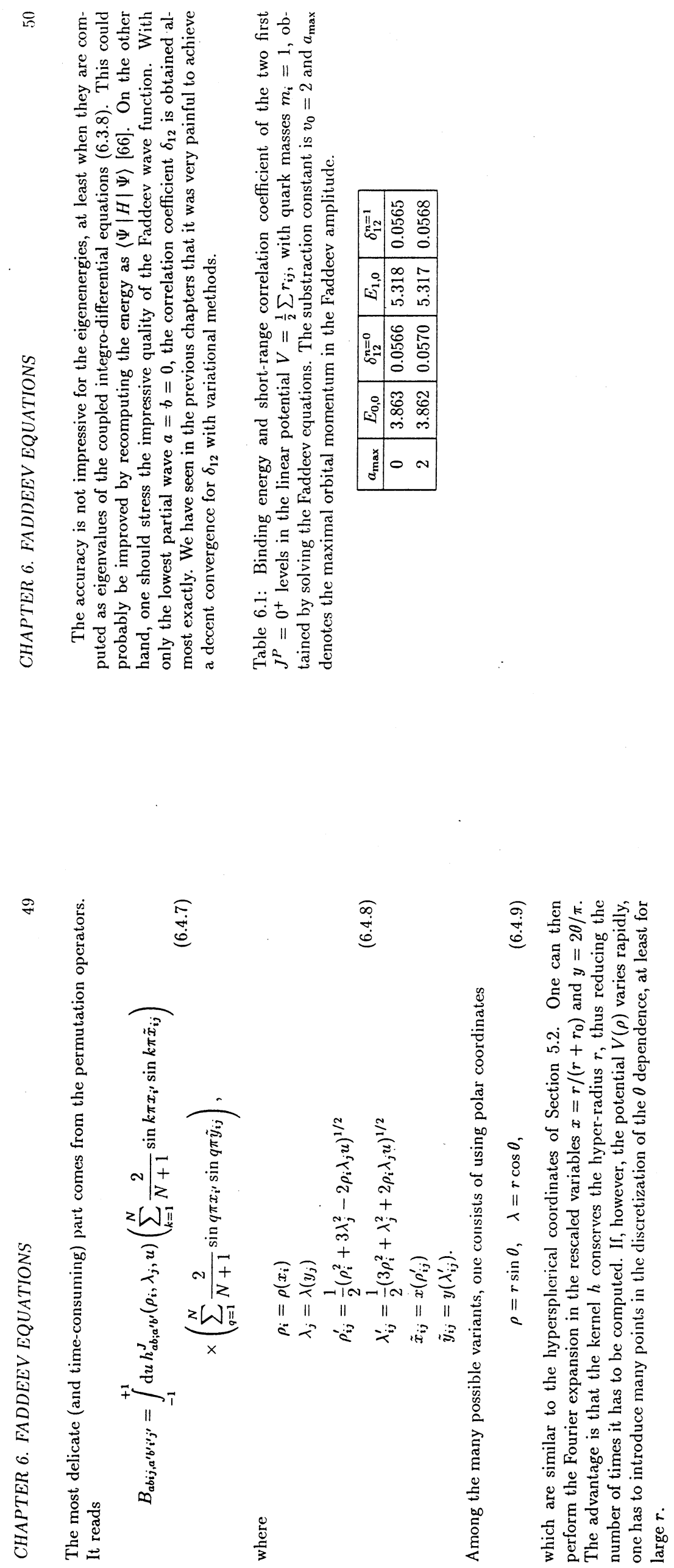

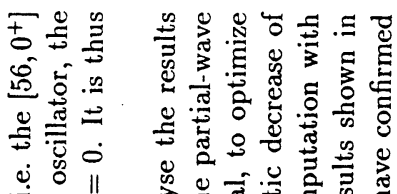

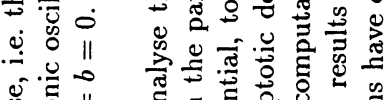

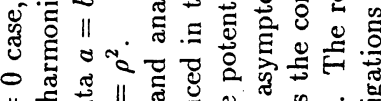

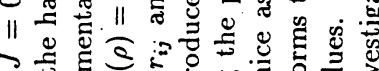

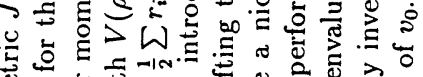

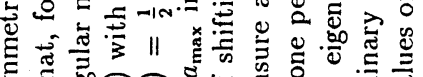
芴

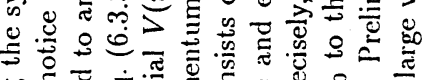

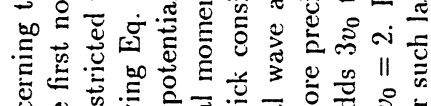

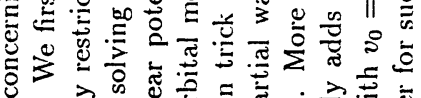

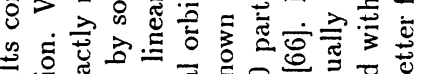

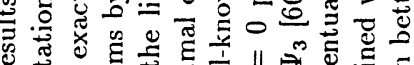

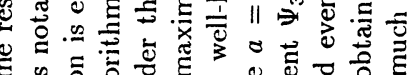

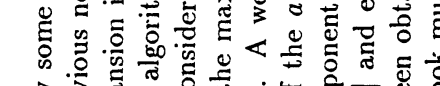

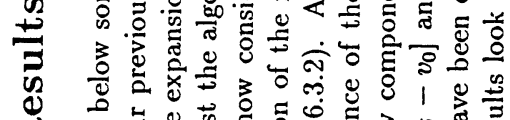
出

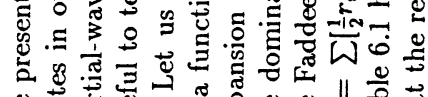

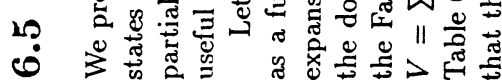



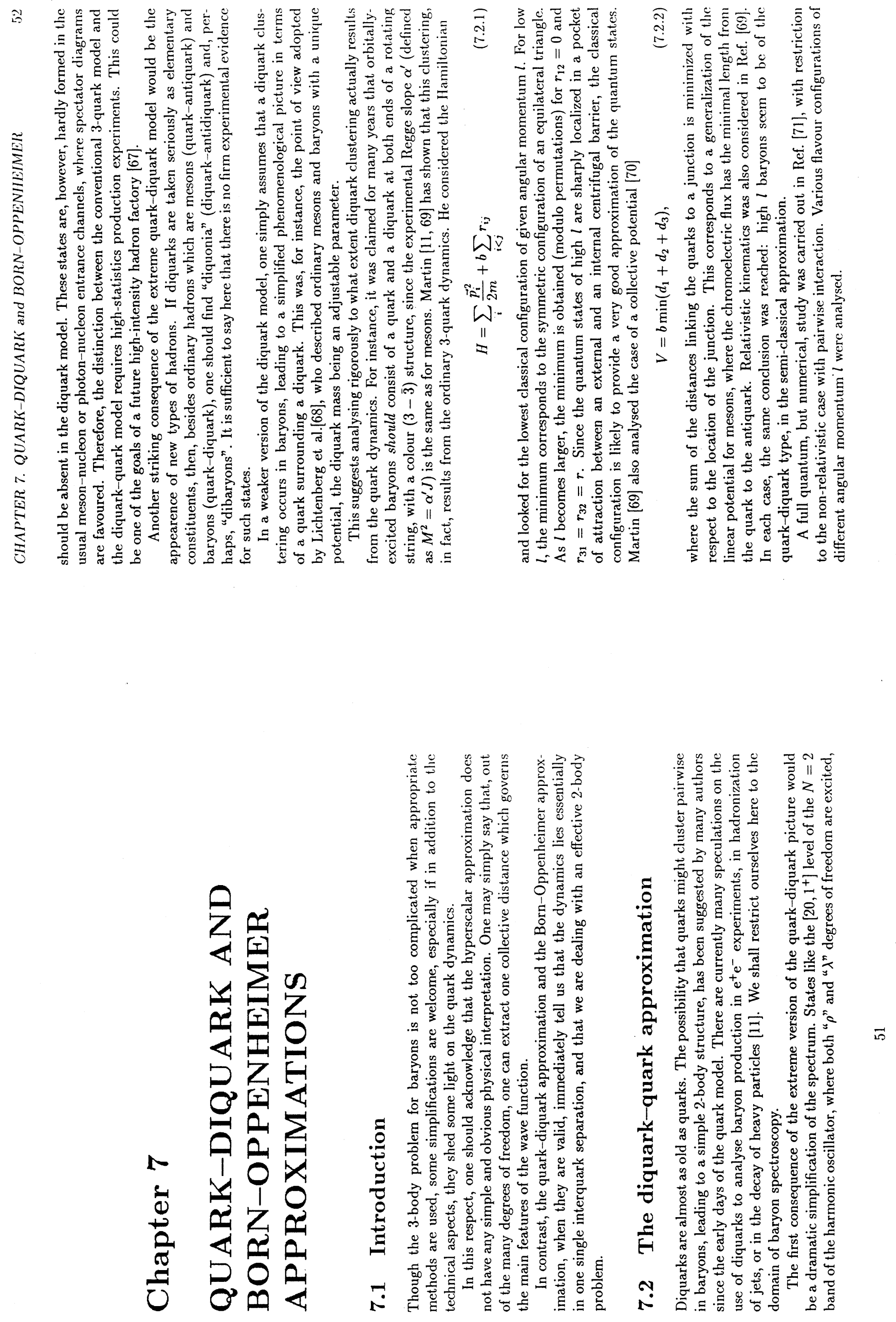


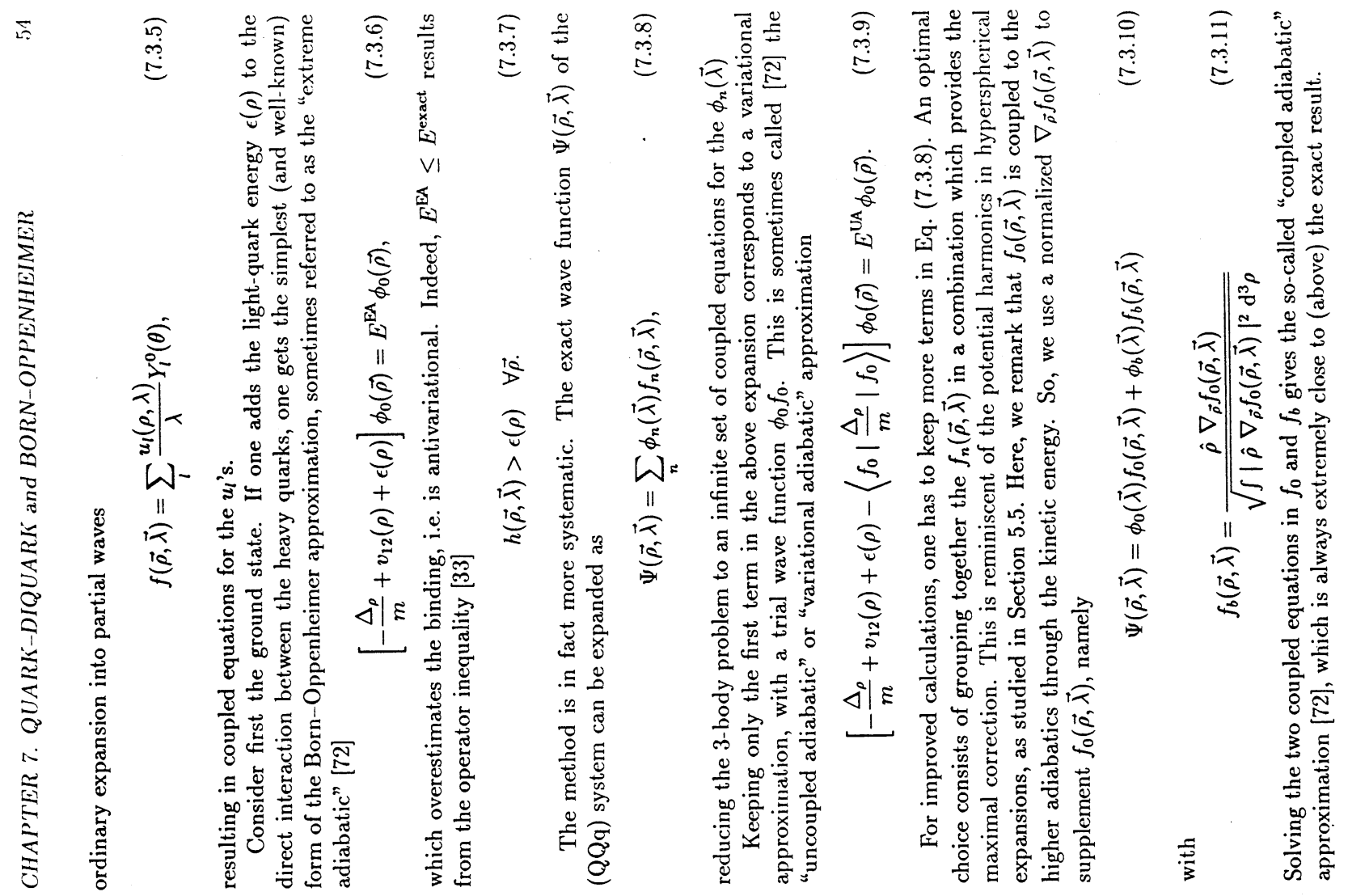

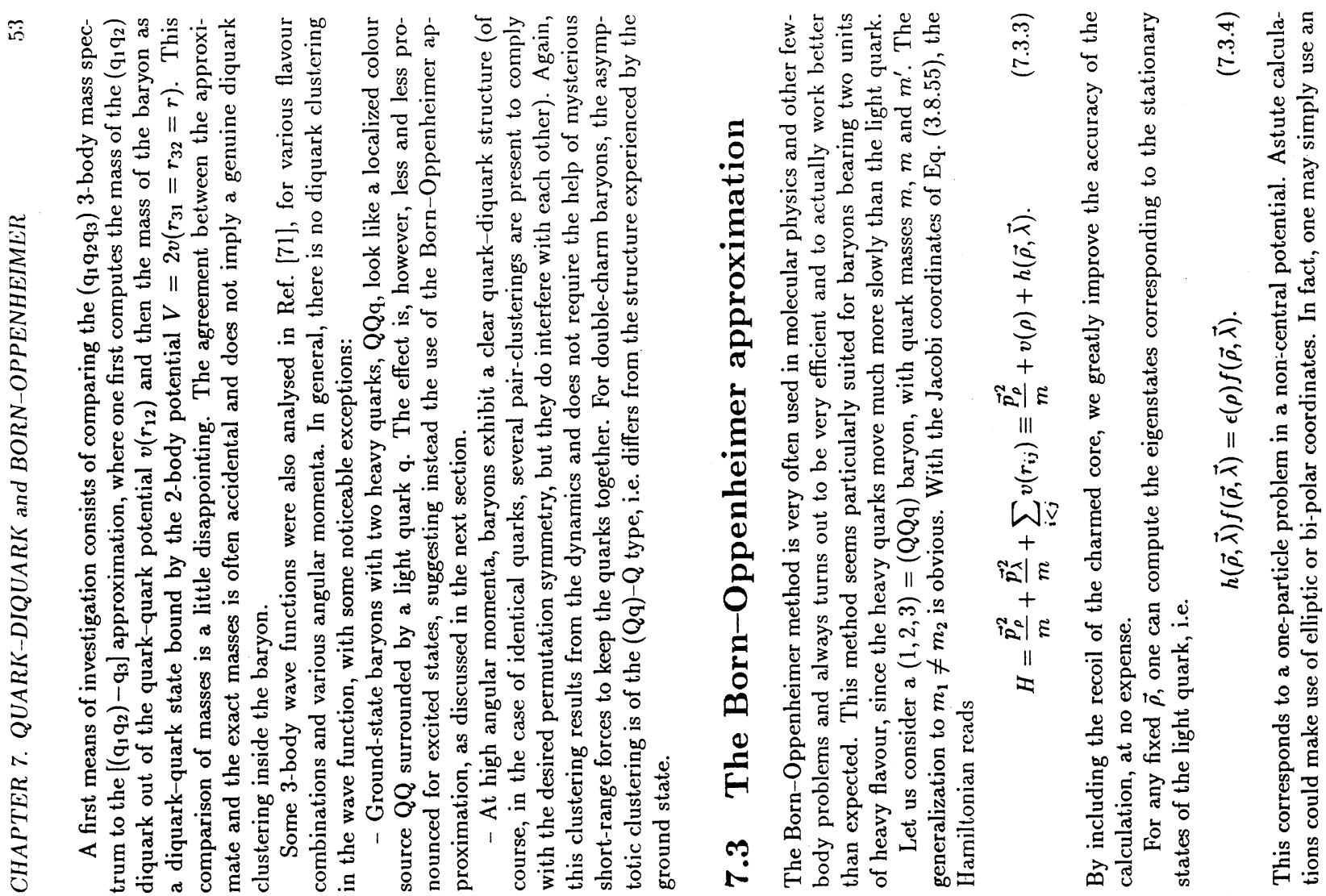



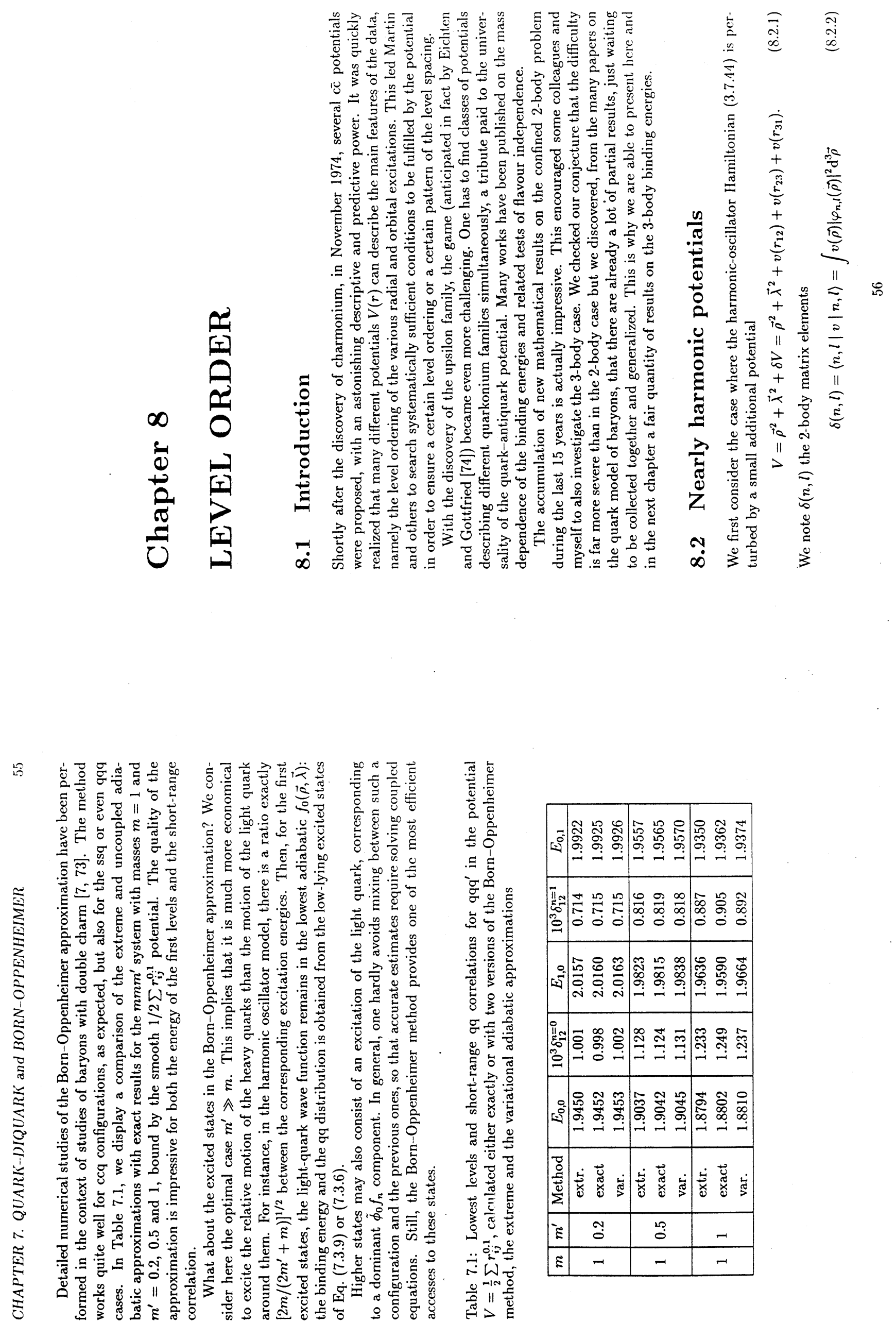

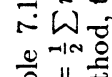




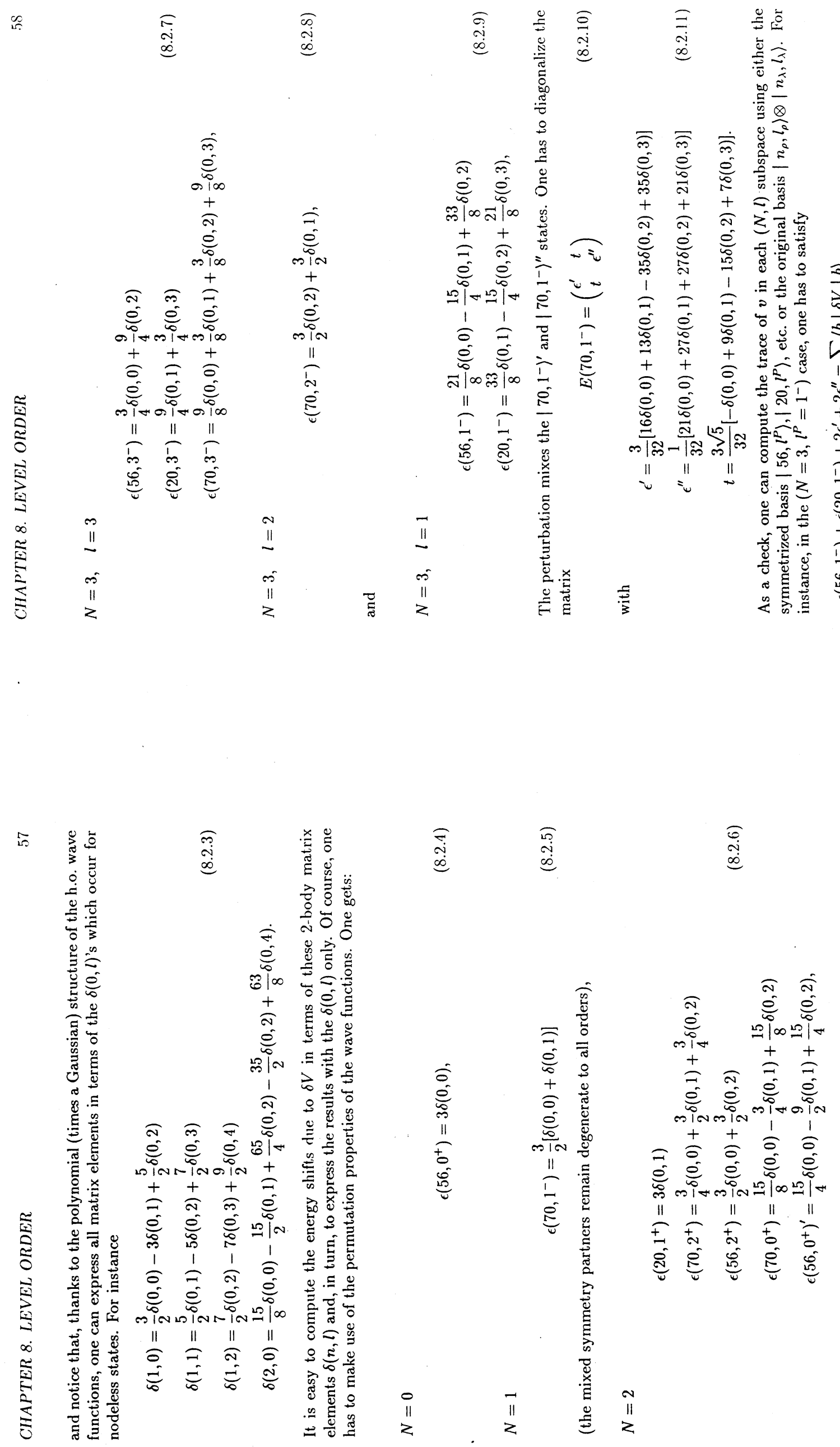




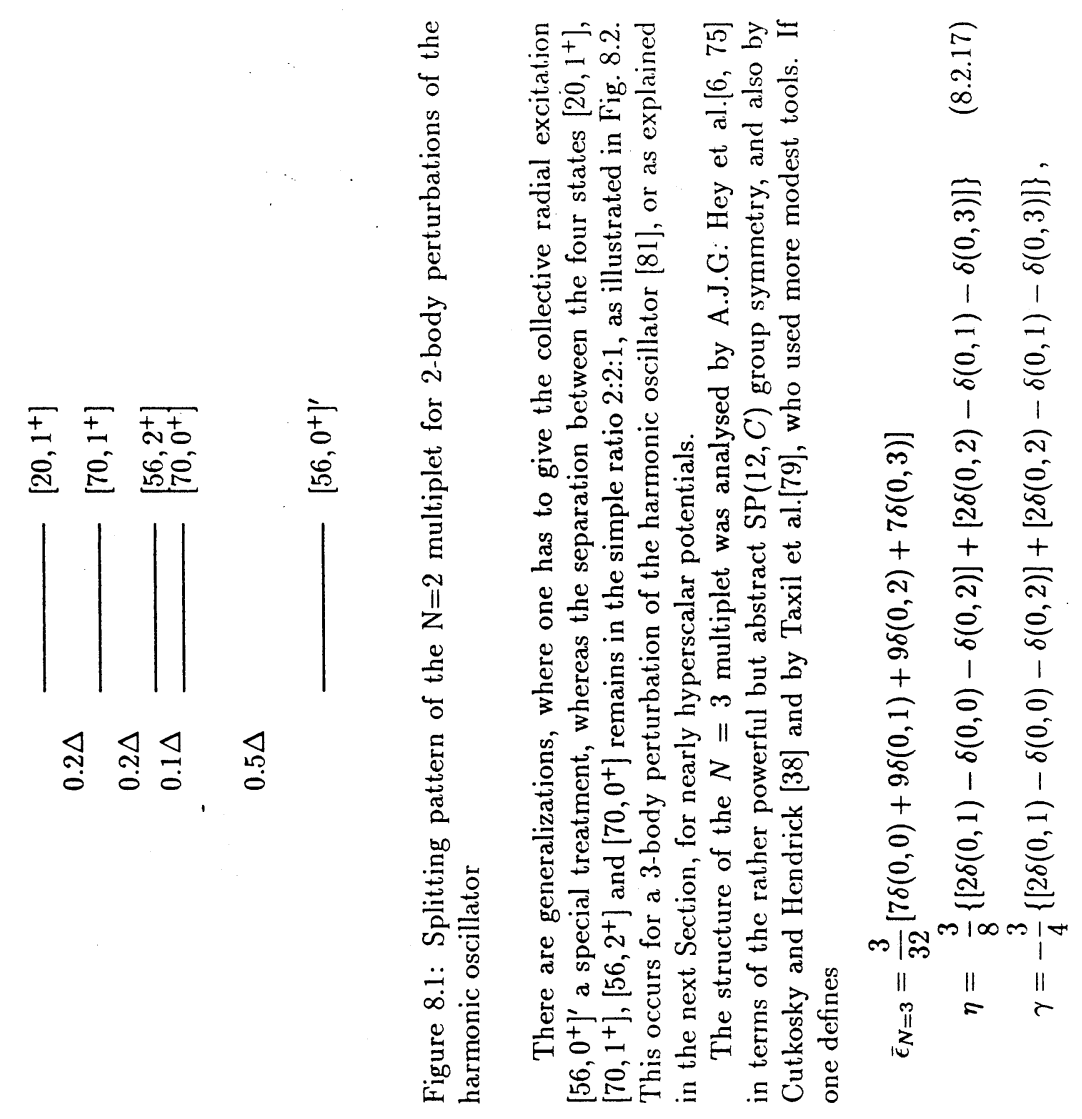

8

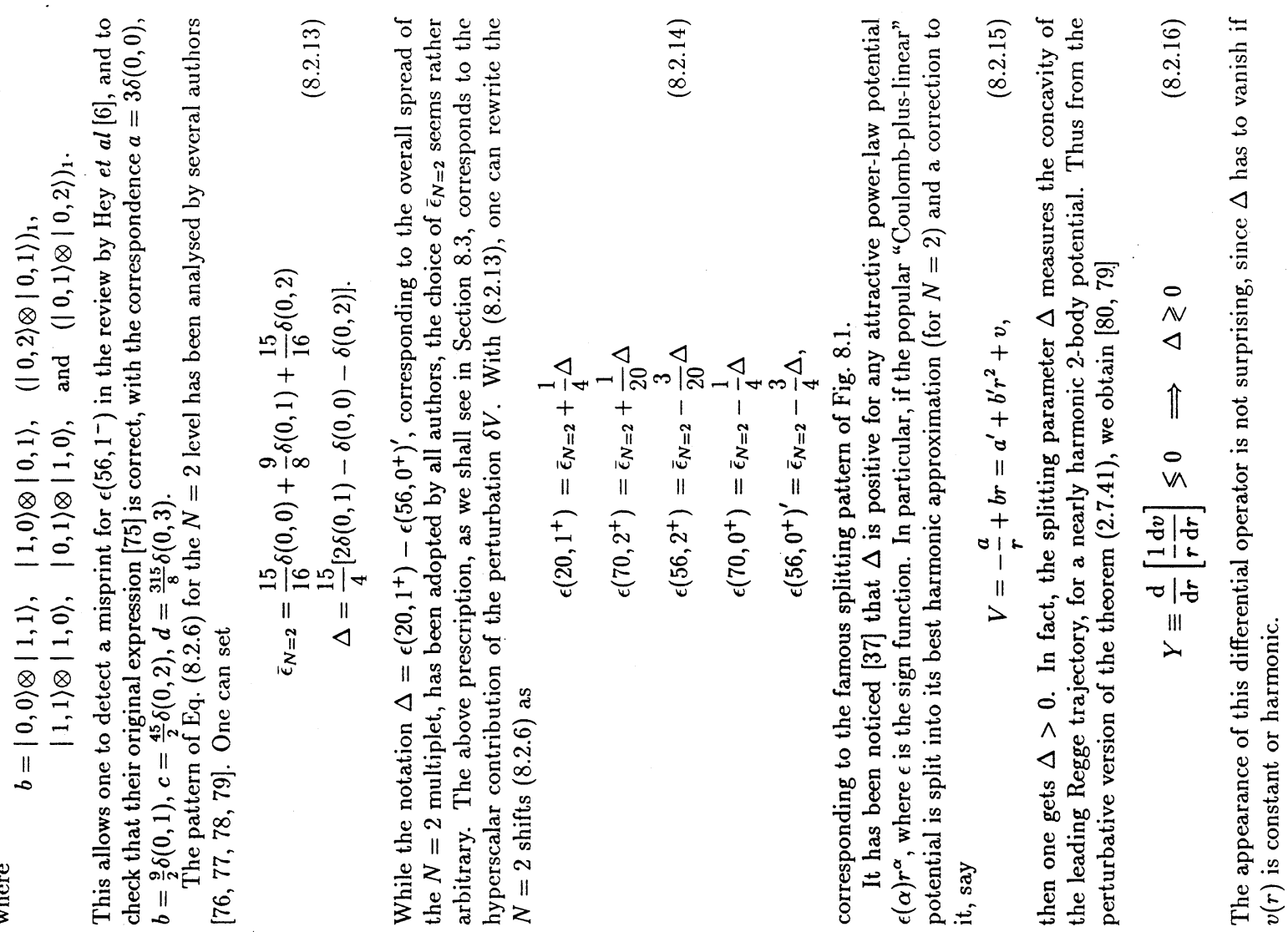



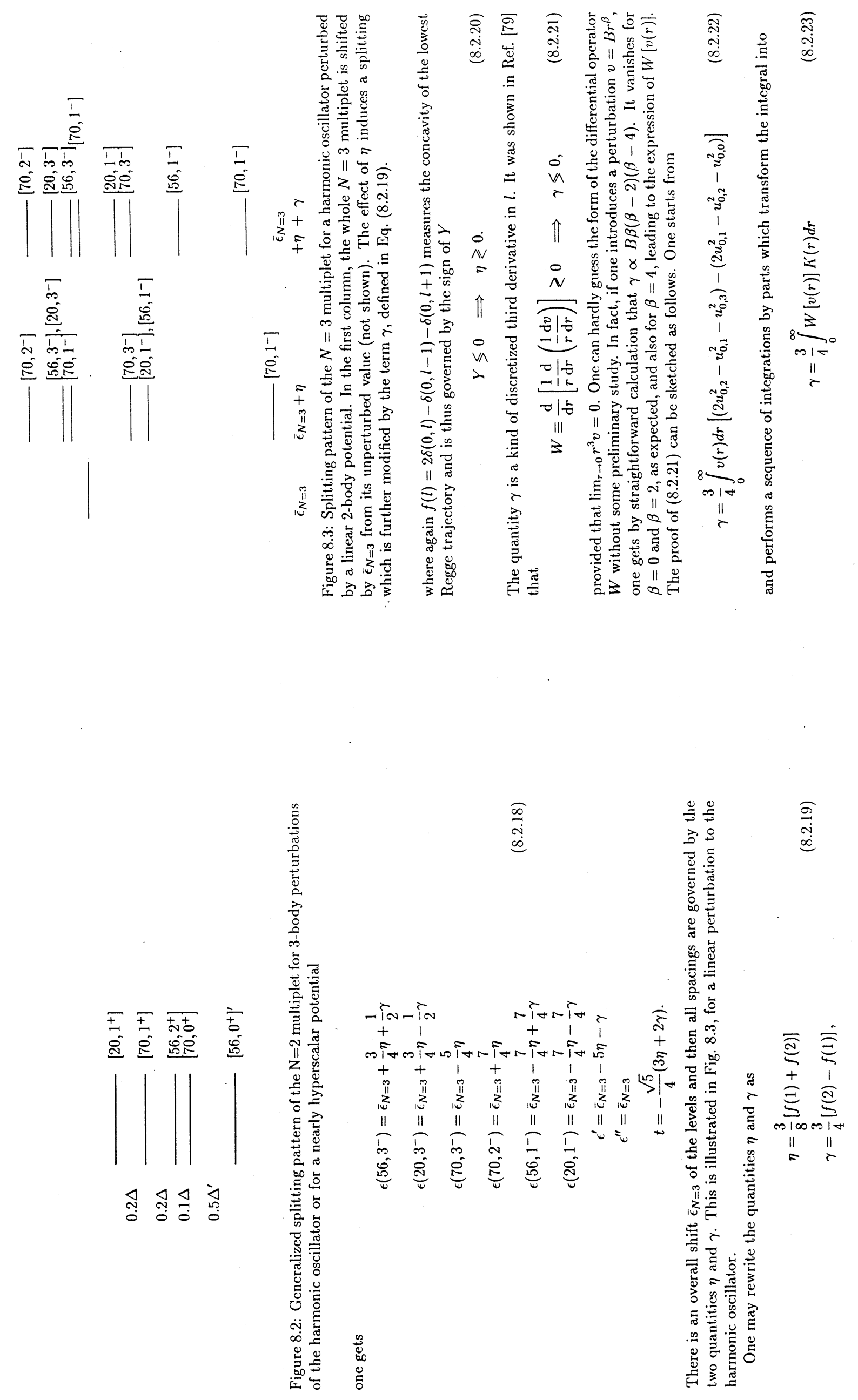

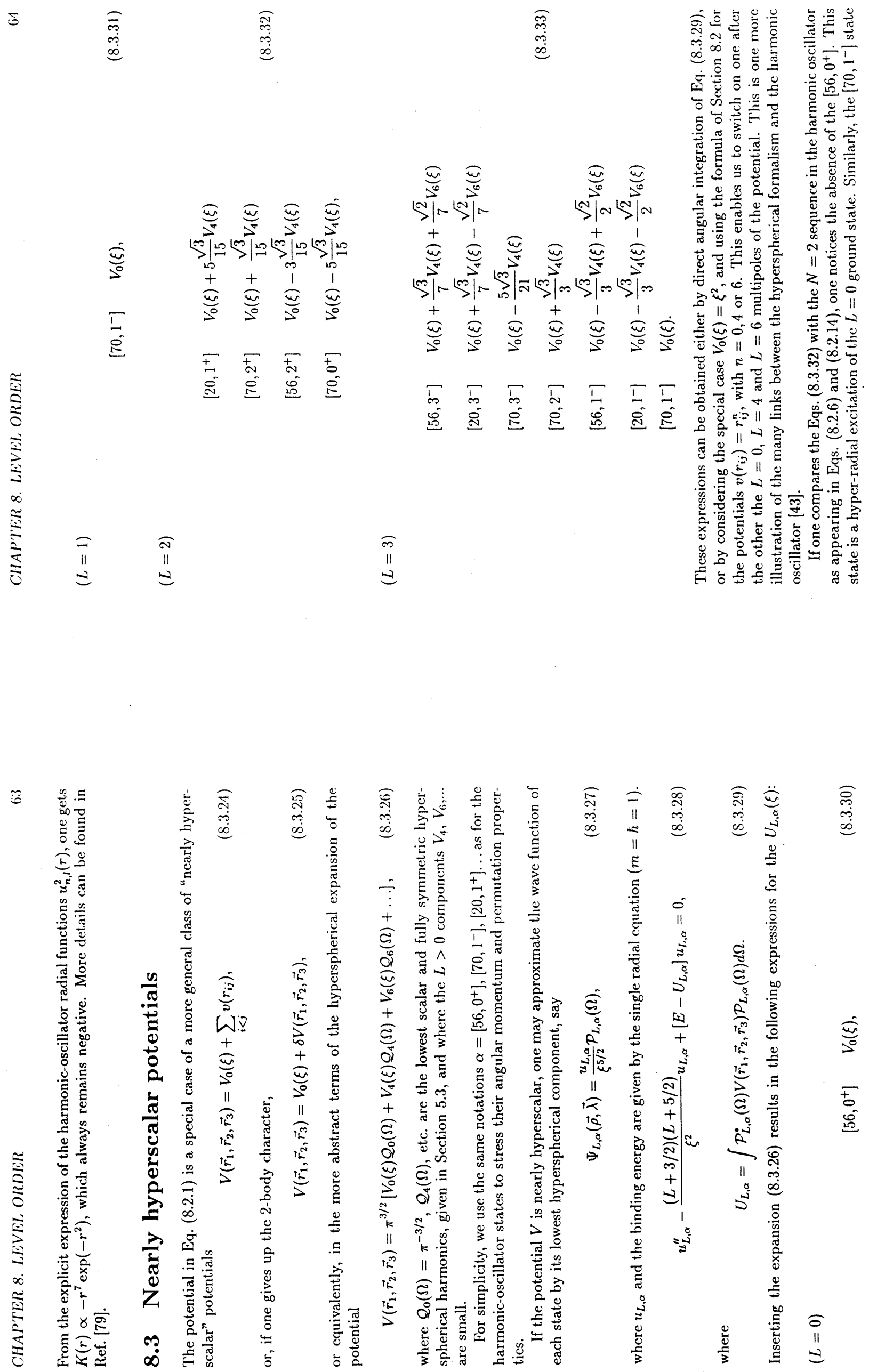
告

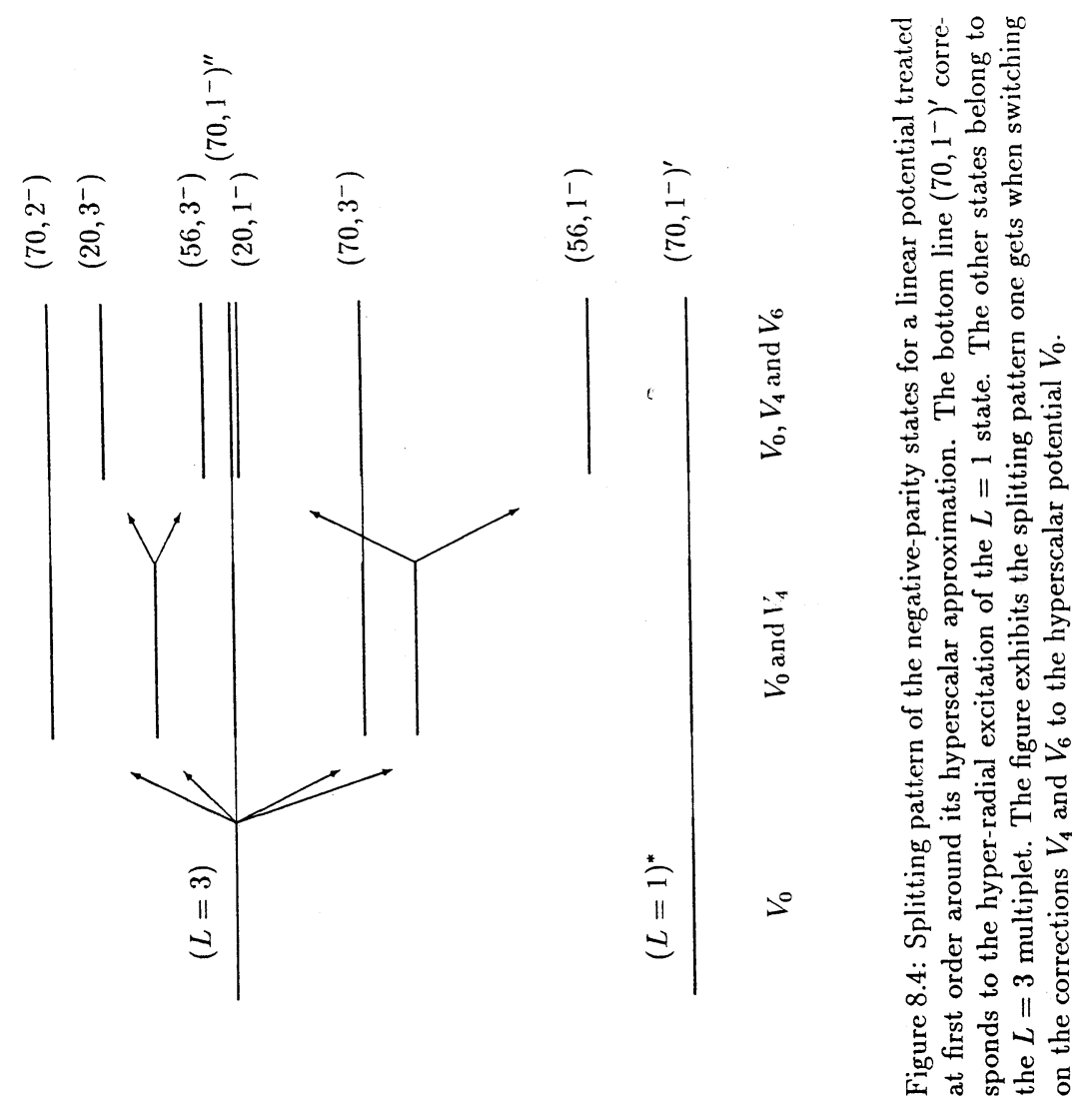

2

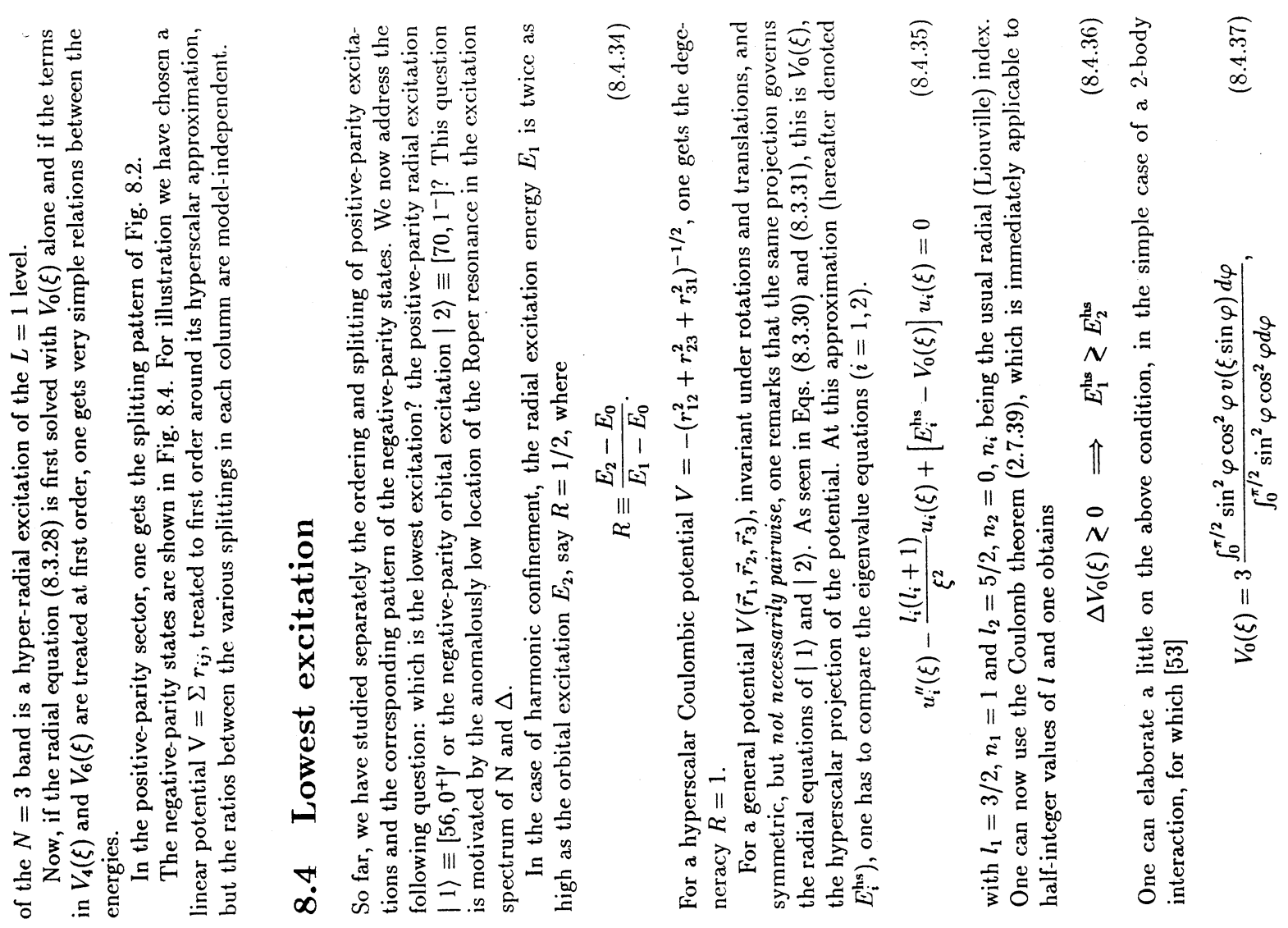



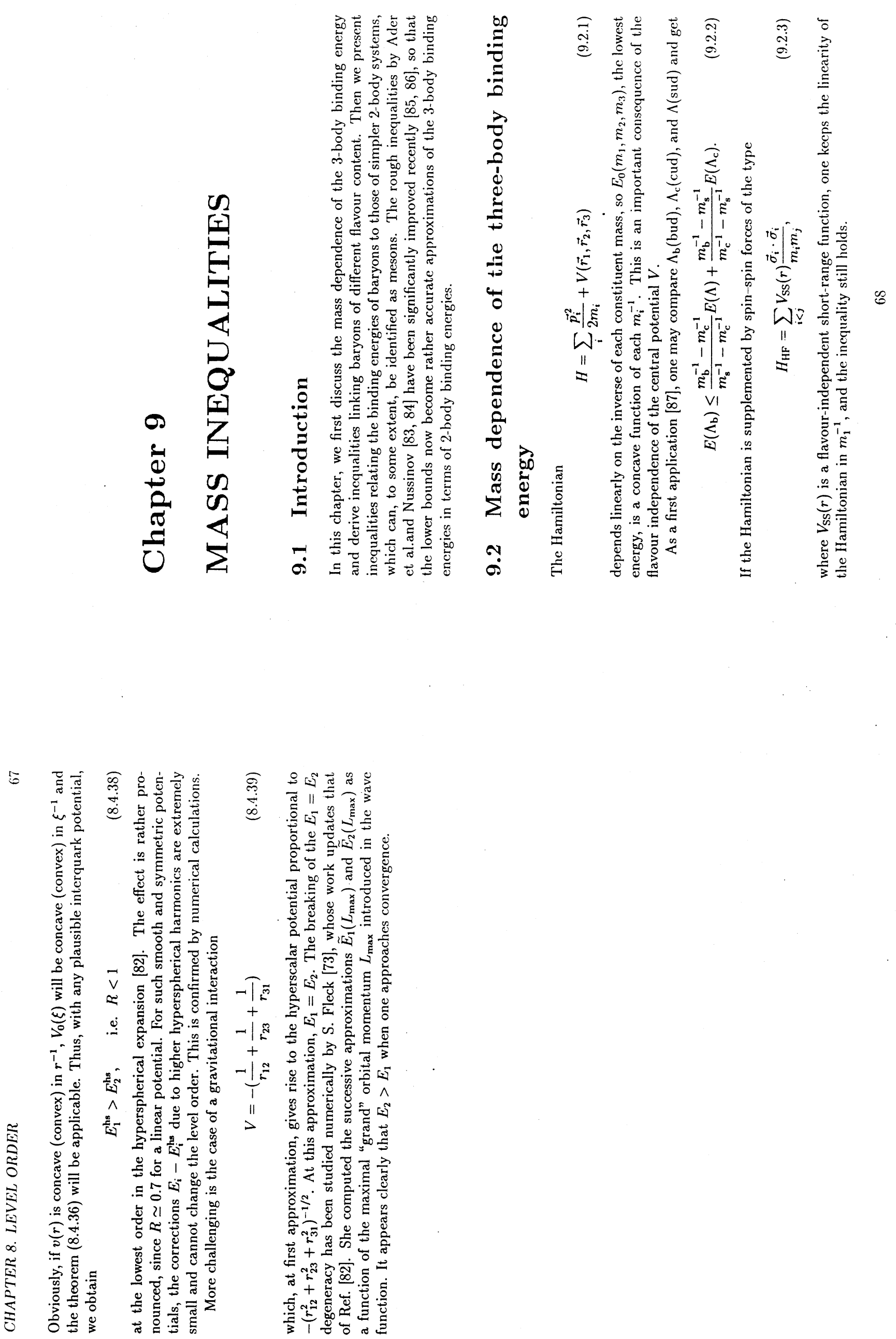


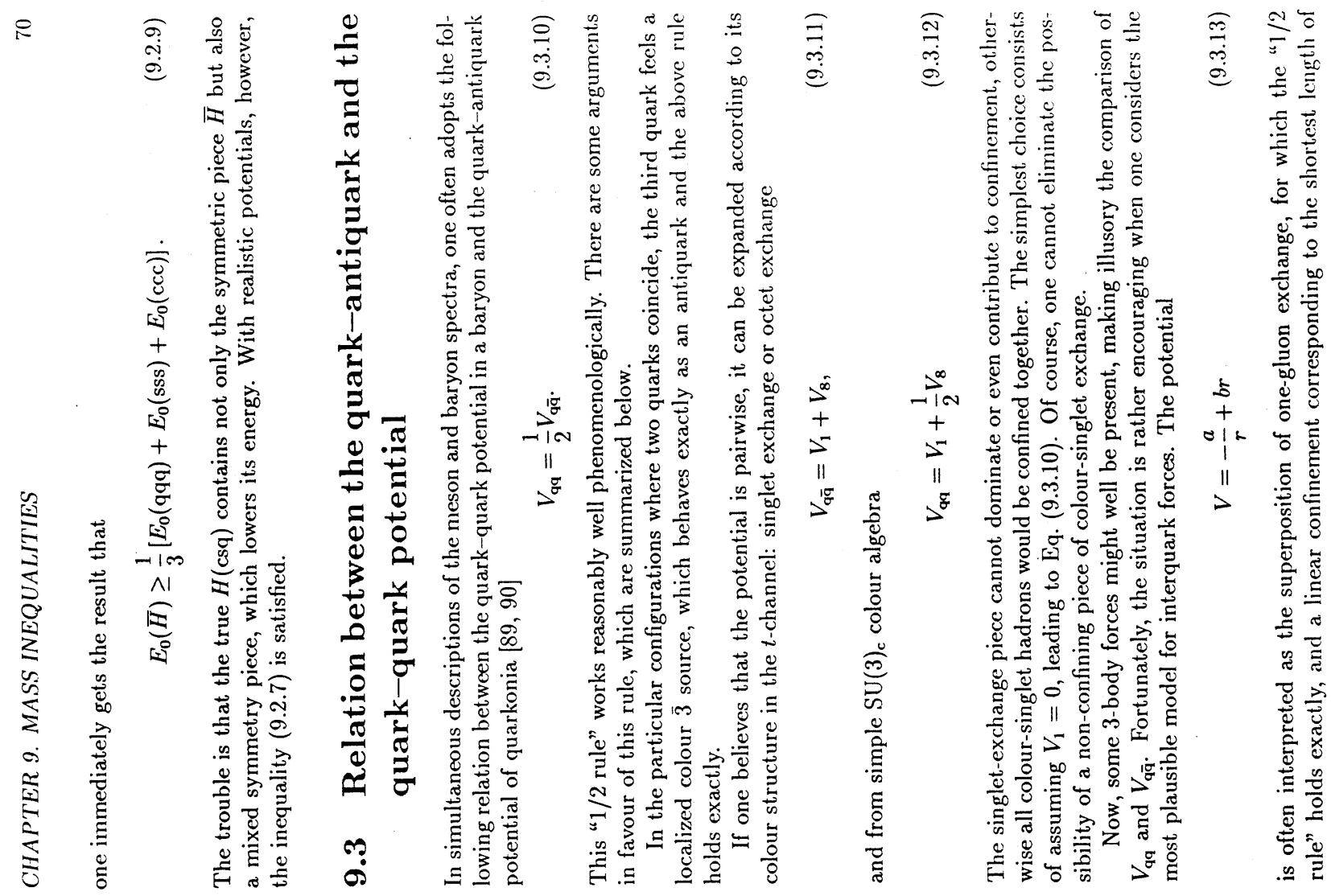

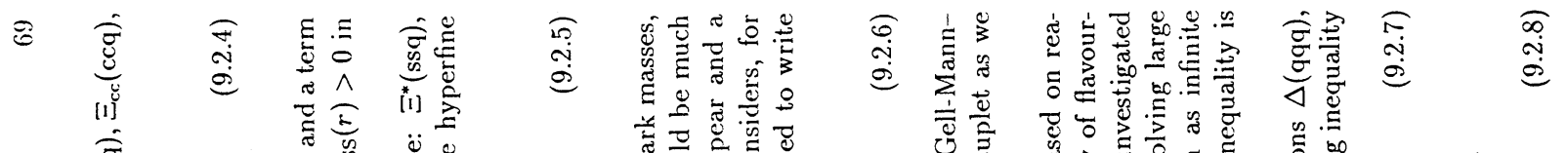

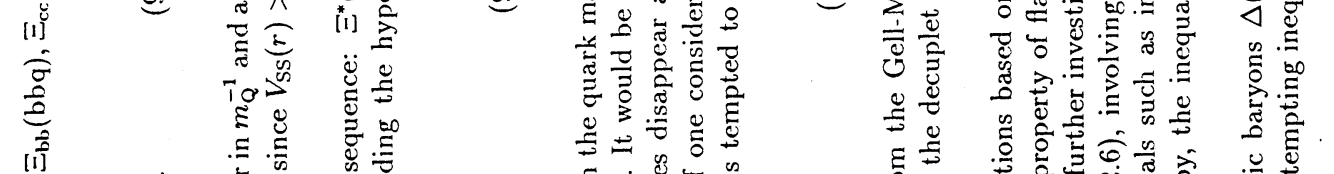

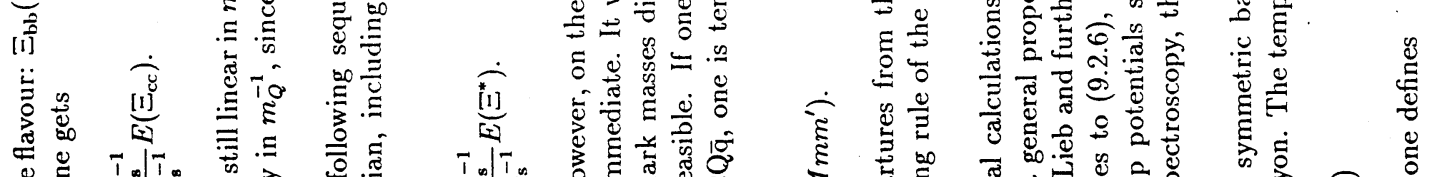

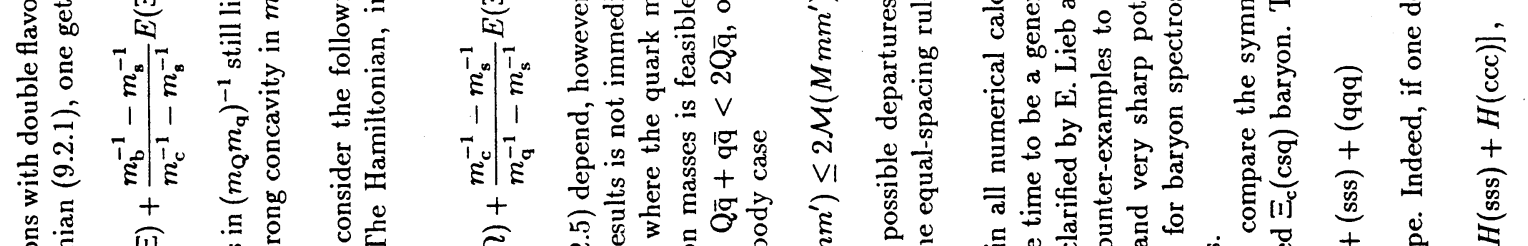

1.

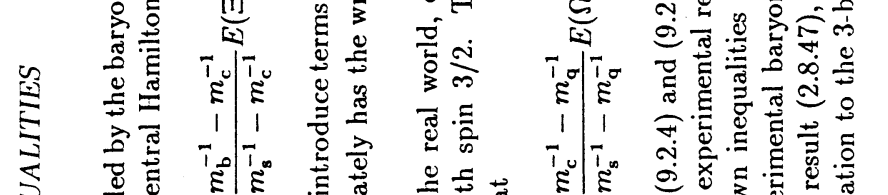

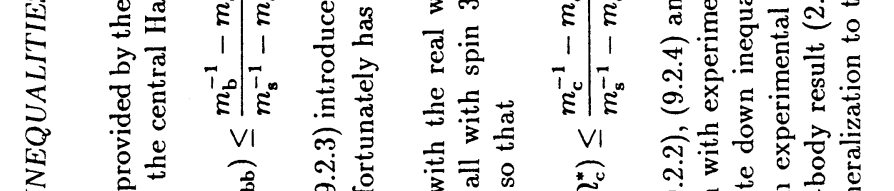

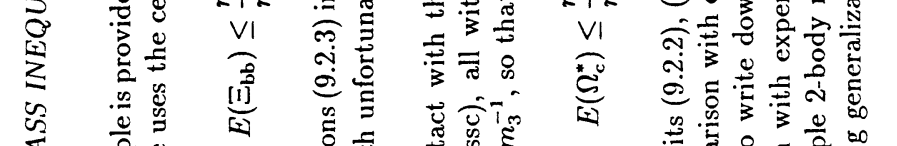

年

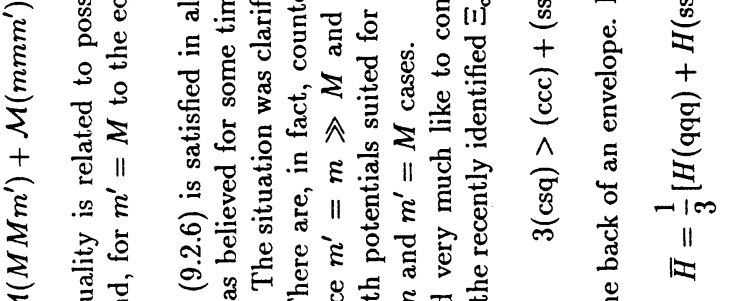

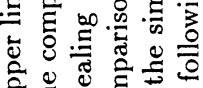

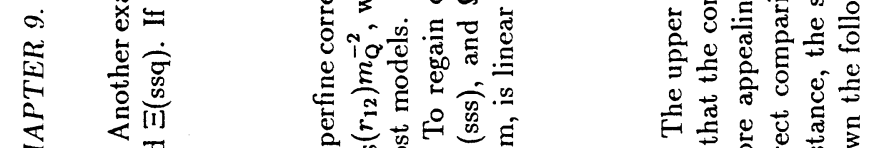

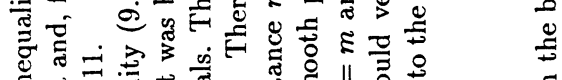

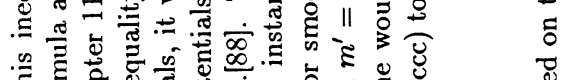

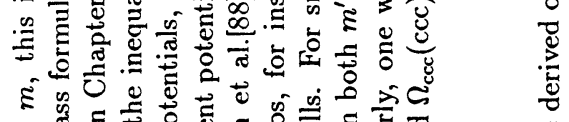

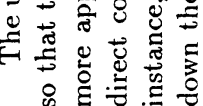

II

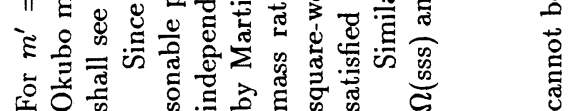




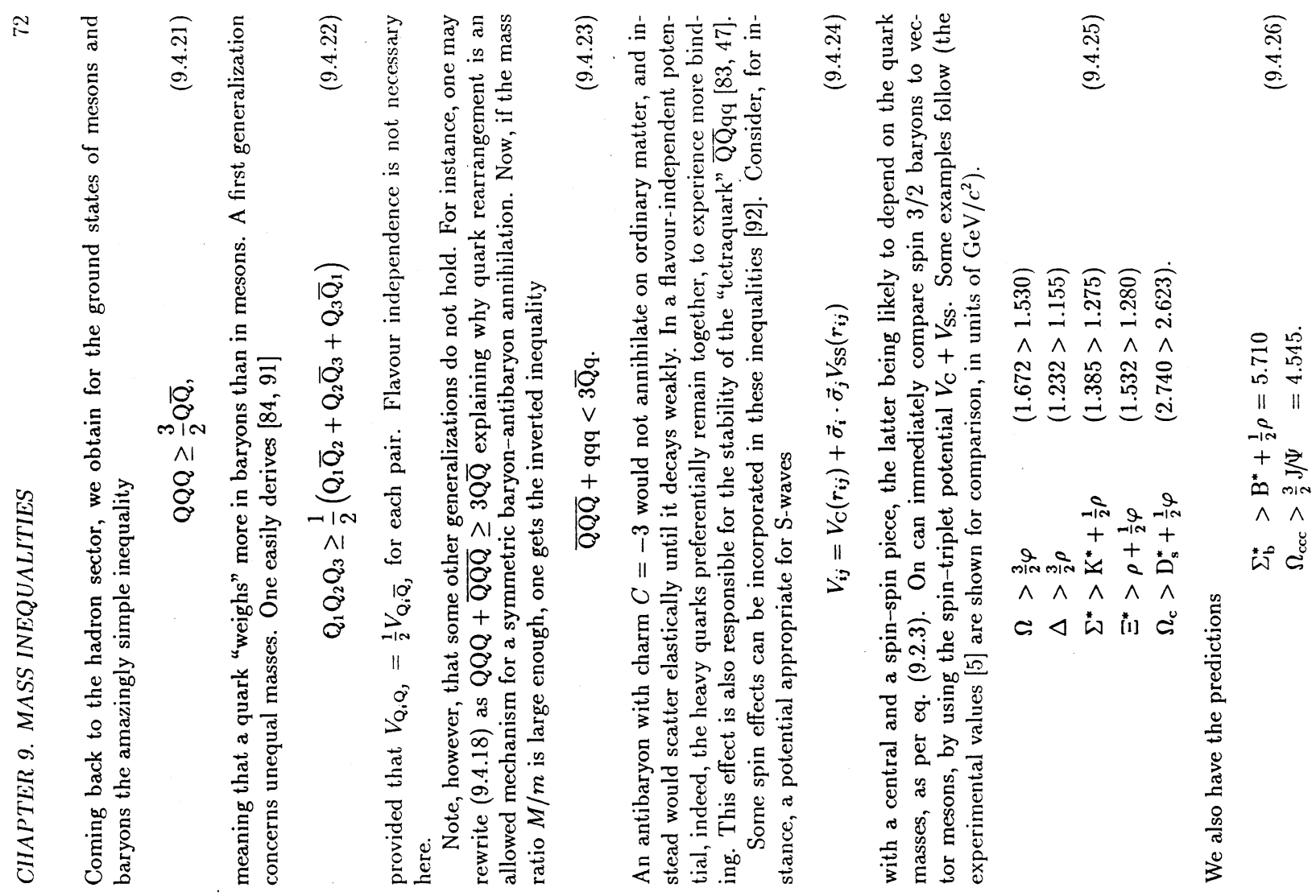

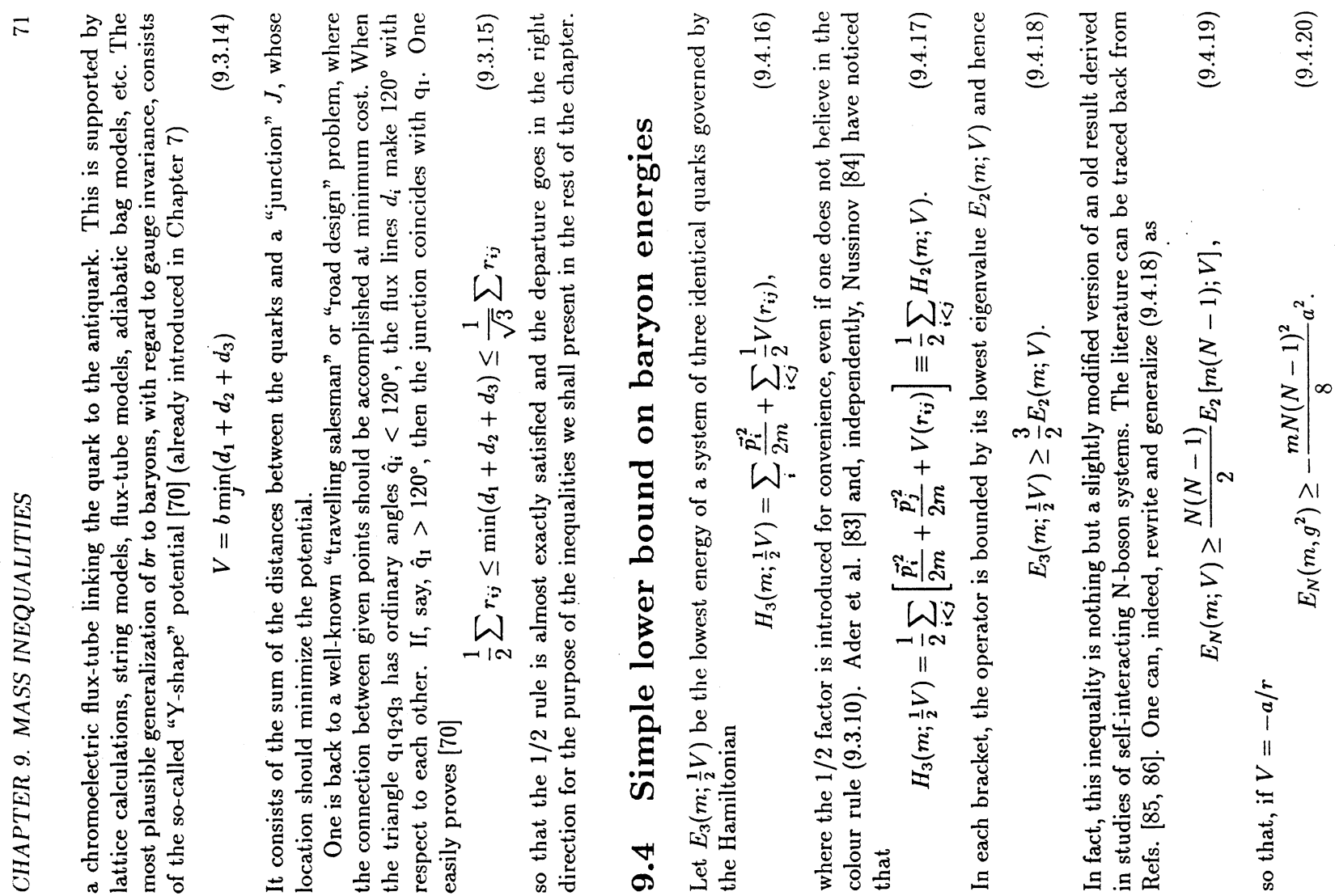




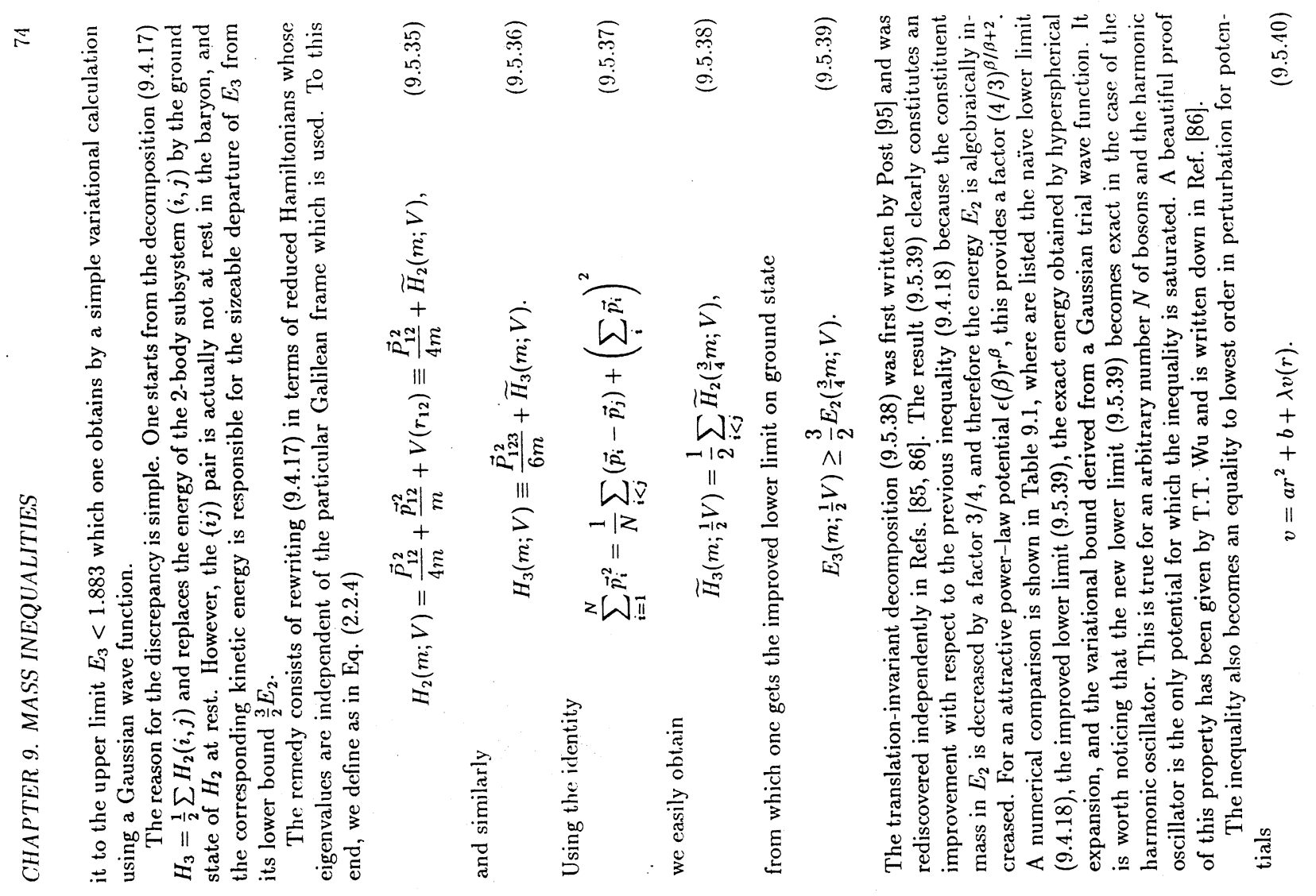

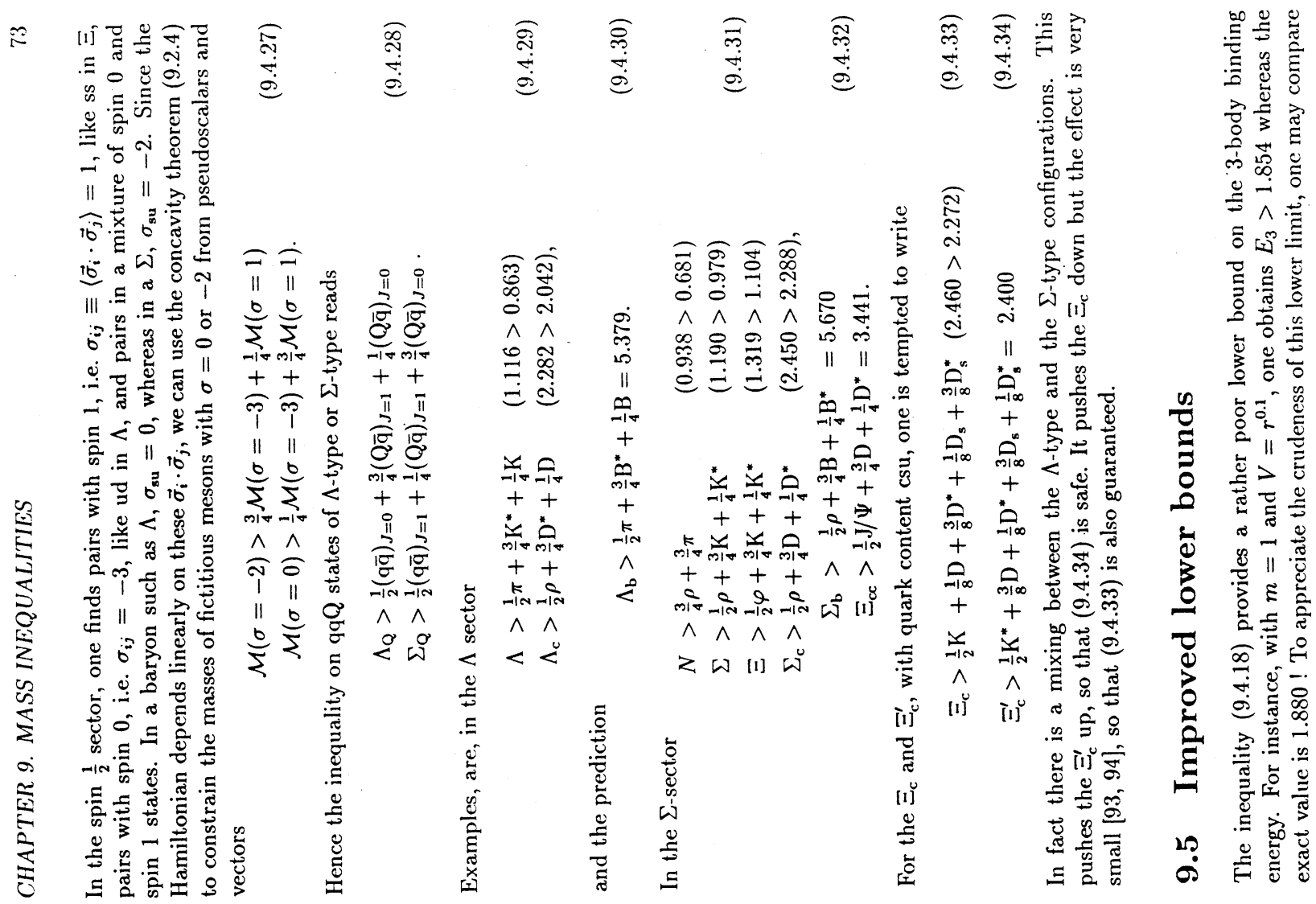



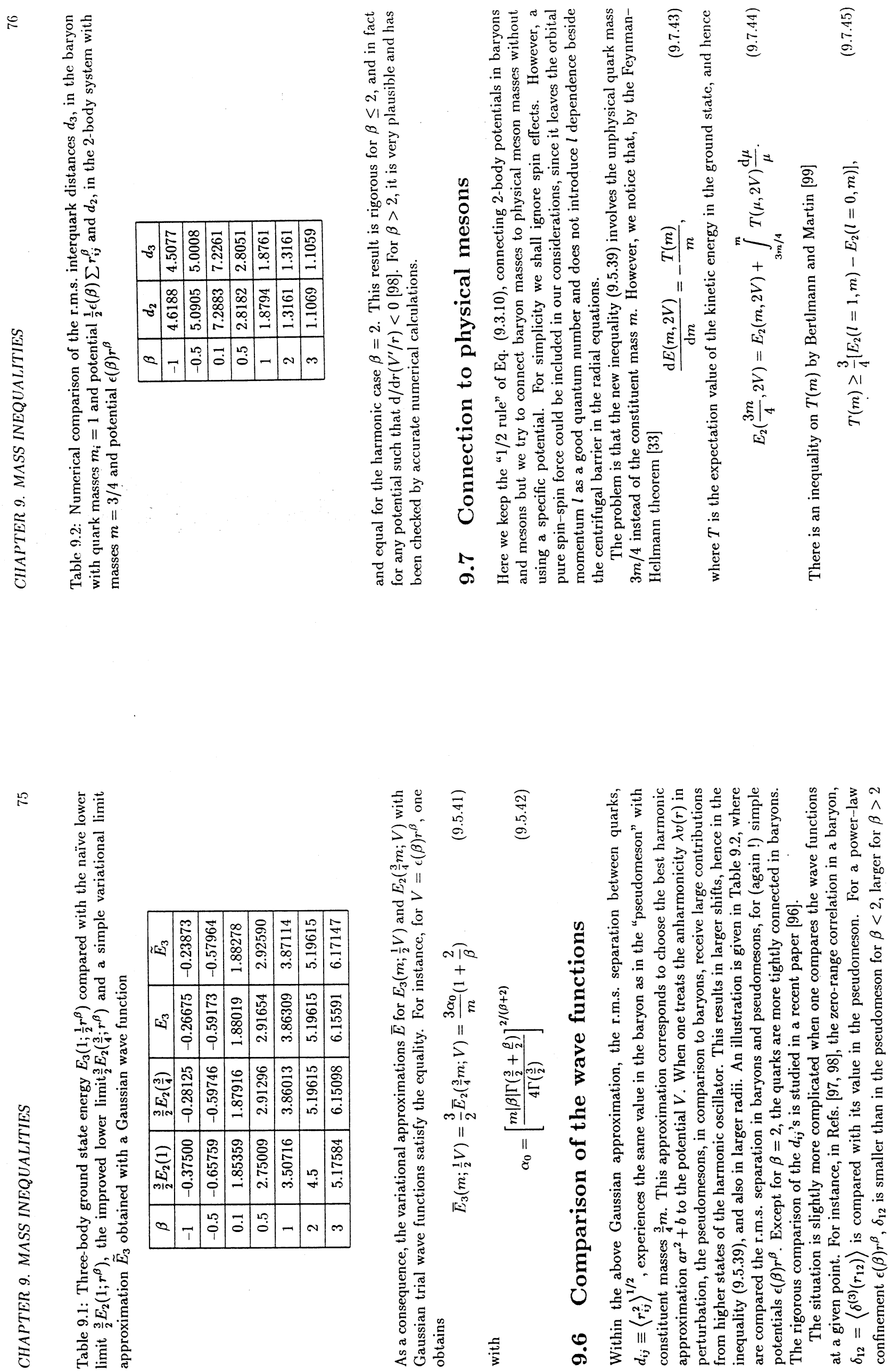


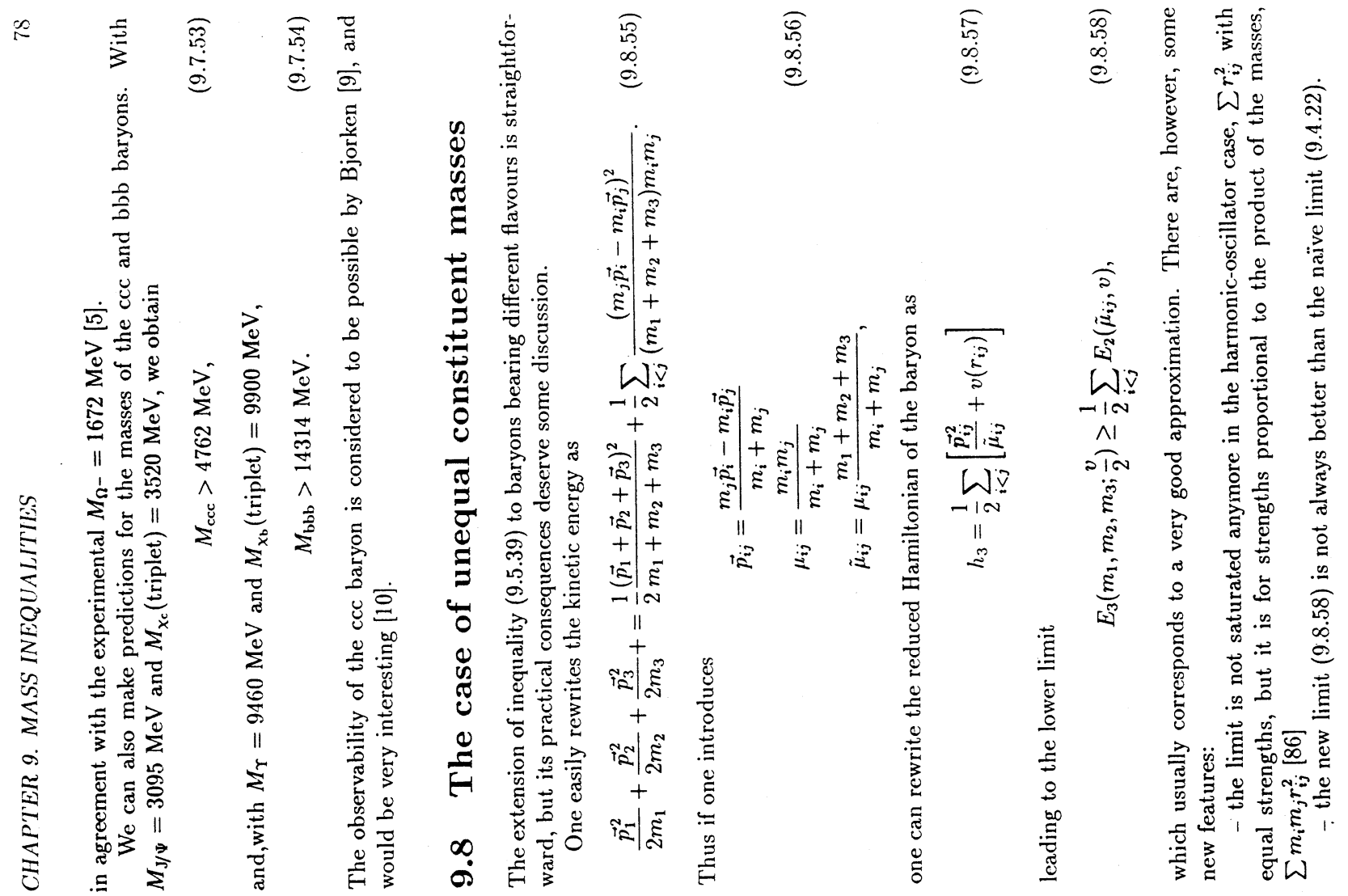

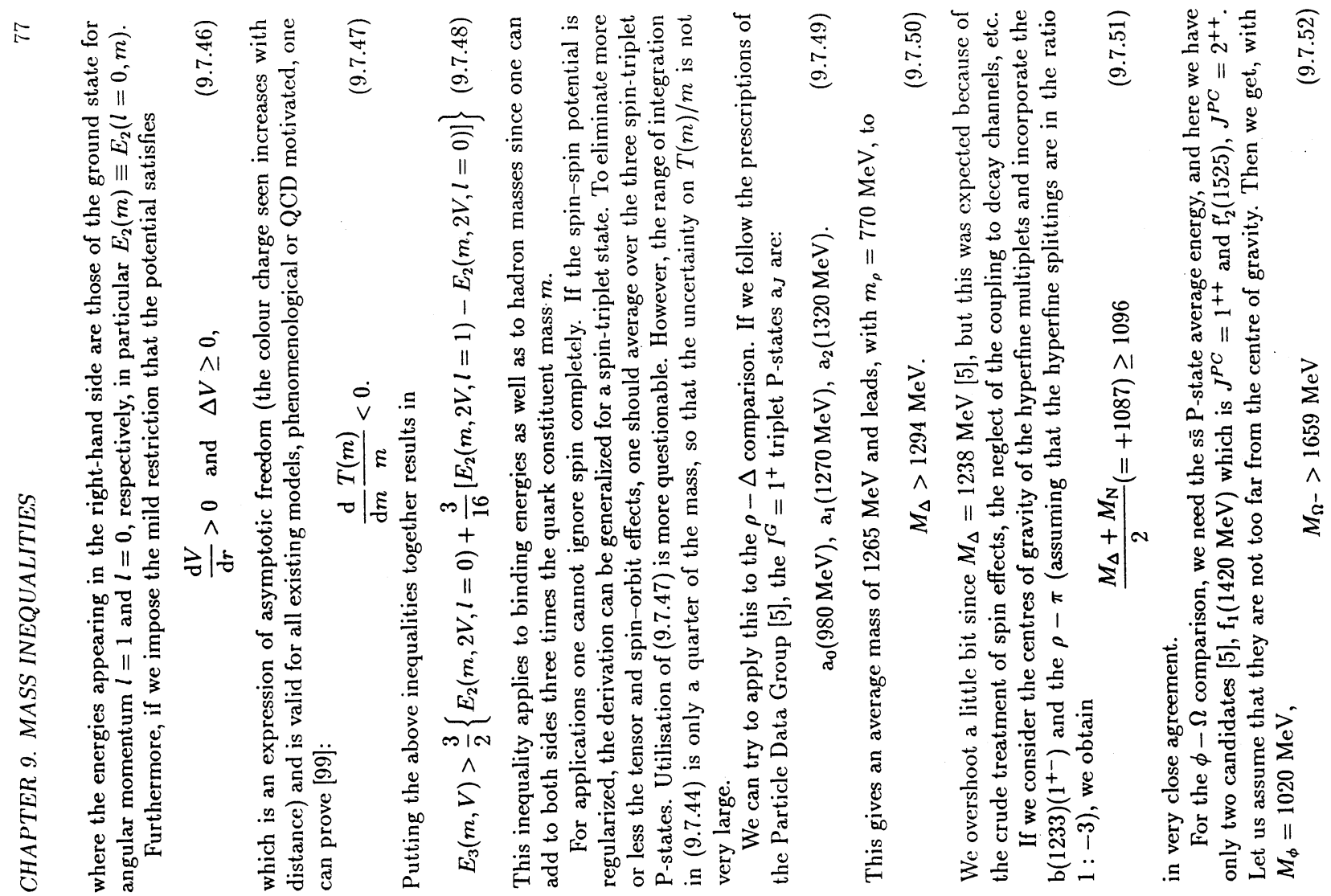




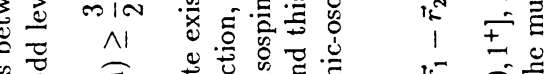

क⿺辶一

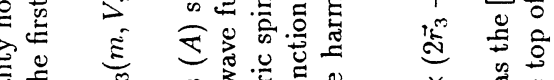

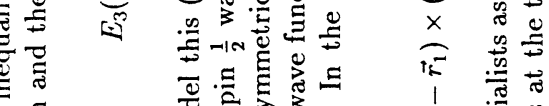

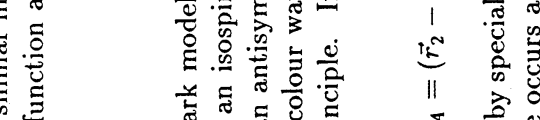

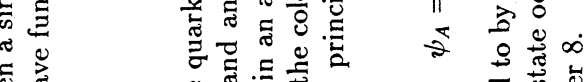

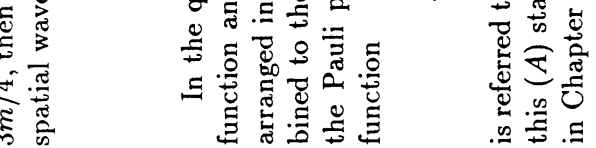

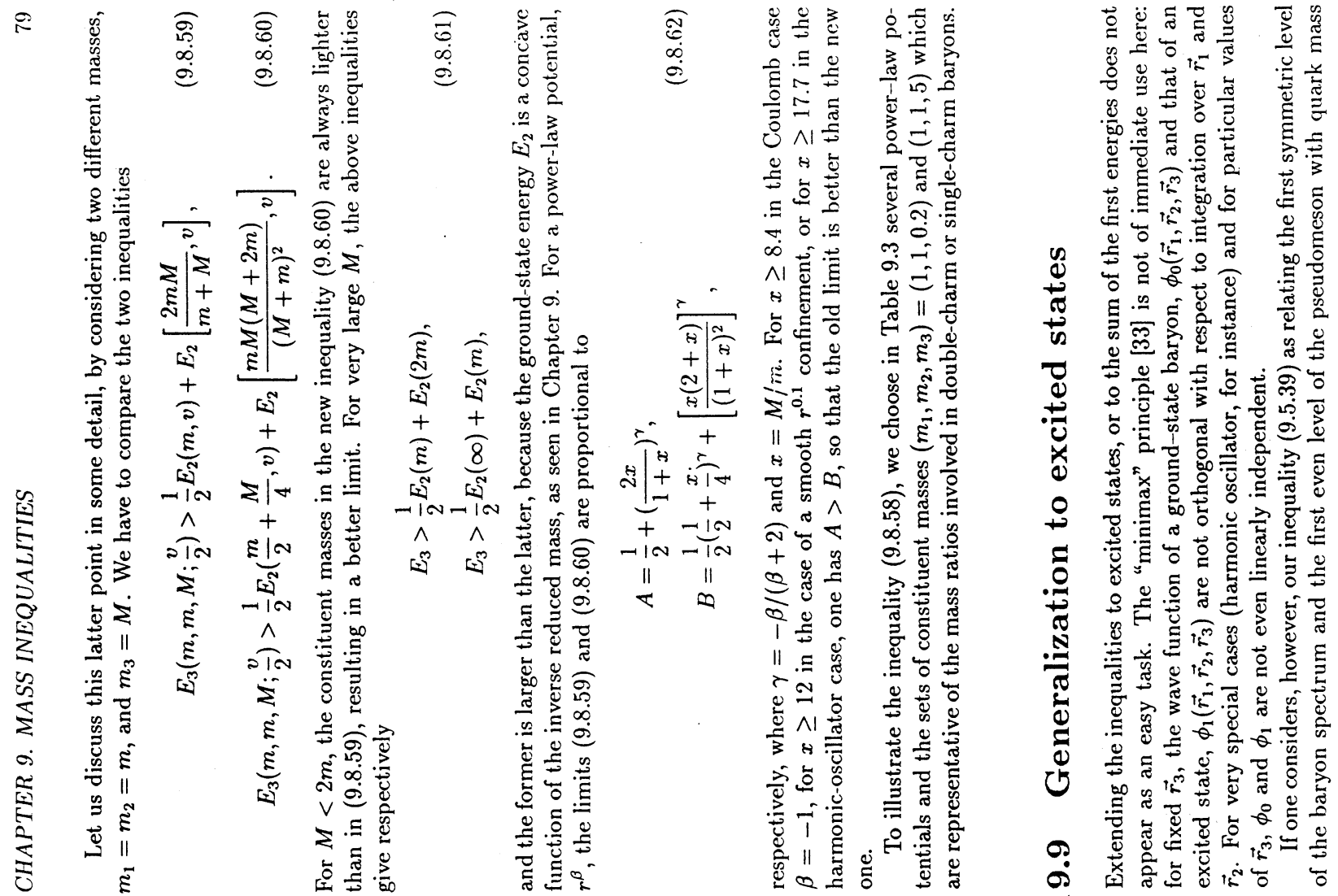



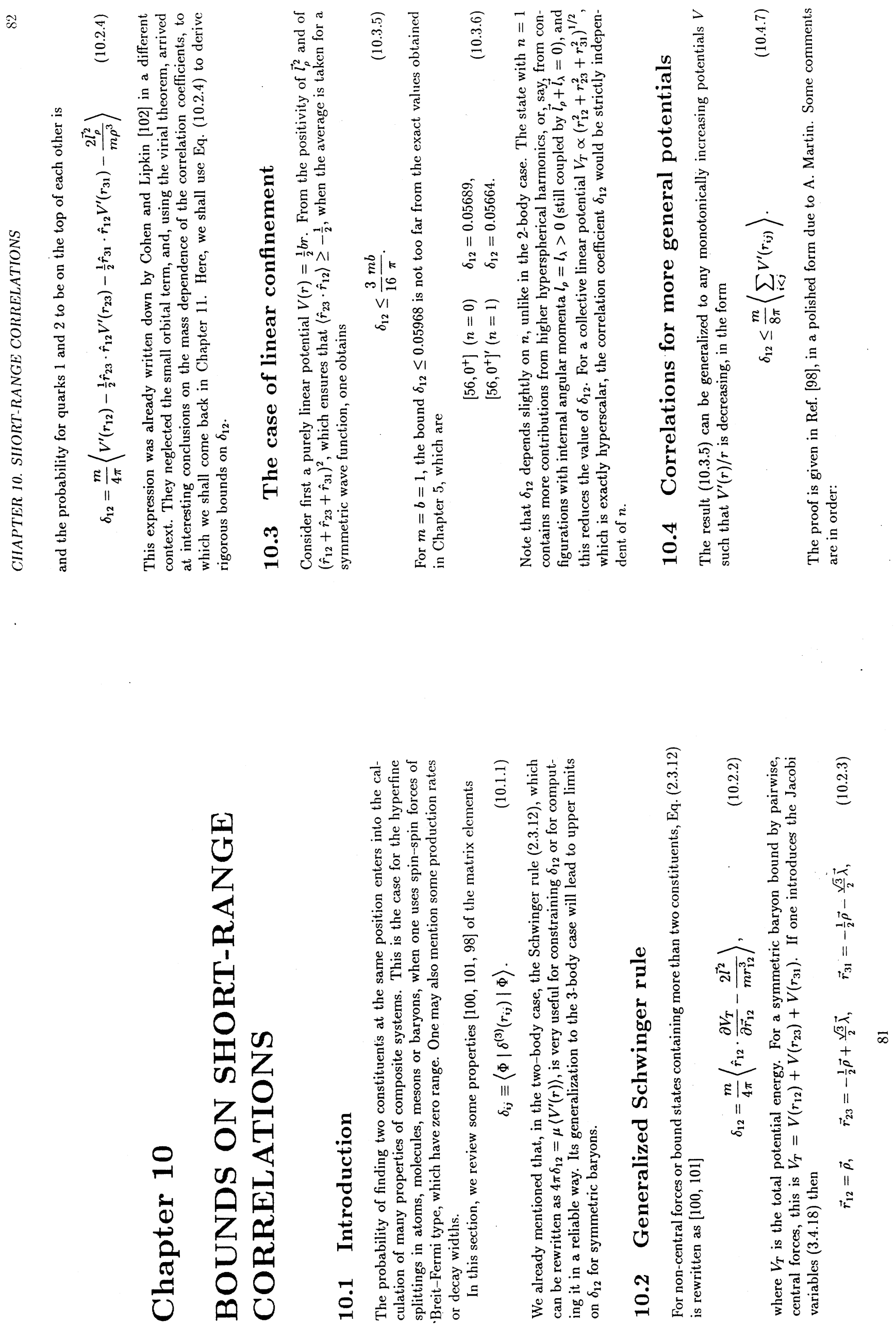

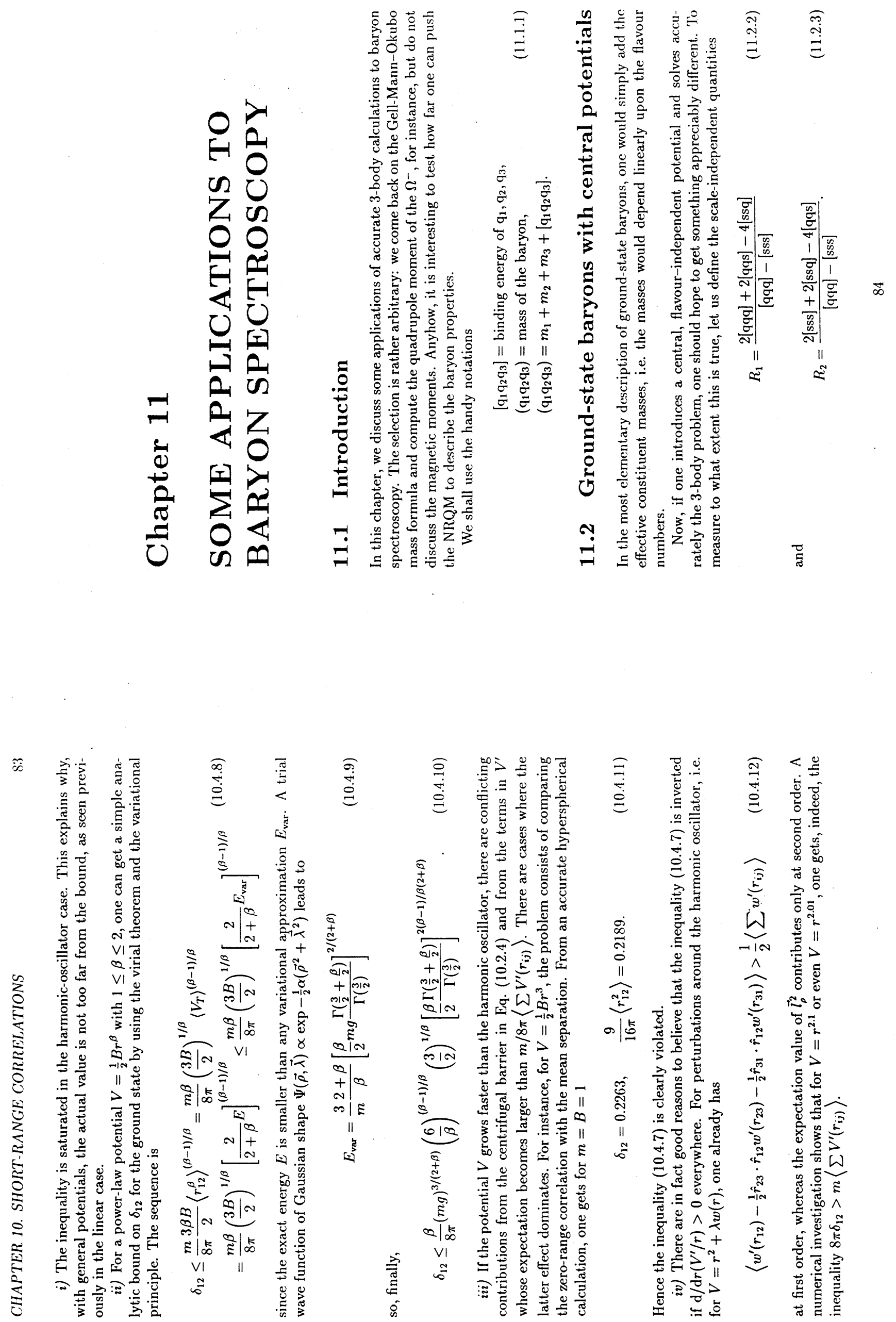

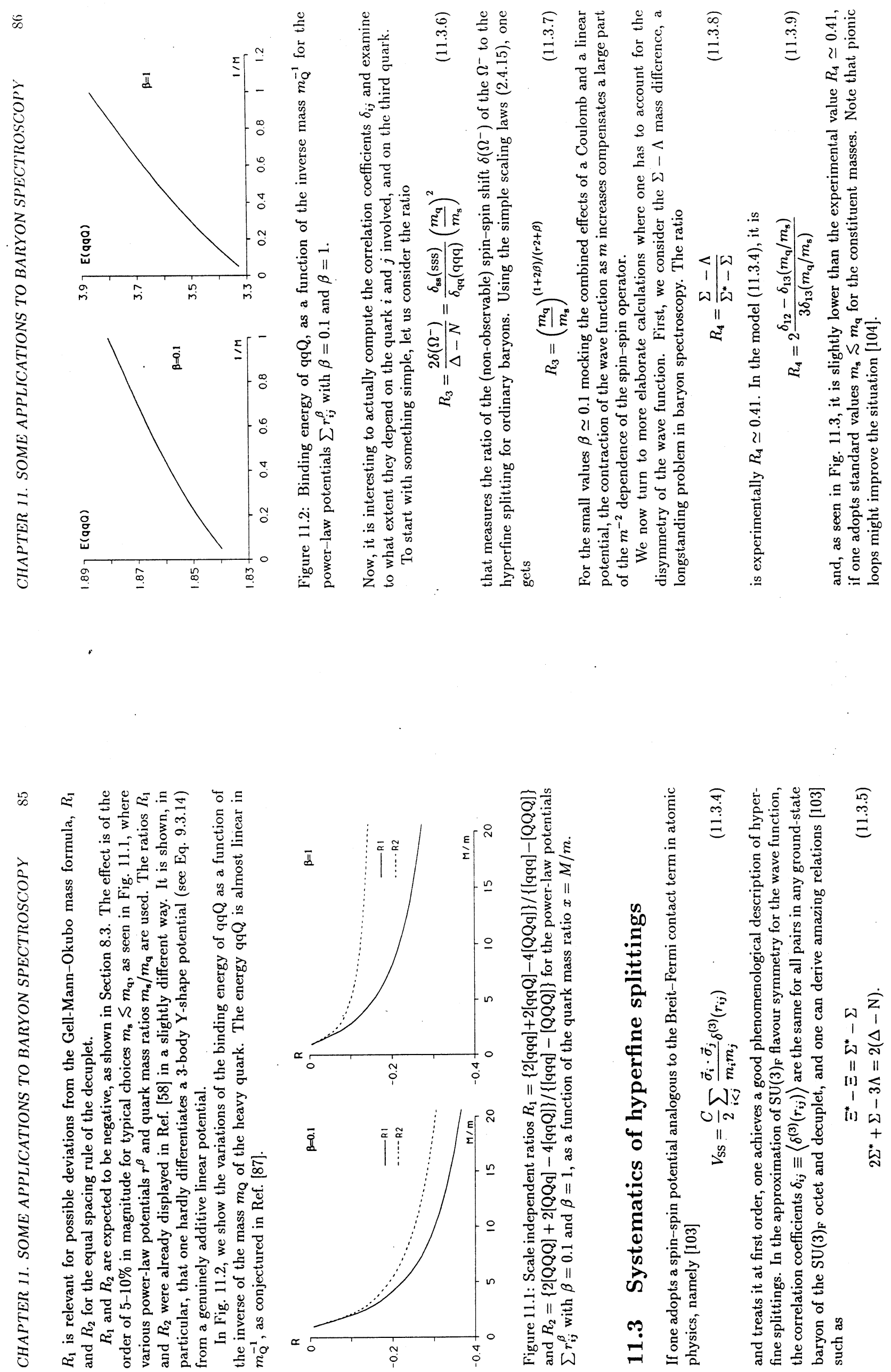

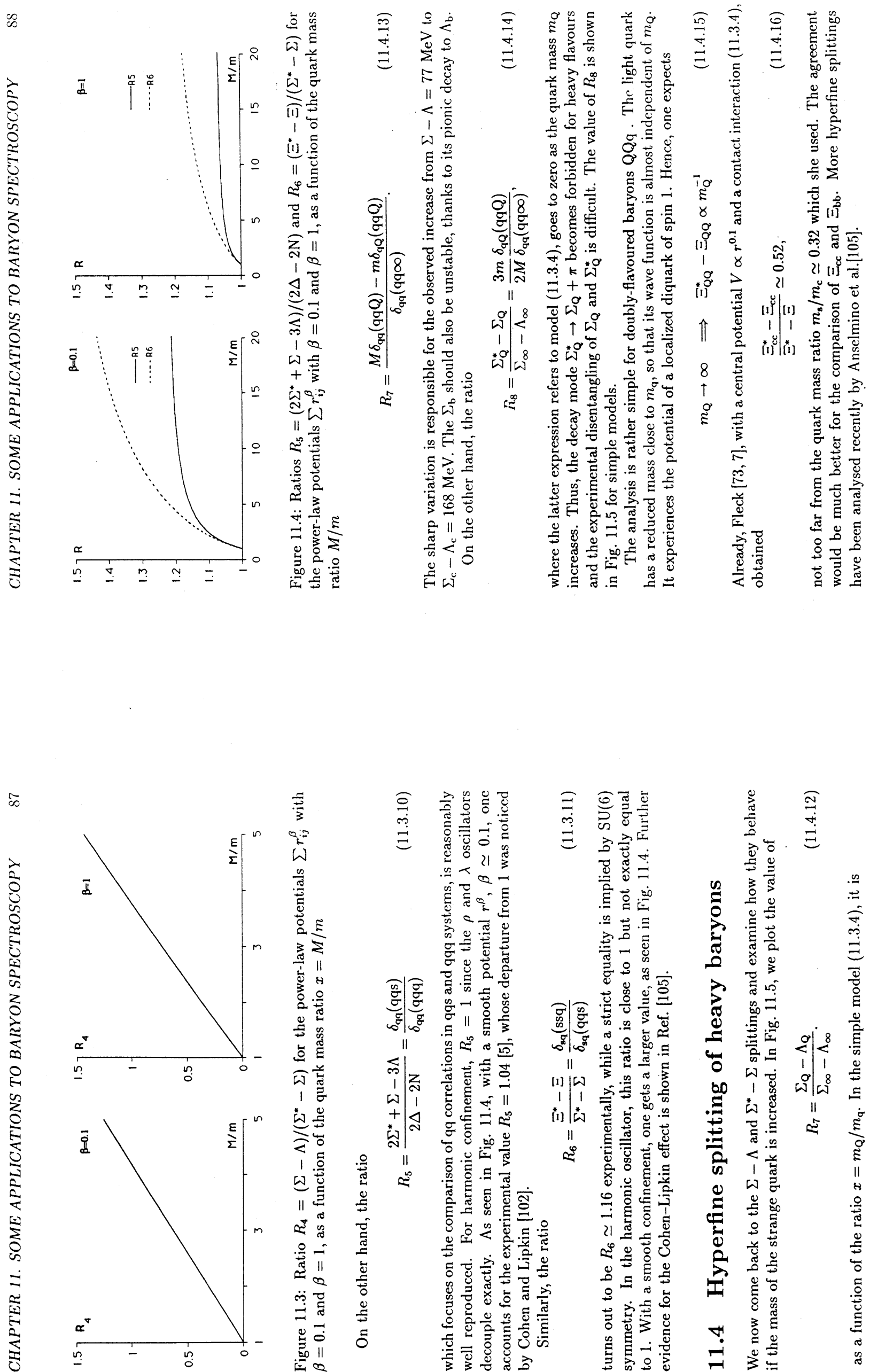

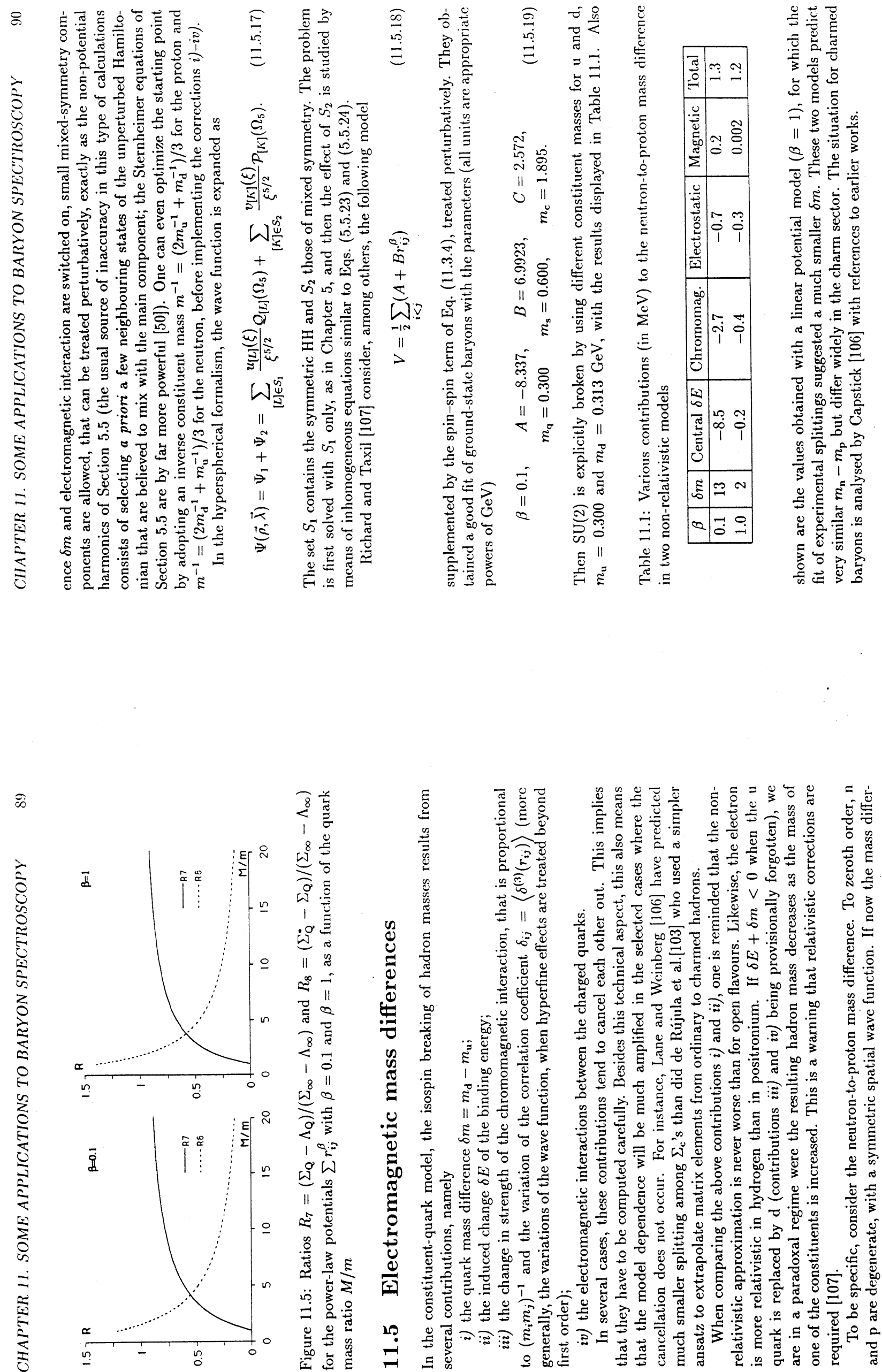

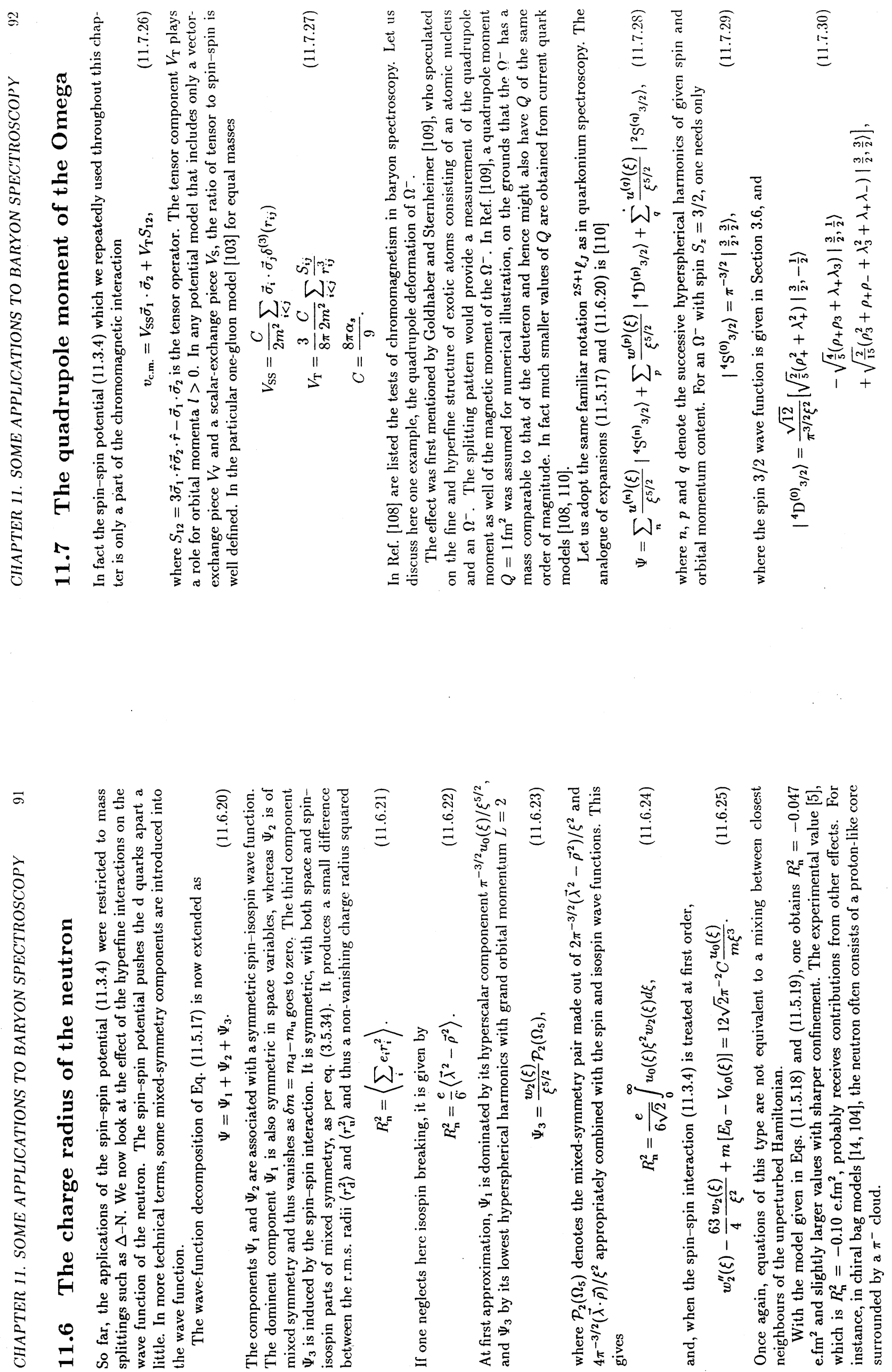

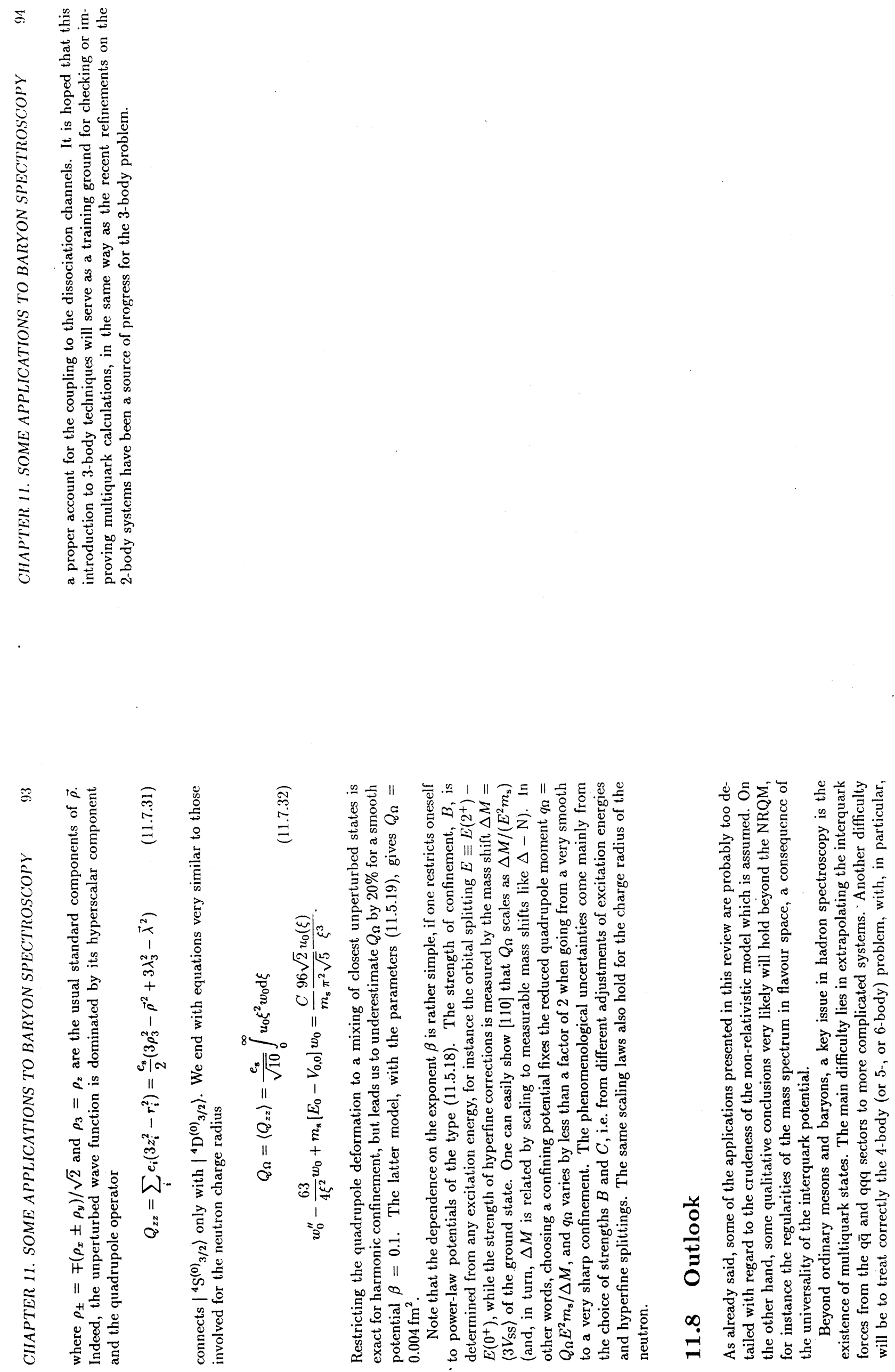

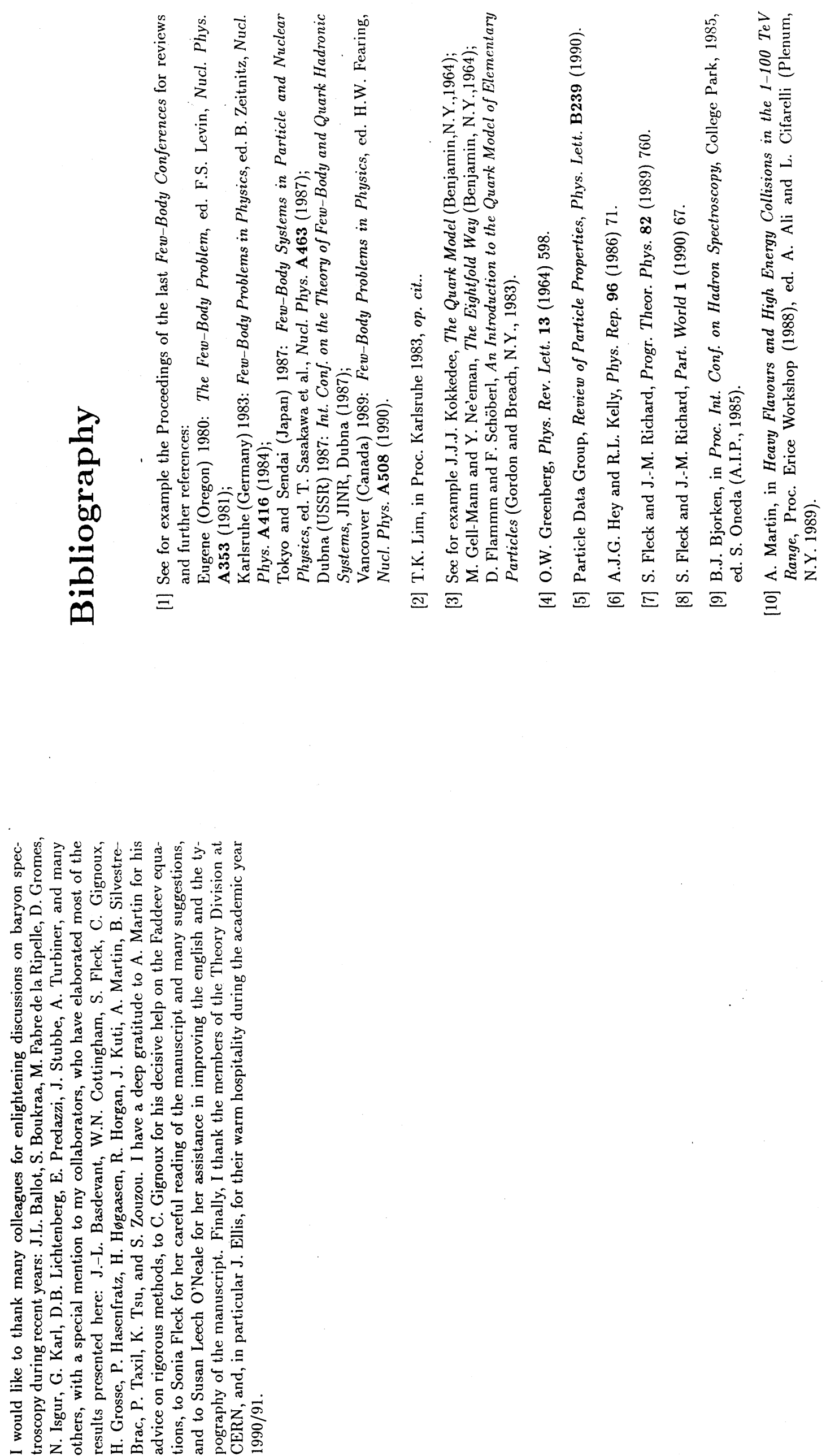

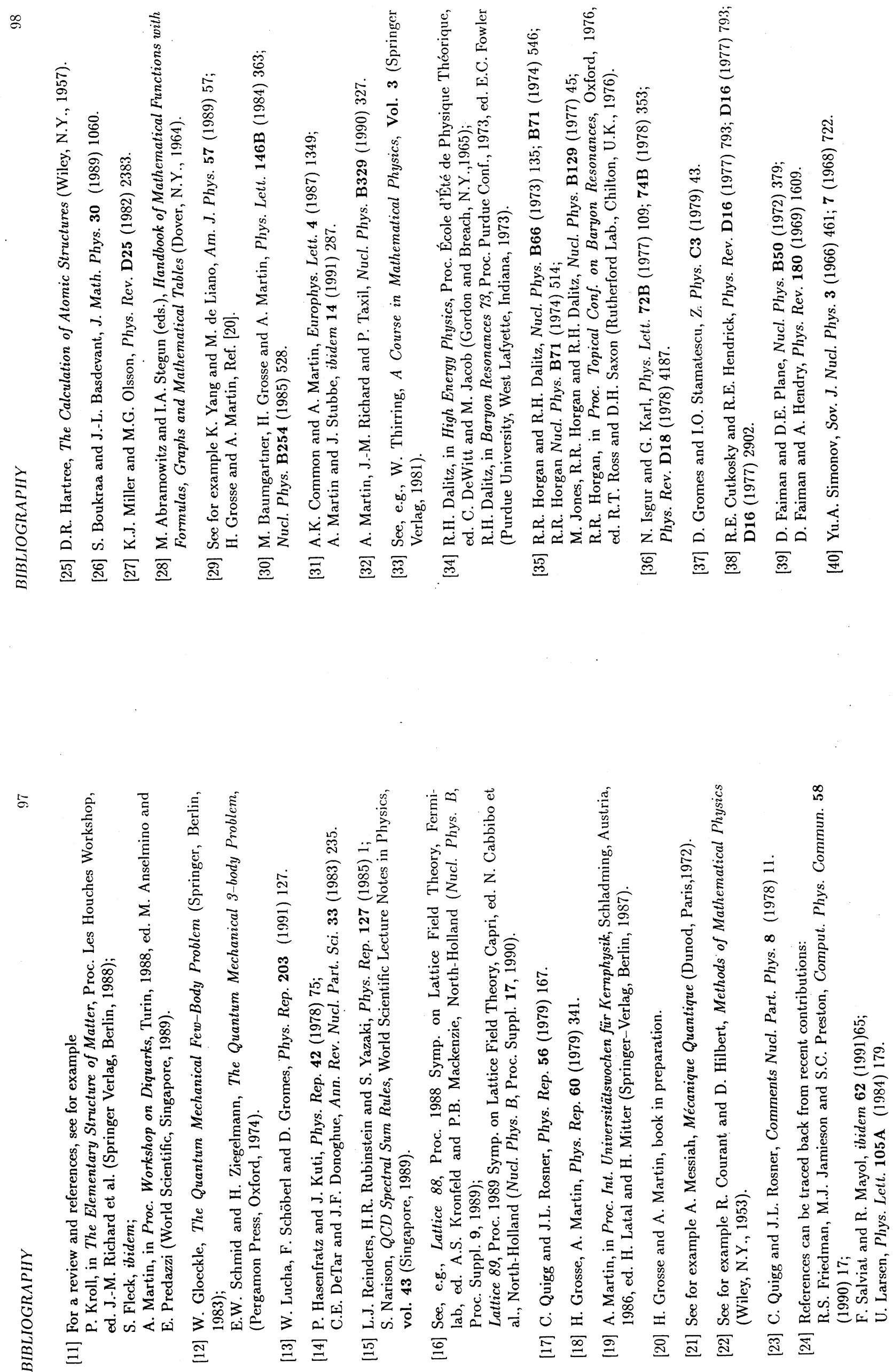


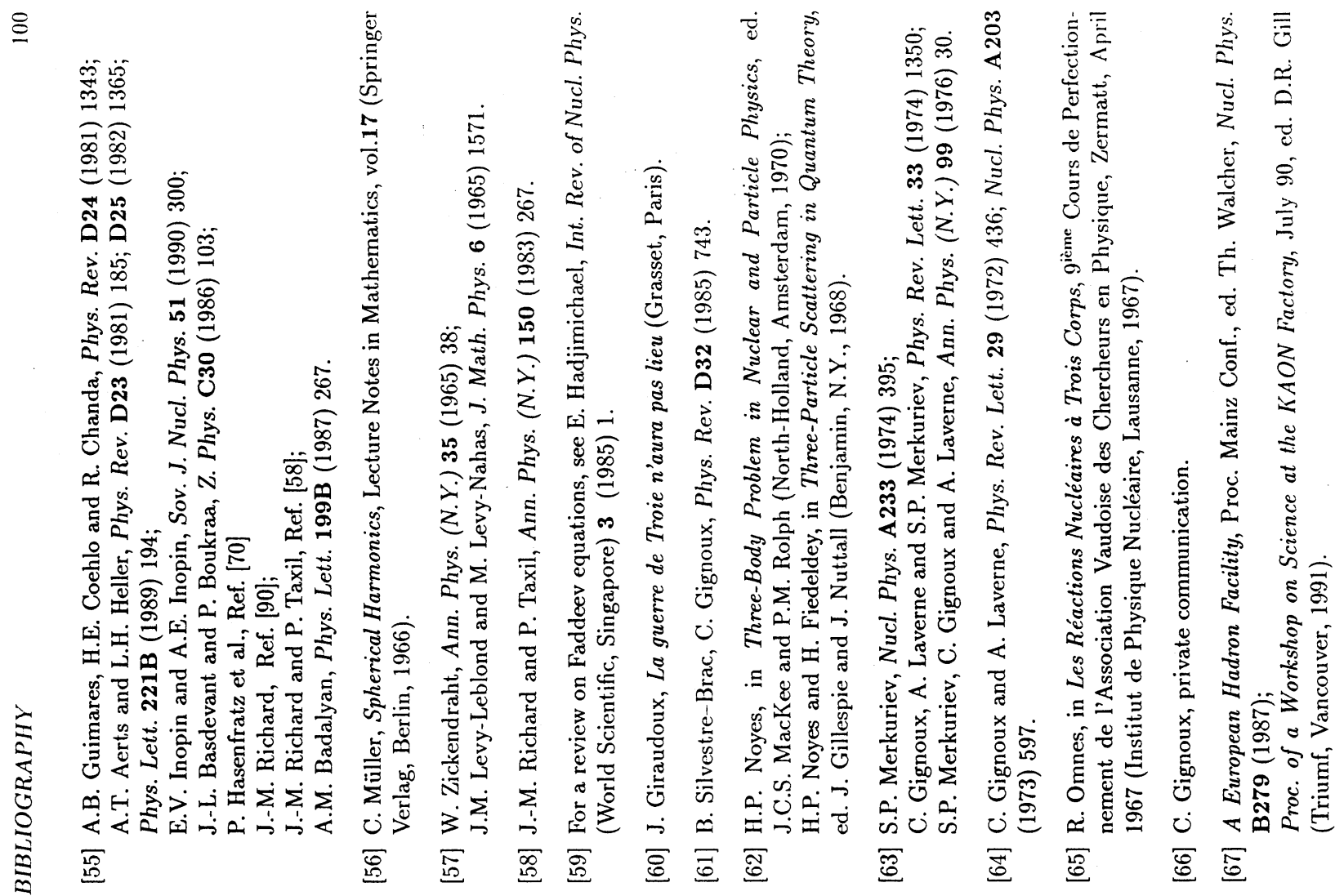

8

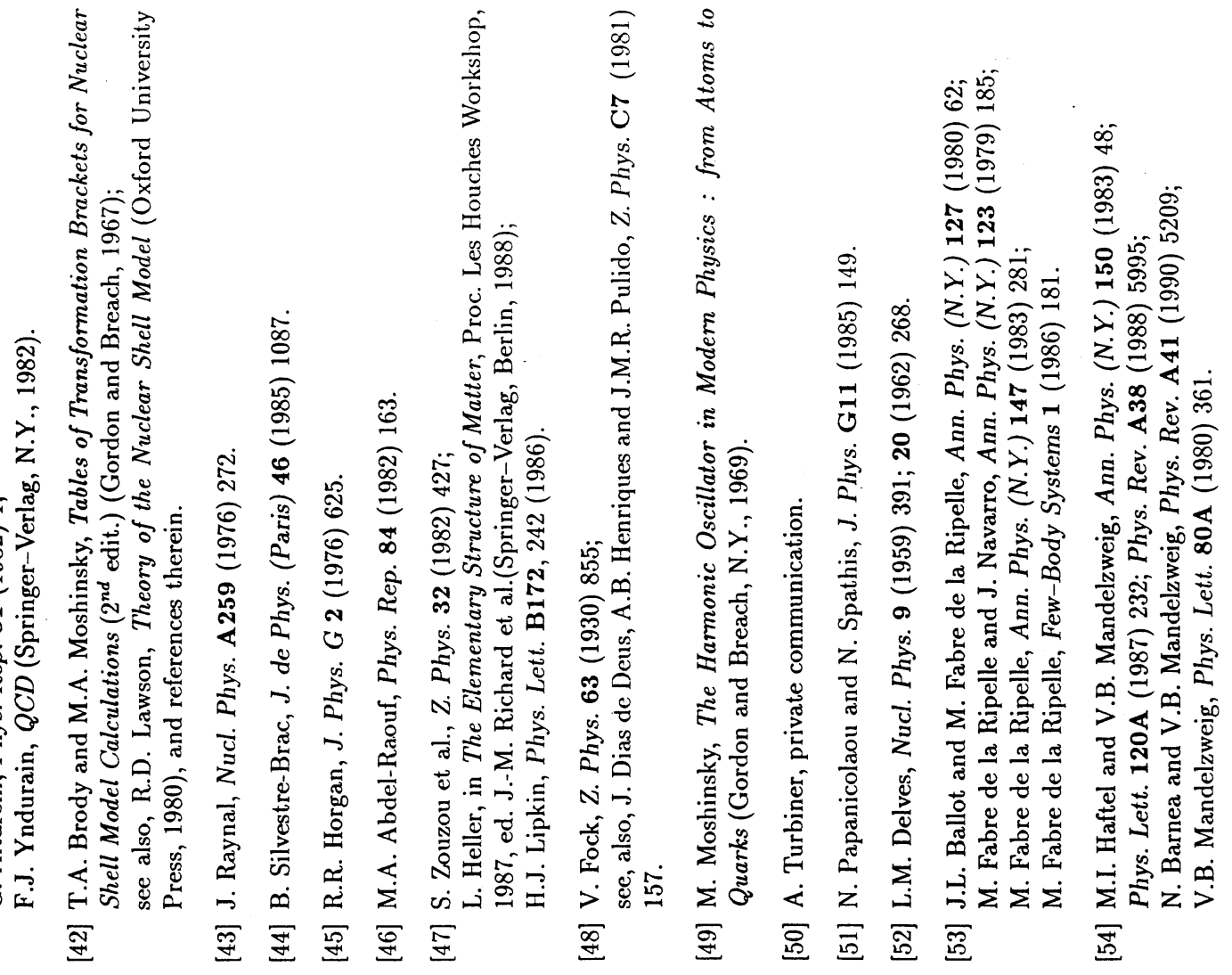



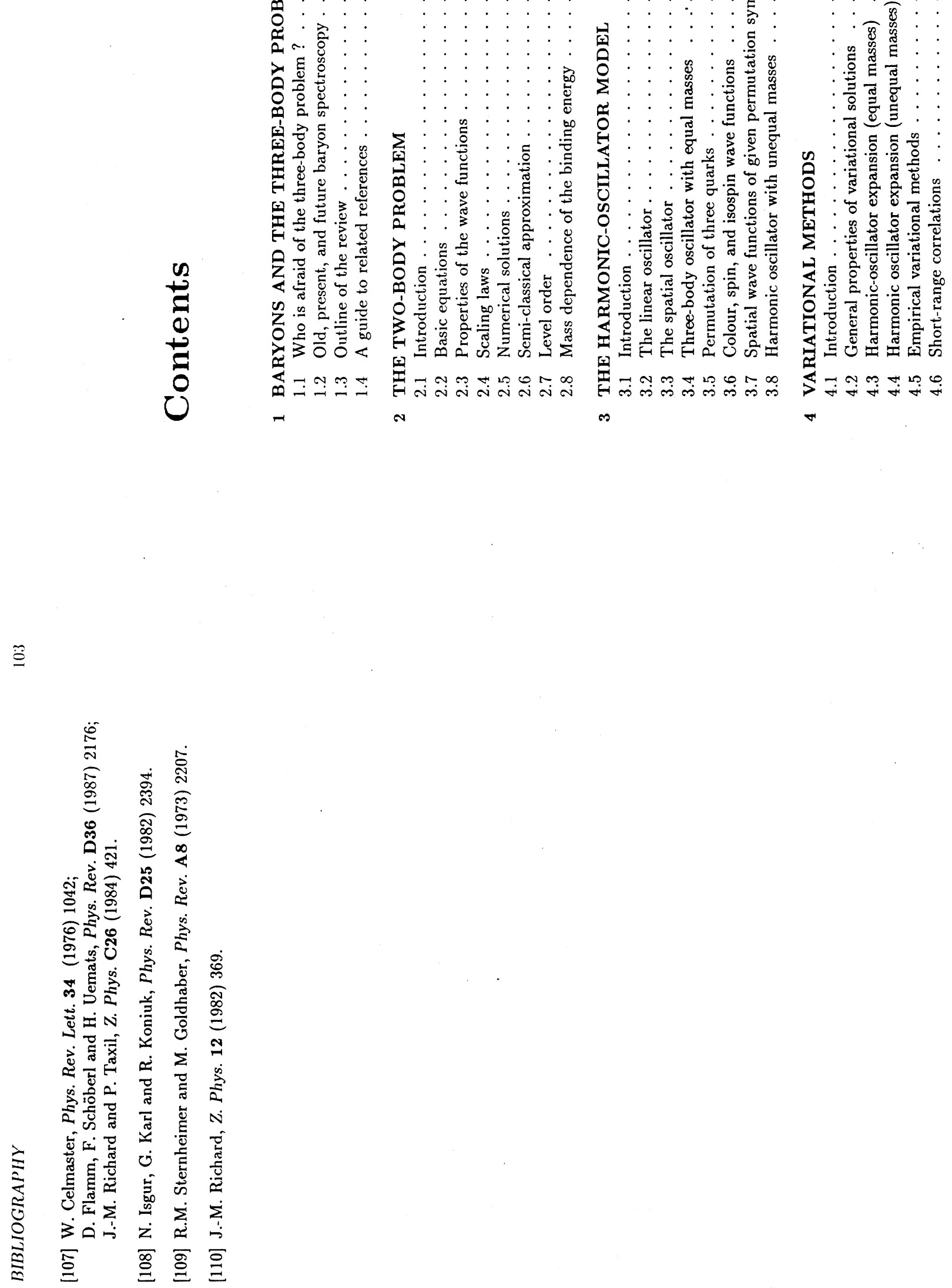


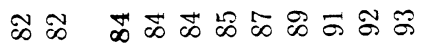

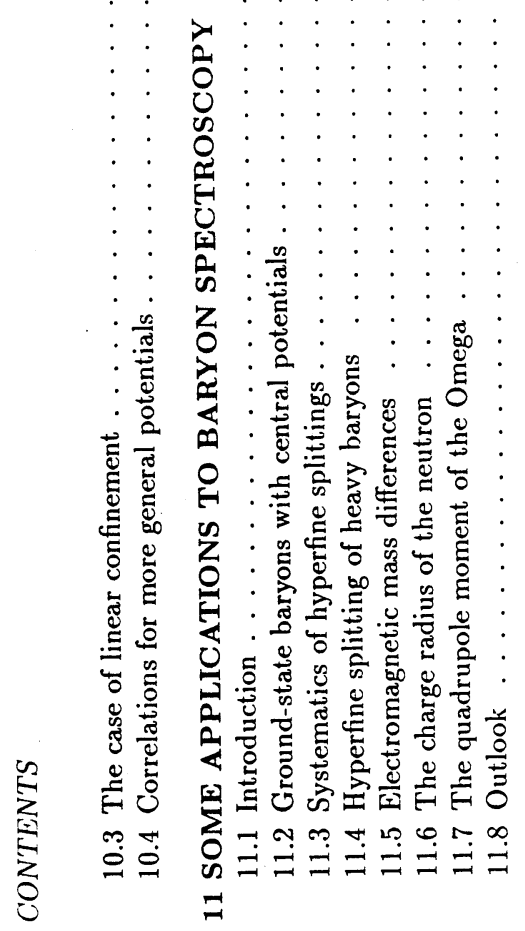

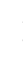

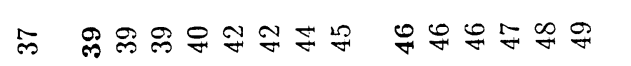

농

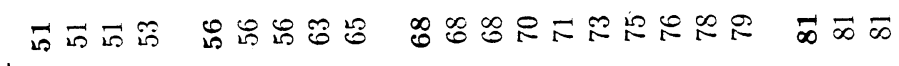
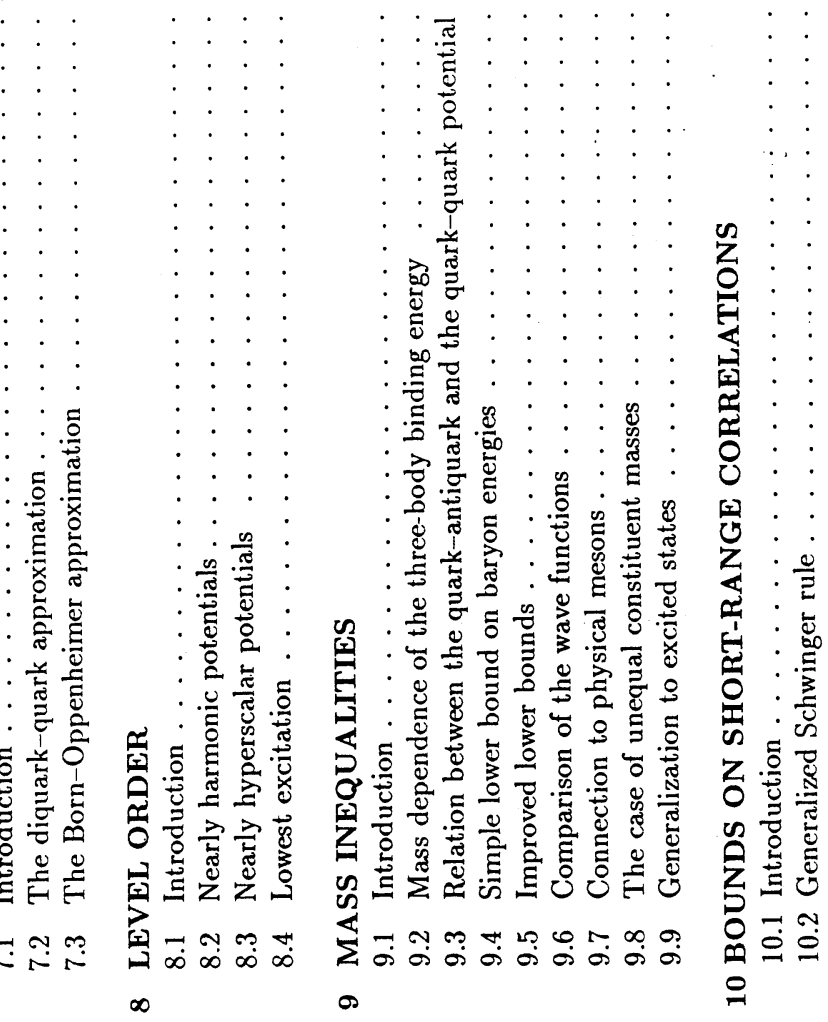


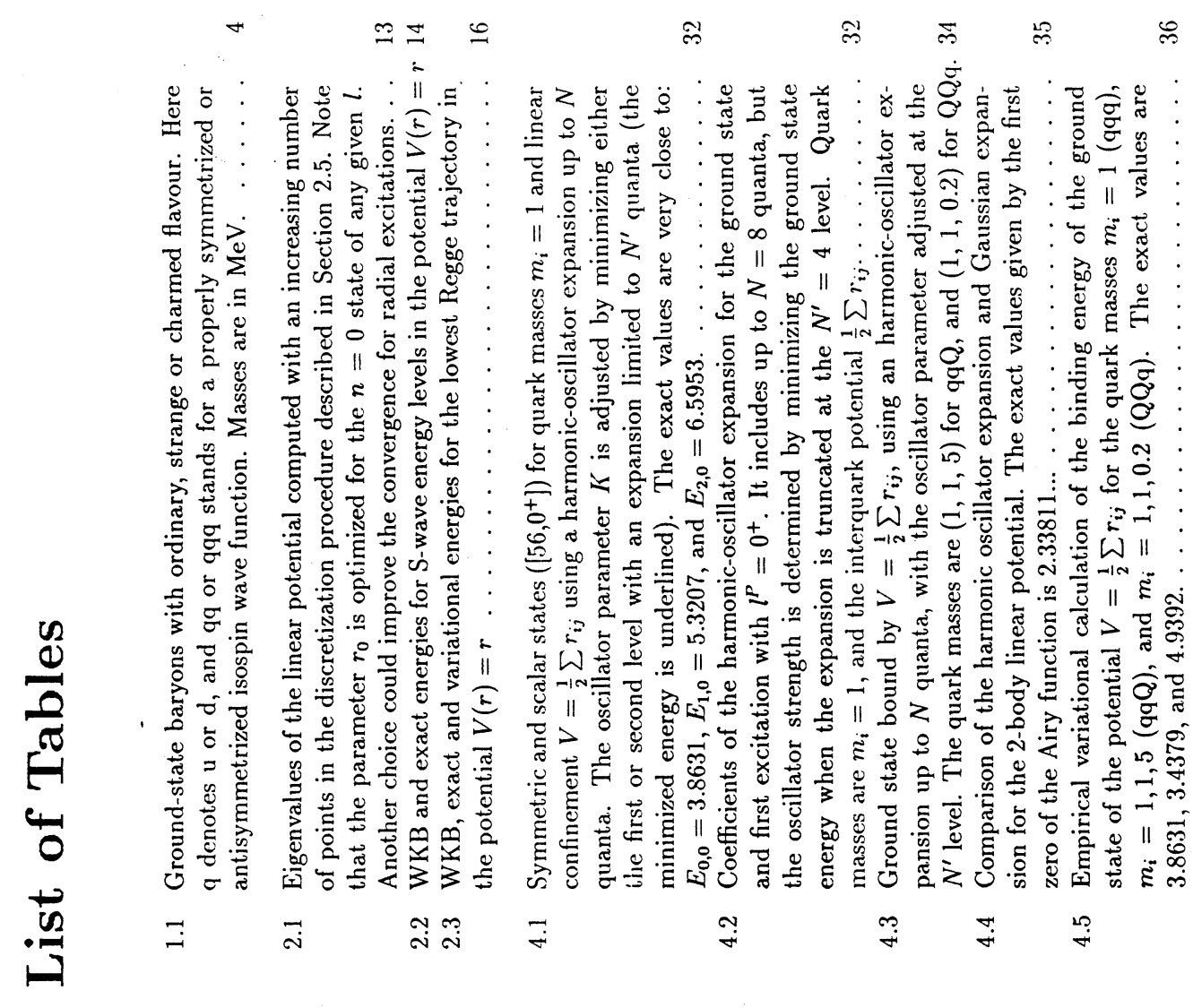

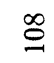

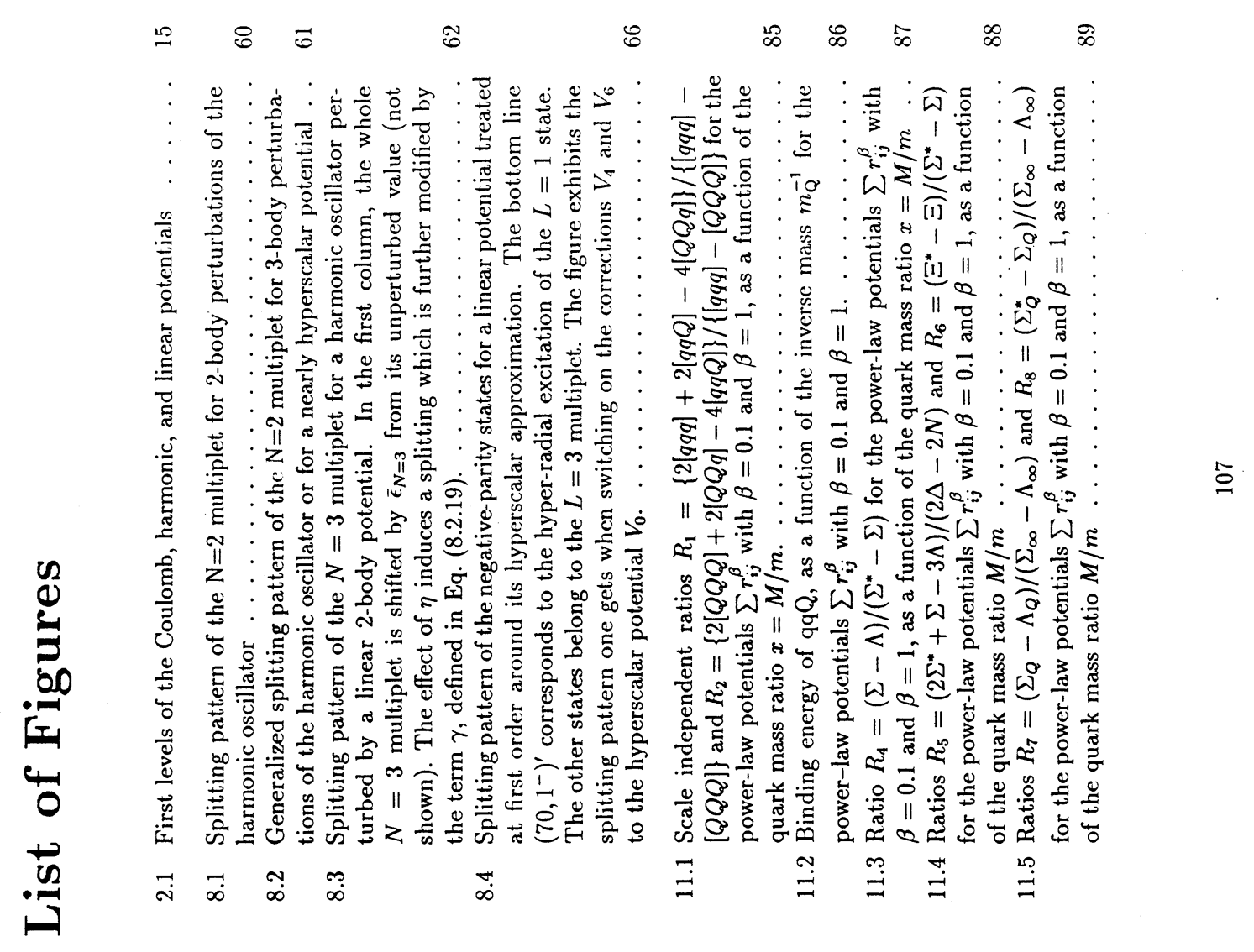




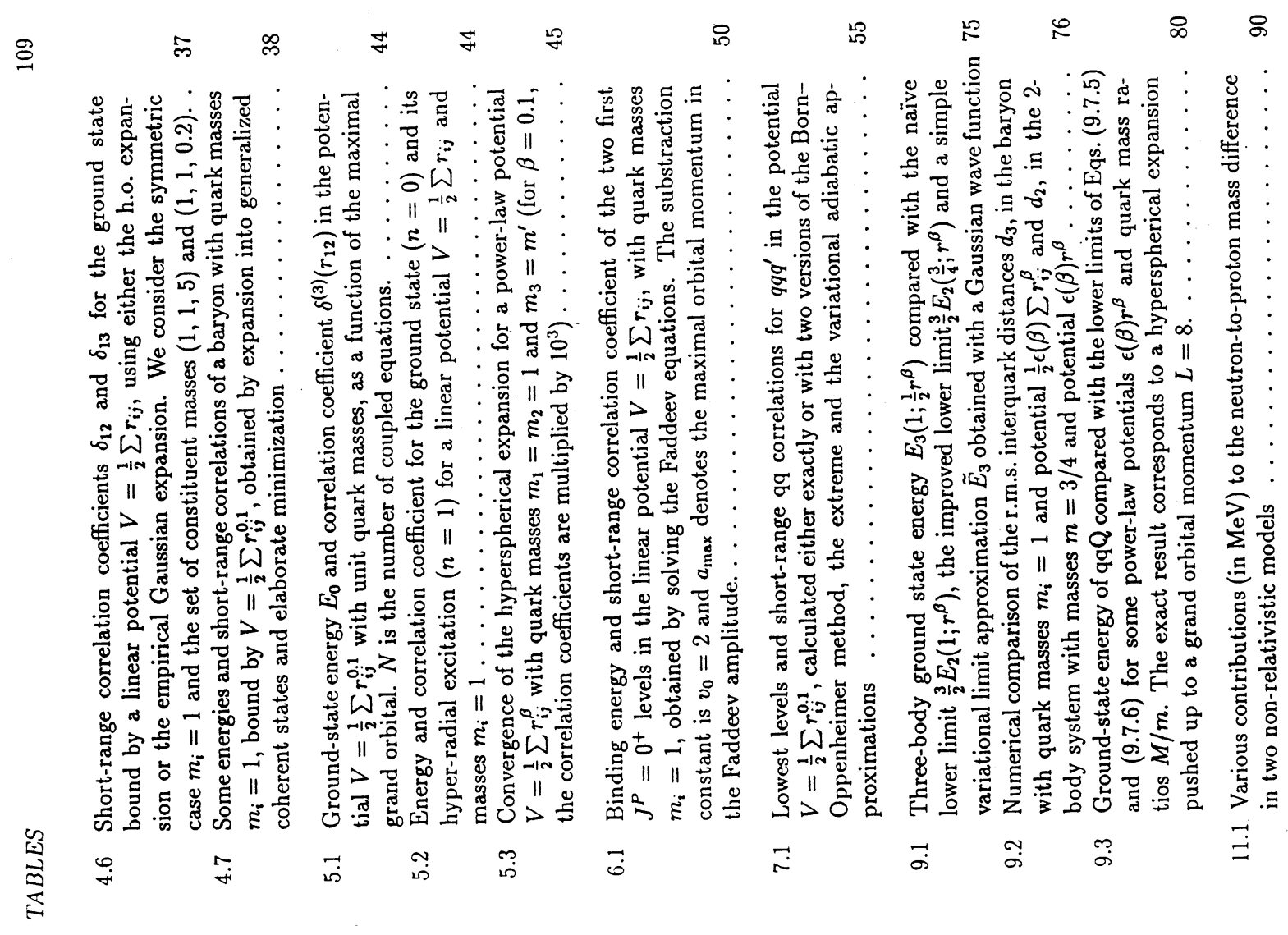

